\title{
AVALIAÇÃO DA LIMPEZA DAS PAREDES DOS CANAIS RADICULARES E DA PERMEABILIDADE DENTINÁRIA, APÓS O USO DA SOLUÇÃO DE EGTA ISOLADAMENTE, OU EM ASSOCIAÇÃO COM TENSOATIVOS.
}

\section{FÁBIO PICOLI}

Tese apresentada à Faculdade de Odontologia de Bauru, da Universidade de São Paulo, como parte dos requisitos para a obtenção do título de Doutor em Odontologia, área de Endodontia. 


\title{
AVALIAÇÃO DA LIMPEZA DAS PAREDES DOS CANAIS RADICULARES E DA PERMEABILIDADE DENTINÁRIA, APÓS O USO DA SOLUÇÃO DE EGTA ISOLADAMENTE, OU EM ASSOCIAÇÃO COM TENSOATIVOS.
}

\section{FÁBIO PICOLI}

\author{
Tese apresentada à Faculdade de \\ Odontologia de Bauru, da Universidade de \\ São Paulo, como parte dos requisitos para a \\ obtenção do título de Doutor em Odontologia, \\ área de Endodontia.
}

Orientador: Prof. Dr. Ivaldo Gomes de Moraes 


\section{Picoli, Fábio}

P587a Avaliação da limpeza das paredes dos canais radiculares e da permeabilidade dentinária, após o uso da solução de EGTA isoladamente, ou em associação com tensoativos / Fábio Picoli. -Bauru, 2007.

138p. : il.; $30 \mathrm{~cm}$

Tese (Doutorado) - Faculdade de Odontologia de Bauru. USP.

Orientador: Prof. Dr. Ivaldo Gomes de Moraes

Aprovado pelo comitê de ética da FOB/USP em 23 de junho de 2004.

(Processo $n^{\circ}$ 53/2004)

Autorizo, exclusivamente para fins acadêmicos e científicos, a reprodução total ou parcial desta dissertação/tese, por processos fotocopiadores e outros meios eletrônicos.

Assinatura: 


\section{Dados Curriculares}

Fábio Picoli

Nascimento

11 de dezembro de 1971

São Paulo - SP.

Filiação

Murilo Picoli e

Marlene Panaggio Picoli.

$1988-1992$

Curso de Graduação em Odontologia Organização Santamarense de Educação e Cultura (OSEC) São Paulo - SP.

$1997-1998$

$1999-2001$

Curso de Pós-Graduação em Odontologia Restauradora (Área de Endodontia) - Nível Mestrado - Faculdade de Odontologia de Ribeirão Preto - Universidade de São Paulo (FORP/USP).

Desde 2001

Professor da Disciplina de Endodontia da Universidade de Franca (UNIFRAN) - SP.

Associações

APCD - Associação Paulista de Cirurgiões Dentistas. 
DEDICATÓRIA 
Aos meus pais, Murilo Picoli e Marlene Panaggio Picoli, à minha irmã e colega de profissão Lara Cristina Picoli, meu reconhecimento e gratidão pelo amor e incansável incentivo para meu crescimento profissional;

Ao meu orientador Prof. Dr. Ivaldo Gomes de Moraes, pela amizade, dedicação e orientação precisa;

dedico este trabalho. 
Primeiramente, a Deus, por ter estado ao meu lado durante a realização deste trabalho e ser uma inesgotável fonte inspiração nos momentos de dificuldade;

A todos os professores que participaram de minha formação na Pós-Graduação, em especial: Prof. Dr. Clóvis Monteiro Bramante, Roberto Brandão Garcia, Norberti Bernardineli, Prof. Dr. Alberto Consolaro, Prof. Dr. José Roberto Pereira Lauris, Prof. Dr. Flávio Augusto Cardoso de Faria, Profa. Dra. Maria Fidela de Lima Navarro, Prof. Dr. José Carlos Pereira e Prof. Dr. Luiz Fernando Pegoraro;

Aos colegas do Doutorado: Everdan, Renato, Ulisses, Fernanda, Rogério, Viviane, Giovana, Graziela e Silvana;

Aos funcionários do Departamento de Endodontia da FOB/USP: Edimauro, Neide, Patrícia e Sueli;

Às funcionárias da Seção de Pós-Graduação e da Biblioteca da FOB;

À FOB/USP e a todos que, direta ou indiretamente, colaboraram para a conclusão deste trabalho;

meus sinceros agradecimentos. 


\section{SUMÁRIO}

RESUMO

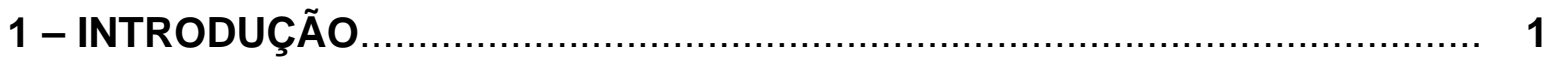

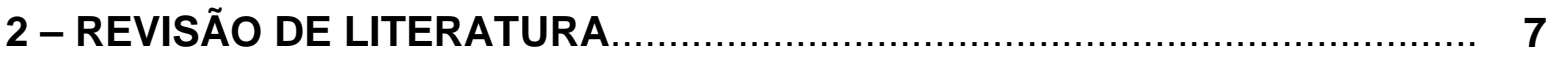

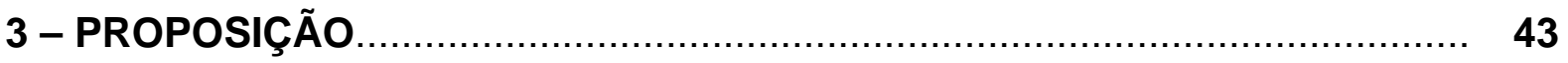

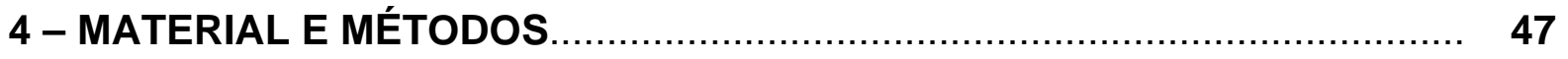

4.1 - Preparo das soluções irrigantes...................................................................... 49

4.2 - Avaliação da capacidade de limpeza das soluções........................................ 50

4.3 - Avaliação da permeabilidade dentinária........................................................ 55

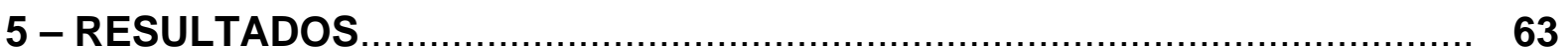

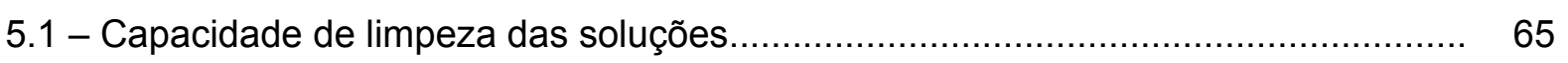

5.2 - Permeabilidade dentinária.......................................................................... 80

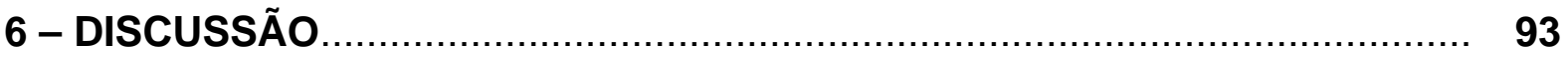

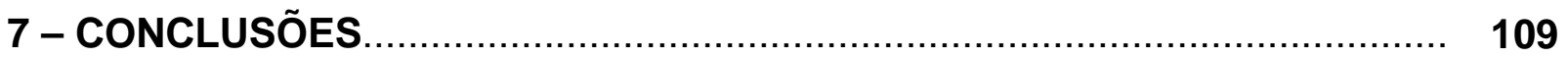

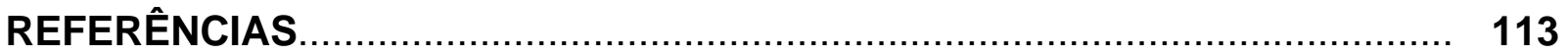

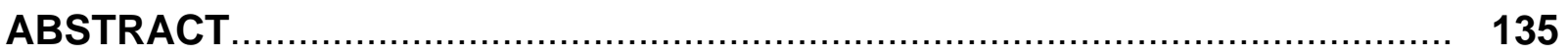




\section{RESUMO}

Objetivou-se avaliar a limpeza das paredes dos canais radiculares instrumentados e a permeabilidade dentinária, após o uso da solução de EGTA isolada ou em associação com tensoativos. Para a análise da capacidade de limpeza, foram usados 25 incisivos centrais superiores humanos, instrumentados pela técnica step-back com limas tipo $\mathrm{K}$ e irrigados com hipoclorito de sódio a $2 \%$. Após a instrumentação, os canais foram irrigados por um período de 5 minutos, com $10 \mathrm{ml}$ das seguintes soluções a serem testadas: Grupo 1- água destilada (controle negativo); Grupo 2 - EGTA a 15\%; Grupo 3 - EGTA-C a 15\%; Grupo 4 - EGTA-T a 15\%; Grupo 5 - EDTA a 17\% (controle positivo). Em seguida, os canais foram lavados com $10 \mathrm{ml}$ de água destilada, secos com cones de papel e as raízes foram fraturadas longitudinalmente e preparadas para microscopia eletrônica de varredura. Uma grade quadriculada, confeccionada digitalmente, foi sobreposta às fotomicrografias, obtidas dos terços cervical, médio e apical dos canais de cada grupo experimental, o que permitiu o cálculo da porcentagem de limpeza da superfície dentinária pela contagem do número de quadrantes limpos. Para a avaliação da permeabilidade dentinária, foram usadas 25 raízes de incisivos centrais superiores humanos instrumentados com as seguintes soluções irrigadoras: Grupo 1 - água destilada (controle negativo); Grupo 2 - EGTA a 15\%; Grupo 3 - EGTA-C a 15\%; Grupo 4 - EGTA-T a 15\%; Grupo 5 - EDTA a 17\%. Foram utilizados $3 \mathrm{ml}$ da solução estudada a cada troca de instrumento. Os canais foram, então, irrigados com $10 \mathrm{ml}$ de água destilada, e secos. A superfície externa das raízes foi impermeabilizada com exceção do ápice e da superfície cervical. Em seguida as raízes foram imersas em sulfato de cobre e, posteriormente, em ácido rubeânico, ambos sob vácuo. Foram, então, obtidos fragmentos dos terços cervical, médio e apical, por meio de cortes transversais das raízes de cada grupo experimental. Estes fragmentos foram fotografados, e a área de penetração dos íons cobre na dentina, evidenciada pela reação com o ácido rubeânico (coloração negra), foi mensurada em computador (programa ImageTool 3.0), o que possibilitou quantificar a permeabilidade dentinária. Os testes estatísticos permitiram concluir que, tanto em 
relação à capacidade de limpeza da superfície dentinária, como em relação à capacidade de promover o aumento da permeabilidade dentinária, as soluções irrigadoras estudadas puderam ser agrupadas em ordem decrescente do seguinte modo: EDTA, EGTA-T, EGTA-C, EGTA, Água destilada. A adição de tensoativos à solução de EGTA resultou em uma melhora de sua capacidade de limpeza da superfície dentinária e no aumento da permeabilidade da dentina. Apenas a solução de EGTA-T a 15\% apresentou resultados estatisticamente semelhantes à solução de EDTA a $17 \%$, tanto em relação à limpeza, quanto à permeabilidade da dentina. Houve uma correlação diretamente proporcional entre os resultados obtidos nos dois experimentos realizados: quanto maior a capacidade de limpeza promovida pela solução quelante estudada, maior a permeabilidade da dentina das paredes do canal.

Palavras-chave: Soluções irrigantes. Limpeza dentinária. Permeabilidade dentinária. Endodontia. 
1 - INTRODUCÃO 


\section{1 - INTRODUÇÃO}

Durante a fase de preparo, além da limpeza proporcionada pela ação mecânica dos instrumentos endodônticos nas paredes dentinárias do canal radicular, é necessário o emprego de soluções químicas auxiliares, que possam facilitar a atuação desses instrumentos, além de realizar a limpeza e desinfecção de regiões do canal, inacessíveis aos mesmos, como as regiões de istmos e ramificações.

A solução irrigadora ideal deve possuir, entre outras propriedades, a capacidade de dissolução de restos de tecido pulpar e de promover a eliminação de microrganismos presentes no sistema de canais radiculares sem, entretanto, agredir os tecidos periapicais (ZEHNDER ${ }^{189}, 2006$ ). A literatura tem evidenciado que a solução de hipoclorito de sódio preenche satisfatoriamente os dois primeiros requisitos por apresentar uma boa capacidade de dissolução tecidual (HAND; SMITH; HARRISON ${ }^{77}, 1978$, THÉ ${ }^{172}, 1979$, KOSKINEN; STENVALL; UITTO ${ }^{87}, 1980$, MOORER; WESSELINK ${ }^{104}$, 1982) e um bom efeito antimicrobiano (SHIH; MARSHALL; ROSEN ${ }^{156}, 1970$, BLOOMFIELD; MILES ${ }^{17}, 1979$, FOLEY et al. ${ }^{55}, 1983$, BYSTRÖM; SUNDQVIST ${ }^{23}, 1985$ ) em concentrações superiores a $0,5 \%$. Porém, sua biocompatibilidade está longe da ideal, sendo que sua citotoxicidade está diretamente relacionada com a concentração utilizada (THÉ; MALTHA; PLASSCHAERT ${ }^{173}, 1980$, LAMERS; VAN MULLEM; SIMON $\left.{ }^{89}, 1980\right)$.

Entretanto, a partir de 1975, com a introdução da microscopia eletrônica de varredura na pesquisa endodôntica, observou-se que as técnicas e instrumentos utilizados na realização do preparo do canal produzem paredes dentinárias recobertas por resíduos orgânicos e inorgânicos (McCOMB; SMITH ${ }^{101}$, 1975). Essa camada de resíduos tem sido chamada de smear layer.

A smear layer é resultado direto de procedimentos que envolvem o corte da dentina. Sua espessura é variável, geralmente em torno de $1 \mu \mathrm{m}$ à $2 \mu \mathrm{m}$, podendo ser encontrada no interior dos túbulos dentinários, a uma profundidade de até $40 \mu \mathrm{m}$ (MADER; BAUMGARTNER; PETERS ${ }^{96}$, 1984). Fazem parte de sua composição 
raspas de dentina, fragmentos de tecido pulpar, material necrótico e, até mesmo, microrganismos (PASHLEY ${ }^{119}, 1992$ ).

Inúmeros trabalhos têm demonstrado que a smear layer interfere na ação desinfectante das soluções irrigantes e das medicações intracanais, age como uma barreira física impedindo a penetração dos cimentos endodônticos nos túbulos dentinários, prejudicando a adesão dos cimentos às paredes do canal radicular $\mathrm{e}$ afetando a eficiência de selamento da obturação (McCOMB; SMITH ${ }^{101}, 1975$, WHITE; GOLDMAN; LIN ${ }^{185}$, 1984, WHITE; GOLDMAN; LIN ${ }^{186}$, 1987, SEN; WESSELINK; TÜRKÜN ${ }^{152}$, 1995, BERHREND; CUTLER; GUTMANN ${ }^{15}$, 1996).

Apesar das propriedades desejáveis da solução de hipoclorito de sódio sobre o componente orgânico dos canais radiculares, estudos por meio de microscopia eletrônica de varredura têm demonstrado que a mesma é ineficaz em promover a eliminação da porção inorgânica da smear layer (BAKER, et al. ${ }^{10}, 1975$, McCOMB; SMITH $^{101}$, 1975, McCOMB; SMITH; BEAGRIE ${ }^{102}$, 1976, BOLANOS; JENSEN ${ }^{18}$, 1980, GOLDMAN et al. ${ }^{68}, 1981$, GOLDMAN et al. ${ }^{69}, 1982$, BRANCINI; BRAMANTE; BERBERT $^{19}$, 1983, CIUCCHI; KHETTABI; HOLZ ${ }^{33}, 1989$, GAVINI $^{63}, 1992$, GAVINI $^{64}$, 1994, GARBEROGLIO; BECCE ${ }^{61}, 1994$, SOUZA et al. ${ }^{162}$, 2003).

Com o objetivo de remover a smear layer formada durante o preparo dos canais, vários métodos têm sido propostos, dentre eles, o uso de ácidos orgânicos como o ácido cítrico e o lático (TIDMARSH ${ }^{174}, 1978$, WAYMAN et al. ${ }^{183}, 1979$ ), de agentes quelantes como a solução de EDTA (GOLDBERG; ABRAMOVICH ${ }^{66}, 1977$, YAMADA et al. ${ }^{188}, 1983$, HÜLSMANN; HECKENDORFF; LENNON $\left.{ }^{81}, 2003\right)$ e, mais recentemente, o uso de derivados da tetraciclina (BARKHORDAR et al. ${ }^{12}, 1997$, HAZNEDAROGLU; ERSEV ${ }^{80}$, 2001, TORABINEJAD et al. ${ }^{177}$, 2003) e, do laser (TAKEDA et al. $^{166}$, 1998, TAKEDA, et al. ${ }^{167}$, 1999, GUERISOLI ${ }^{72}, 2002$ ). Provavelmente, o método mais empregado na atualidade, devido ao seu baixo custo e aos resultados obtidos, seja a utilização da solução quelante de EDTA, após a instrumentação, para a limpeza final do canal, ou alternadamente com a solução de hipoclorito de sódio, durante a instrumentação (GOLDMAN et al. ${ }^{69}, 1982$ ).

A solução de EDTA (ácido etilenodiaminotetracético) foi introduzida na endodontia em 1957, por $\varnothing S$ TBY $^{115}$, para instrumentação de canais em substituição 
aos ácidos inorgânicos até então utilizados, devido à sua ação quelante e por ser menos irritante.

Estudos posteriores têm demonstrado que a solução de EDTA apresenta, também, capacidade de reduzir a microdureza da dentina radicular (SAQUY ${ }^{144}$, 1991, CRUZ FILHO ${ }^{37}$, 1994, FAIRBANKS ${ }^{49}$, 1995, CRUZ FILHO ${ }^{38}$, 1998), facilitando a ação mecânica dos instrumentos, principalmente em canais atrésicos, e ainda, é capaz de promover o aumento da permeabilidade dentinária (PÉCORA ${ }^{122}, 1985$, ZUOLO et al. ${ }^{192}$, 1987), possibilitando uma melhor ação de substâncias medicamentosas no interior dos túbulos dentinários infectados (BYSTRÖM; SUNDQVIST ${ }^{23}$, 1985).

Recentemente, soluções quelantes alternativas ao EDTA têm sido propostas em endodontia, como a solução de CDTA (CRUZ FILHO ${ }^{38}$, 1998, GUERISOLI ${ }^{72}$, 2002, SOUSA-NETO et al. ${ }^{161}$, 2002, SOUZA et al. ${ }^{162}$, 2003) e de EGTA (CRUZ FILHO $^{38}$, 1998, SOUZA ${ }^{163}$, 1999, ÇALT; SERPER ${ }^{24}, 2000$, GUERISOLI $^{72}, 2002$, SOUSA-NETO et al. ${ }^{161}$, 2002, CRUZ FILHO et al. $^{39}$, 2002, SOARES; SOUSA ${ }^{160}$, 2003, SOUZA et al. ${ }^{162}$, 2003, VISWANATH; HEGDE; MUNSHI ${ }^{179}$, 2003).

Trabalhos na literatura têm demonstrado que a solução de EGTA apresenta uma maior especificidade para quelar íons cálcio que a solução de EDTA (CRUZ FILHO et al. ${ }^{39}$, 2002) sendo, inclusive, utilizada na medicina para obtenção de meios isentos de cálcio (CARINI et al. ${ }^{28}, 1997$, LOVIK et al. ${ }^{95}, 2001$ ). A solução de EGTA é, ainda, capaz de reduzir a microdureza da dentina radicular (CRUZ FILHO et al. ${ }^{39}$, 2002) e remover smear layer intracanal sem provocar a erosão da superfície dentinária tratada (ÇALT; SERPER ${ }^{24}, 2000$, VISWANATH; HEGDE; MUNSHI ${ }^{179}$, 2003).

Todavia, atualmente, sabe-se muito pouco sobre a solução de EGTA, qual seria a sua concentração clínica ideal para ser utilizada intracanal, se seria capaz de aumentar a permeabilidade da dentina radicular e se a adição de tensoativos resultaria em uma melhora de sua capacidade de limpeza e propriedade quelante. 
2 - REVISÃO DE LITERATURA 


\section{2 - REVISÃO DE LITERATURA}

NIKIFORUK; SREEBNY ${ }^{112}$, em 1953, estudaram a ação do ácido etilenodiaminotetracético (EDTA) como agente desmineralizador de tecido duro. Inspirado neste trabalho, ØSTBY ${ }^{115}$, em 1957, preconizou o emprego do EDTA na instrumentação de canais radiculares em substituição aos ácidos inorgânicos até então utilizados, devido a sua ação quelante e por ser menos irritante para os tecidos. A solução de EDTA preconizada apresentava como composição: EDTA 15\% e hidróxido de sódio ( $\mathrm{pH} \cong 7,3$ ).

Em relação à permeabilidade dentinária, MARSHALL; MASSLER; DUTE ${ }^{98}$, em 1960, avaliaram esta propriedade da dentina pelo emprego de radio-isótopos $\left(\mathrm{S}^{35}, \mathrm{Na}^{22}, \mathrm{I}^{131}, \mathrm{P}^{32}\right)$. Os canais foram divididos em quatro grupos para receberem os seguintes tratamentos. No grupo 1 (controle), os canais não foram instrumentados, tendo somente a polpa removida por meio de extirpa-nervos. No grupo 2, os canais foram instrumentados utilizando-se água, como solução irrigadora. No grupo 3, os canais foram instrumentados utilizando-se, para irrigação, EDTA, soda clorada a $5,25 \%$ alternada com água oxigenada a $3 \%$, nitrato de prata amoniacal e solução aquosa de ácido sulfúrico neutralizada, após 1 minuto de ação, com bicarbonato de sódio. E, finalmente, no grupo 4, os canais foram instrumentados utilizando-se água oxigenada a 3\%, soda clorada a 5,25\%, nitrato de prata amoniacal, ácido sulfúrico e eugenol. Os autores formularam um índice de permeabilidade dentinária para fornecer parâmetros para a avaliação matemática dos níveis de permeabilidade das paredes dentinárias dos canais radiculares. Os resultados obtidos evidenciaram que as regiões cervical e média dos canais foram mais permeáveis que a região apical, frente a todos os radio-isótopos empregados.

ANDERSON; RONNING ${ }^{4}$, em 1962, avaliaram a permeabilidade da dentina coronária em dentes submetidos ao corte da coroa por instrumentos rotatórios ou fratura da mesma. Os autores verificaram uma menor penetração do corante nos dentes submetidos ao corte que naqueles submetidos à fratura, evidenciando que a presença de debris, nos fragmentos submetidos ao corte por instrumentos rotatórios, impediu uma maior penetração do corante nos túbulos dentinários. 
Com o objetivo de reduzir a tensão superfícial da solução de EDTA, FEHR; $\varnothing S T B Y^{50}$, em 1963, recomendaram a associação de Cetlavon, um tensoativo catiônico derivado do amônio quaternário. Esses autores observaram que a magnitude de desmineralização promovida pela solução de EDTAC foi proporcional ao tempo de sua aplicação. Quando aplicado sobre a dentina, por 5 minutos, desmineralizava uma camada de 20 a 30 micrometros. A área de dentina atingida pela solução de EDTAC apresentava-se bem definida e regular, demonstrando um poder autolimitante desta solução.

Baseado no fato da tensão superficial ser um dos mais importantes fatores que determinam o poder de umectação de uma determinada substância, NAUMOVICH ${ }^{111}$, em 1963, estudou esta propriedade em vinte drogas utilizadas na terapêutica endodôntica, constatando que o EDTA apresentava uma tensão superficial de 54,0 dinas $/ \mathrm{cm}$. Quando foi adicionado um tensoativo catiônico (Cetavlon) à solução de EDTA, sua tensão superficial caiu para 39,7 dinas/cm.

PATTERSON $^{121}$, em 1963, avaliou o efeito do EDTA e do EDTAC sobre a microdureza da dentina, utilizando o teste de dureza Knoop, verificando que a superfície dentinária tratada tinha sua microdureza reduzida após a aplicação do EDTAC e que esta solução era mais eficaz que a solução de EDTA.

WEINREB; MEIER ${ }^{184}$, em 1965, verificaram que a solução de EDTAC facilitava o preparo de canais radiculares atrésicos, mas sugeriram que fosse realizada a irrigação com um volume abundante, renovando-se freqüentemente esta solução, para que a mesma fosse quimicamente efetiva. Estes autores observaram que, quando se realizava a troca freqüente, esta solução apresentava-se mais efetiva.

STEWART; KAPSIMALAS; RAPPAPORT ${ }^{165}$, em 1969, com o intuito de promover o aumento da permeabilidade da dentina, para que substâncias químicas penetrem nos túbulos dentinários, recomendaram o emprego do RC-Prep, um creme composto por peróxido de uréia a 10\%, EDTA a 15\% e carbowax, utilizado em associação com o hipoclorito de sódio a $5 \%$. Os autores verificaram que, após o seu uso em canais contaminados, foram obtidos $97,2 \%$ de culturas negativas na primeira sessão e 94,4\%, na segunda. 
COHEN; STEWART; LASTER ${ }^{35}$, em 1970, avaliaram a permeabilidade dentinária resultante do uso de diversas substâncias químicas auxiliares da instrumentação de canais radiculares e observaram que, o RC-Prep, associado à soda clorada, foi capaz de promover um aumento significativo da permeabilidade dentinária, nos terços médio e apical das raízes dos dentes estudados.

Utilizando microscopia eletrônica de varredura, FROMME; GUTTZEIT; RIEDEL $^{58}$, em 1970, observaram a limpeza e alisamento da superfície dentinária, quando foi empregada a solução de EDTA. Esses autores também demonstraram uma redução da dureza da dentina promovida por esta solução em áreas volumosas dos canais radiculares, porém, não observaram o mesmo em áreas estreitas.

ROBAZZA ${ }^{141}$, em 1973, estudou as alterações na permeabilidade dentinária promovidas após o uso de algumas substâncias químicas auxiliares da instrumentação de canais radiculares. Empregando-se o azul de metileno para evidenciação da permeabilidade, o autor pôde concluir que o Endo-PTC, em combinação com o Líquido de Dakin, proporcionou o maior aumento da permeabilidade, dentre as substâncias auxiliares avaliadas.

BAKER et al. ${ }^{10}$, em 1975, por meio de microscopia eletrônica de varredura, observaram que os agentes quelantes alteravam a morfologia normal dos túbulos dentinários. Segundo os autores, estas alterações eram devidas, provavelmente, a diferenças na mineralização da dentina intertubular e peritubular. Esta última, sendo mais densa, proporcionava maior resistência a alterações morfológicas provocadas pelos agentes quelantes.

Já McCOMB; SMITH ${ }^{101}$, em 1975, avaliaram, in vitro, por meio de microscopia eletrônica de varredura, os efeitos de diferentes técnicas de instrumentação e soluções irrigantes utilizadas no preparo dos canais radiculares, e observaram que, após a instrumentação, independentemente da técnica ou do instrumento utilizado, os túbulos dentinários encontravam-se completamente obscurecidos por uma camada de resíduos (smear layer). A separação desta camada em algumas áreas do canal indicou que a mesma não se encontrava firmemente aderida à dentina subjacente. Os resultados demonstraram que nenhuma técnica de irrigação foi capaz de remover completamente a smear layer das paredes dos canais radiculares. 
O produto comercial REDTA, quando utilizado como solução irrigante, produziu paredes dentinárias mais limpas.

Em 1976, McCOMB; SMITH; BEAGRIE ${ }^{102}$, complementando o estudo realizado por McCOMB e $\mathrm{SMITH}^{101}$ no ano anterior, realizaram um estudo in vivo onde utilizaram microscopia eletrônica de varredura para avaliar as paredes de canais radiculares preparados com o auxílio de diferentes soluções irrigantes. Os resultados encontrados foram similares aos observados previamente in vitro. $\mathrm{O}$ uso da solução de EDTA produziu paredes dentinárias mais limpas.

MOODNICK et al. ${ }^{103}$, em 1976, avaliaram, comparativamente, canais instrumentados com limas tipo K e Hedströen, empregando como substâncias auxiliares da instrumentação, a solução salina e o hipoclorito de sódio a 2,5\%, e verificaram não haver diferença quanto ao grau de limpeza conseguido. O exame das fotomicrografias, obtidas por meio de microscopia eletrônica de varredura, evidenciou que as paredes dos canais radiculares apresentavam muitas irregularidades que permitiram o aprisionamento de resíduos e tecido pulpar não removido pela ação dos instrumentos endodônticos, durante o preparo.

FRASER; LAWS ${ }^{56}$, em 1976, estudando a ação do EDTA sobre a permeabilidade dentinária, constataram que as regiões cervical e média do canal radicular sofriam ação quelante desta solução, mas a dentina apical permanecia inalterada.

$\mathrm{RAM}^{139}$, em 1977, constatou que a remoção de resíduos dos canais radiculares depende mais do diâmetro dos canais e das cânulas de irrigação, que do tipo de solução empregada.

GOLDBERG; ABRAMOVICH ${ }^{66}$, em 1977, estudaram in vitro, a ação do EDTAC sobre as paredes dentinárias do canal radicular com o auxílio de um microscópio eletrônico de varredura, e verificaram que essas paredes, após a instrumentação, apresentavam uma textura lisa e os túbulos dentinários um aspecto circular e regular, com grande parte da camada superficial de resíduos tendo sido eliminada.

KAUFMAN et al. ${ }^{85}$, em 1978, avaliaram a capacidade de limpeza da solução de EDTA-C e do Salvizol, por meio de microscopia eletrônica de varredura. Os autores puderam constatar que a solução de EDTA-C foi capaz de limpar 
satisfatoriamente as paredes dos canais radiculares, embora não atuasse sobre os restos orgânicos do tecido pulpar, enquanto que o Salvizol foi capaz de promover a dissolução do componente orgânico e inorgânico da dentina.

BOLANOS; JENSEN ${ }^{18}$, em 1980, estudaram a capacidade de limpeza promovida pelas técnicas telescópica e convencional de instrumentação, empregando-se substâncias químicas auxiliares distintas: soro fisiológico, hipoclorito de sódio a $1 \%$ ou RC-Prep. A análise por microscopia eletrônica de varredura evidenciou que, independente da técnica e da substância auxiliar utilizada, todas as regiões do canal em que o instrumento havia atuado, apresentavam acúmulo de smear layer obstruindo os túbulos dentinários.

GOLDMAN et al. ${ }^{68}$, em 1981, por meio de microscopia eletrônica de varredura, avaliaram diversas soluções propostas para irrigação final dos canais radiculares: o hipoclorito de sódio a $5,25 \%$, o REDTA $^{\circledR}$ e a substância TEGO ${ }^{\circledR}$. Os resultados obtidos demonstraram que o REDTA foi a única solução capaz de remover a smear layer das paredes dos canais radiculares.

CURY; BRAGOTTO; VALDRIGHI ${ }^{41}$, em 1981, estudaram a influência do pH no poder de desmineralização do EDTA. Por meio da trituração de dentes humanos, foi obtido pó de dentina, o qual foi submetido à ação do EDTA em pH 5, 6, 7, 8 ou 9. Após a análise colorimétrica das amostras, os autores concluíram que um maior poder de desmineralização da solução de EDTA foi conseguido com o pH entre 5 e 6.

GOLDBERG; SPIELBERG ${ }^{67}$, em 1982, estudaram a capacidade de limpeza da solução de EDTA, por meio de microscopia eletrônica de varredura. Os autores ressaltaram que a obtenção de uma superfície dentinária livre de smear layer facilitaria a penetração de agentes antimicrobianos no interior dos túbulos dentinários, assim como do material obturador.

YAMADA et al. ${ }^{188}$, em 1983, por meio de microscopia eletrônica de varredura, compararam a eficácia de diferentes volumes de diversas soluções irrigantes, como a solução salina, hipoclorito de sódio a 5,25\%, o EDTA a $17 \%$ e a $8,5 \%$ e o ácido cítrico a $25 \%$, usadas como auxiliares da instrumentação de canais. Os resultados revelaram que a associação de $10 \mathrm{ml}$ de EDTA a 17\% com 10ml de hipoclorito de sódio à $5,25 \%$ foi mais efetiva na remoção da smear layer. 
BRANCINI; BRAMANTE; BERBERT ${ }^{19}$, em 1983, analisaram a capacidade de limpeza de algumas soluções irrigantes, com o auxilio da microscopia eletrônica de varredura. Os resultados demonstraram que a eficiência de limpeza das soluções irrigantes obedeceu a seguinte ordem decrescente: EDTA, ácido cítrico, Dehyquart A, Tergentol e líquido de Dakin.

CAMERON $^{26}$, em 1983, estudou a smear layer e sugeriu que esta é composta por duas porções: uma superficial e fracamente aderida à parede do canal e outra, mais profunda, obstruindo os túbulos dentinários.

Com o auxílio de um microscópio eletrônico de varredura, MADER; BAUMGARTNER; PETERS ${ }^{96}$, em 1984, investigaram as características morfológicas da smear layer encontrada em paredes de canais radiculares instrumentados com limas tipo $\mathrm{K}$ e irrigados com hipoclorito de sódio a 5,25\%. Os autores observaram que a smear layer consistia basicamente de uma camada de resíduos que recobria a parede do canal radicular, apresentando 1 a $2 \mu \mathrm{m}$ de espessura e resíduos que foram compactados no interior dos túbulos dentinários durante a instrumentação, chamados de smear plugs, podendo chegar a $40 \mu \mathrm{m}$ de profundidade.

DIPPEL; BORGGREVEN; HOPPENBROUWERS ${ }^{46}$, em 1984, afirmaram que a permeabilidade dentinária decresce por volta de $35 \%$, com a presença da smear layer.

BAUMGARTNER et al. $^{13}$, em 1984, avaliaram, por meio de microscopia eletrônica de varredura, a limpeza das paredes dos canais radiculares instrumentados, utilizando-se o soro fisiológico, o hipoclorito de sódio a 5,25\% e o ácido cítrico a $50 \%$, associados ou não entre si. Os autores verificaram que o uso do ácido cítrico como solução irrigante final, em associação ou não com o hipoclorito de sódio a 5,25\%, promoveu uma melhor remoção da smear layer das paredes dos canais.

BYSTRÖM; SUNDQVIST ${ }^{23}$, em 1985, demonstraram, in vivo, que a ação antimicrobiana da solução de hipoclorito de sódio a $5 \%$ foi aumentada pela remoção da smear layer das paredes dos canais radiculares, com a utilização da solução de EDTA.

Por meio de um método histoquímico, PÉCORA ${ }^{122}$, em 1985, avaliou a permeablidade da dentina radicular, após o preparo manual dos canais radiculares 
com a utilização das seguintes soluções irrigantes: liquido de Dakin, solução de Milton, soda clorada, soda clorada alternada com peróxido de hidrogênio, EDTA, RC-Prep mais soda clorada, Tergentol-Furacin, Endo-PTC e água como controle. Os resultados evidenciaram que as soluções halogenadas e a de EDTA foram as que mais aumentaram a permeabilidade da dentina radicular.

$\mathrm{AUN}^{7}$, em 1985, investigou, por meio de microscopia eletrônica de varredura, a capacidade de limpeza de limas tipo $\mathrm{K}$ e K-Flex, em função do número de utilizações. Os resultados da contagem dos túbulos visíveis, nas fotomicrografias obtidas, demonstraram que o tipo de instrumento e o número de utilizações influenciou diretamente na limpeza da parede dos canais instrumentados. A lima tipo K-Flex, por apresentar uma área de escape maior, propiciou paredes dentinárias mais limpas. A perda do poder de corte dos instrumentos, resultado do seu uso sucessivo, levou a uma menor formação de smear layer.

BAUMGARTNER; MADER ${ }^{14}$, em 1987, estudaram a capacidade de limpeza promovida pelo uso do hipoclorito de sódio a 5,25\% e do EDTA a 15\%, empregados isoladamente ou em associação como soluções irrigantes finais, após o preparo dos canais radiculares utilizando-se solução salina a 0,9\%. Os resultados demonstraram que o uso alternado do hipoclorito de sódio a 5,25\% com o EDTA a 15\%, promoveu a completa remoção da smear layer e dos remanescentes pulpares, das paredes dos canais instrumentados.

ROBAZZA et al. ${ }^{142}$, em 1987, compararam o uso do Endo-PTC associado ao Líquido de Dakin, com o uso do RC-Prep associado à soda clorada e verificou que o Endo-PTC com o Líquido de Dakin promoveu um aumento mais uniforme da permeabilidade dentinária radicular, quando comparado ao RC-Prep associado à soda clorada. Os autores constataram, também, que quanto maior o número de instrumentos utilizados, maior era o aumento da permeabilidade dentinária, independente da substância química auxiliar utilizada.

Em 1987, PÉCORA et al. ${ }^{125}$ apresentaram um método histoquímico para o estudo da permeabilidade dentinária radicular que permitia a montagem de fragmentos radiculares em lâminas para serem observadas em microscópio. Os autores avaliaram 11 soluções auxiliares da instrumentação de canais radiculares e observaram que o aumento mais significativo da permeabilidade da dentina radicular 
foi obtido com as soluções de hipoclorito de sódio a $5 \%$, hipoclorito de sódio a $0,5 \%$ (Dakin), hipoclorito de sódio a $1 \%$ (Milton), hipoclorito de sódio a $5 \%$ e $\mathrm{H}_{2} \mathrm{O}_{2}$ a $3 \%$, alternadamente e, EDTA a $17 \%$.

ZUOLO et al. ${ }^{192}$, em 1987, estudaram, por meio de um método histoquímico, o efeito do EDTA e de suas associações com tensoativos aniônicos e catiônicos sobre a permeablidade dentinária, e observaram que a solução de EDTA, associada com um tensoativo catiônico (EDTAC), era mais efetiva na promoção do aumento da permeabilidade da dentina radicular.

GUIMARÃES et al. ${ }^{74}$, em 1988, avaliaram a tensão superficial de várias soluções auxiliares da instrumentação dos canais radiculares, pelo método de ascensão capilar, e observaram que a adição de tensoativos à solução de EDTA reduzia sensivelmente sua tensão superficial. A solução de EDTA proposta originalmente por $\varnothing$ STBY (1957) apresentava tensão superficial de 69,25 dinas/cm e a adicão de $0,1 \%$ de Cetavlon fez com que esta tensão superficial caísse para 33,92 dinas/cm. O Lauril sulfato de sódio a $0,1 \%$ apresentou a menor tensão superficial dentre as soluções estudadas. Os autores sugeriram que todas as soluções irrigadoras aquosas deveriam apresentar em sua composição, um tensoativo para uma maior eficiência e uma rápida atuação.

MOURA et al. ${ }^{108}$, em 1988, analisaram in vitro a permeabilidade dentinária radicular em dentes instrumentados com e sem o uso final do EDTA-C, por meio do cálculo da porcentagem de penetração do corante azul de metileno, na dentina radicular de dentes humanos extraídos. Durante a instrumentação, foi utilizado como substância química auxiliar, o creme Endo-PTC associado ao hipoclorito de sódio a $1 \%$. Finalizada a instrumentação, o canal recebeu irrigação com a solução de tergentol-furacin, seguida ou não do emprego final do EDTA-C. O autor constatou que não houve diferença estatisticamente significante em relação à permeabilidade dentinária, frente ao uso ou não do EDTA-C, ao final do preparo do canal radicular.

PAIVA; ANTONIAZZI ${ }^{117}$, em 1988, afirmaram que a maior concentração da smear layer, na porção apical dos canais radiculares instrumentados, pode ser facilmente explicada pelas condições anatômicas próprias desta região, onde o instrumento endodôntico tem um maior contato com a parede do canal e a substância auxiliar tem maior dificuldade de penetração para sua atuação. 
PROKOPOWITSCH; MOURA; MUENCH ${ }^{135}$, em 1989, analisaram em dentes humanos extraídos, a permeabilidade dentinária radicular do terço apical, tendo como fonte de variação a solução irrigadora utilizada na instrumentação dos canais radiculares (soro fisiológico; tergentol-furacin; hipoclorito de sódio a 1\%; Endo PTC neutralizado pelo hipoclorito de sódio a $1 \%$, seguido de irrigação final com tergentolfuracin; EDTA-T a 17\%). Por meio da porcentagem de penetração dentinária do corante azul de metileno, observada em microscópio comparador, os autores puderam verificar que a solução que menos atuou na região apical, quanto à capacidade de aumentar a permeabilidade da dentina, foi o soro fisiológico. Não houve diferença estatisticamente significante entre as médias obtidas nos grupos tratados com EDTA-T e tergentol-furacin, assim como entre o grupo do EDTA-T e do Endo-PTC. O creme Endo-PTC neutralizado pelo hipoclorito de sódio a $1 \%$ foi o que melhor promoveu um aumento na permeabilidade dentinária no terço apical dos canais radiculares.

MOURA; PAIVA ${ }^{107}$, em 1989, analisaram in vitro a permeabilidade da dentina radicular em função do instrumento utilizado (Tipo $\mathrm{K}$ ou K-Flex) e do número de utilizações deste instrumento. Por meio do cálculo da porcentagem de penetração do corante azul de metileno na dentina, os autores puderam concluir que não houve influência do tipo de instrumento utilizado na permeabilidade dentinária, porém, o aumento no número de utilizações do instrumento, diminuiu a porcentagem de penetração do corante, principalmente na região apical.

CIUCCHI; KHETTABI; HOLZ ${ }^{33}$, em 1989, compararam a efetividade de diferentes procedimentos de irrigação na remoção da smear layer das paredes de canais radiculares. A microscopia eletrônica de varredura revelou que os canais que receberam irrigação final com $\mathrm{NaOCl}$ apresentavam superfícies cobertas com smear layer, enquanto que a solução de EDTA produziu paredes quase que completamente livres de smear layer.

FOGEL; PASHLEY ${ }^{54}$, em 1990, afirmaram que apresença da smear layer pode afetar a permeabilidade dentinária.

AUN; PAIVA; ANTONIAZZI ${ }^{9}$, em 1990, avaliaram, por meio da microscopia eletrônica de varredura, a limpeza das paredes dos canais radiculares, ao nível do terço apical, após o preparo químico-mecânico, tendo como fonte de variação, o tipo 
e o número de utilizações dos instrumentos. Os resultados demonstraram que, quanto maior o número de utilizações, independente do instrumento utilizado (lima tipo $\mathrm{K}$ ou K-Flex), maior o número de canalículos visíveis. Segundo os autores, a redução na eficiência de corte do instrumento, que surge com o aumento no número de utilizações, resulta na formação de uma menor quantidade de smear layer.

$\mathrm{AUN}^{8}$, em 1990, relatou não ter evidenciado nenhuma vantagem ou benefício na manutenção da smear layer aderida à parede do canal radicular.

PÉCORA et al. ${ }^{127}$, em 1990, apresentaram um método histoquímico para detectar a ação quelante do EDTA na dentina radicular, adaptando o método de FEIGL (1958). Os dentes foram imersos em uma solução de sulfato de níquel a 5 \% durante 30 minutos. Após serem secos, foram divididos em dois grupos: no Grupo 1 (controle), os dentes eram imersos em um recipiente contendo uma solução alcoólica de dimetilglioxima a 1,0\%; no Grupo 2 (experimental), os dentes eram imersos em uma solução de EDTA por 30 minutos e, em seguida, em uma solução de dimetilglioxima. Finalizada esta etapa, os dentes de ambos os grupos eram removidos do recipiente e secos, para serem seccionados transversalmente de milímetro em milímetro. Esta metodologia possibilitou aos autores concluírem que a solução de EDTA penetra no interior dos canalículos dentinários quelando ions de níquel, podendo ser revelado pela reação níquel-dimetilglioxima.

SILVA et al. ${ }^{158}$, em 1990, verificaram in vitro a influência da instrumentação ultra-sônica, quando comparada à instrumentação manual, na permeabilidade dentinária radicular de pré-molares superiores humanos. Para quantificar a permeabilidade, os autores utilizaram um método histoquímico semelhante ao proposto por PÉCORA et al. ${ }^{125}$, em 1987. Os resultados demonstraram um melhor desempenho com a instrumentação ultra-sônica, sem diferença estatística entre os terços radiculares analisados. Nos canais vestibulares, verificou-se uma permeabilidade significativamente maior que nos palatinos.

MAIA ${ }^{97}$, em 1991, avaliou a capacidade do hipoclorito de sódio, do ácido cítrico e do EDTA, em promover o aumento da permeabilidade dentinária. A penetração do corante Rodamina B na dentina serviu para evidenciar o aumento da permeabilidade. Os resultados permitiram à autora concluir que o EDTA foi a 
solução que apresentou, estatisticamente, o melhor desempenho quanto à capacidade de aumentar a permeabilidade da dentina apical.

SAQUY ${ }^{144}$, em 1991, avaliou a capacidade quelante do EDTA isoladamente ou associado ao líquido de Dakin, por meio de métodos químicos e da análise da microdureza da dentina, constatando que, tanto a solução de EDTA como a sua associação com o líquido de Dakin são efetivas em quelar ions cálcio, demonstrando que a ação quelante do EDTA não é inativada pelo líquido de Dakin na proporção $1: 1$.

GAVINI ${ }^{63}$, em 1992, avaliou in vitro, por meio da microscopia eletrônica de varredura, a limpeza da parede do canal radicular referente ao terço apical, após o preparo químico-mecânico, tendo como fonte de variação a solução irrigadora utilizada e o volume empregado. As soluções estudadas foram: soro fisiológico, EDTA a $17 \%$, ácido cítrico a $25 \%$ e hipoclorito de sódio a $1 \%$. Os resultados mostraram que a associação de $6 \mathrm{ml}$ de EDTA a 17\% e $6 \mathrm{ml}$ de hipoclorito de sódio a $1 \%$ proporcionou uma superfície dentinária livre de smear layer, e que o aumento do volume das soluções irrigadoras, auxilia significativamente na obtenção de um maior número de canalículos dentinários visíveis.

PÉCORA ${ }^{123}$, em 1992, avaliou o efeito das soluções de Dakin e de EDTA, isoladas, alternadas ou misturadas na proporção $1: 1$, sobre a permeabilidade da dentina radicular, verificando que tanto o uso alternado, como o uso associado destas soluções, resultaram em um aumento da permeabilidade dentinária.

PROKOPOWITSCH ${ }^{134}$, em 1994, estudou a permeabilidade e a limpeza das paredes dos canais radiculares de dentes com rizogênese incompleta, instrumentados e medicados com pasta de hidróxido de cálcio PA, veiculado em solução anestésica. Os resultados demonstraram que o EDTA-T e o creme EndoPTC associado ao hipoclorito de sódio a $1 \%$, proporcionaram um aumento na permeabilidade dentinária e uma melhor limpeza das paredes dos canais, constatada por meio de microscopia eletrônica de varredura.

GALVAN et al. ${ }^{59}$, em 1994, relataram que a redução na espessura da dentina, após o preparo dos canais radiculares, assim como, a presença da smear layer, alteram a permeabilidade dentinária. 
HAWKINSON et al. ${ }^{79}$, em 1994, demonstraram que a smear layer é capaz de retardar a penetração de microrganismos ( $E$. faecalis e $P$. gengivalis) na dentina radicular, nos períodos de 7 a 14 dias. Entretanto, no período de 21 dias, as bactérias foram capazes de penetrar até a junção cemento-dentinária. Com base nesses resultados, os autores concluíram que a smear layer não é uma barreira absoluta à infiltração bacteriana.

Por meio de microscopia eletrônica de varredura, GAVINI ${ }^{64}$, em 1994, avaliou a capacidade de dois sistemas de irrigação, um pressurizado e outro ultra-sônico, na remoção de smear layer. Esses sistemas foram empregados de maneira associada a diferentes agentes irrigantes (EDTA a 17\%, ácido cítrico a 25\%, hipoclorito de sódio a 1 e $2 \%$, e Tergentol-Furacin). Os resultados evidenciaram não haver diferença significante entre os métodos de irrigação estudados e, dentre as soluções analisadas, as mais efetivas na remoção de smear layer foram o EDTA a $17 \%$ e o ácido cítrico a $25 \%$.

GARBEROGLIO; BECCE ${ }^{61}$, em 1994, avaliaram in vitro, o efeito de seis soluções irrigantes sobre a smear layer produzida durante a instrumentação manual dos canais radiculares. Os resultados foram analisados com o auxílio de microscopia eletrônica de varredura. As soluções irrigantes avaliadas foram: hipoclorito de sódio a $1 \%$ e $5 \%$, uma combinação de ácido fosfórico a $24 \%$ e ácido cítrico a $10 \%$, soluções de EDTA a 0,2\%, 3\% e 17\%. As soluções de hipoclorito de sódio não foram capazes de remover a smear layer. A solução de EDTA a 0,2\% não removeu completamente a smear layer, especialmente dos orifícios dos túbulos dentinários. As outras três soluções irrigantes foram efetivas na remoção da smear layer, sem diferença estatisticamente significante entre si.

CRUZ FILHO ${ }^{37}$, em 1994, estudou a ação do EDTAC sobre a microdureza da dentina radicular nos terços cervical, médio e apical em diferentes tempos de aplicação (zero, 01, 02, 03, 05, 07, 10 minutos), e verificou que a microdureza dentinária varia de modo inversamente proporcional ao tempo de aplicação da solução de EDTAC. A redução da microdureza da dentina promovida pelo EDTAC ocorreu a partir de 1 minuto de aplicação, nos três terços (cervical, médio e apical), sendo que o terço cervical apresentou maior microdureza que os terços médio e apical, e estes não apresentaram diferença estatística significante entre si, em todos 
os tempos estudados. O autor constatou, também, que a dentina periférica, ou seja, a que está localizada próxima ao cemento, é mais dura que a dentina central e esta, por sua vez, é mais dura que a dentina próxima à câmara pulpar.

FAIRBANKS ${ }^{49}$, em 1995, estudou a ação das soluções de EDTA, EDTAC e EDTA-T sobre a microdureza da dentina radicular, com um tempo de aplicação de 5 minutos. As soluções foram aplicadas e a microdureza foi medida (dureza Vickers) evidenciando que todas as três soluções testadas foram capazes de promover a redução da microdureza dentinária. Entretanto, a solução de EDTAC foi significativamente mais efetiva que as soluções de EDTA e EDTA-T que, por sua vez, foram estatisticamente semelhantes.

$\mathrm{COELHO}^{34}$, em 1995, analisou in vitro, entre outras propriedades, a ação quelante do ácido cítrico a $50 \%$ e seu efeito sobre a permeabilidade dentinária, comparativamente ao EDTA a 17\%. A ação quelante das soluções foi avaliada por meio de espectrofotometria, enquanto que, a capacidade das soluções de modificar a permeabilidade dentinária foi quantificada pela mensuração da área de penetração do azul de metileno na dentina dos espécimes, usando, para tanto, cópias em papel fotográfico. Os resultados evidenciaram que o EDTA a $17 \%$ apresentou uma capacidade quelante significativamente maior que o ácido cítrico, embora este também tenha apresentado valores consideráveis. Quanto ao aumento da permeabilidade dentinária, o ácido cítrico mostrou-se significativamente melhor que o EDTA.

HAMAOKA; MOURA ${ }^{75}$, em 1996, avaliaram in vitro a permeabilidade da dentina radicular, por meio das variações da porcentagem de penetração dentinária dos corantes azul de metileno, Rodamina B ou tinta Nanquim. Foram observados os terços cervical, médio e apical, valendo-se do auxílio do sistema de análise de imagens DIRACOM-3. Os resultados obtidos demonstraram que a Rodamina B foi a que mais penetrou nos três terços radiculares estudados. Já a tinta Nanquim, demonstrou ser o pior corante dentre os empregados, neste estudo. A penetração dos corantes foi maior na região cervical e menor na apical.

BARKHORDAR et al. ${ }^{12}$, em 1997, avaliaram in vitro a capacidade de limpeza da doxiciclina em diferentes concentrações $(25 \mathrm{mg} / \mathrm{ml}, 50 \mathrm{mg} / \mathrm{ml}$, ou $100 \mathrm{mg} / \mathrm{ml})$. O exame por meio de microscopia eletrônica de varredura revelou que a doxiciclina na 
concentração de $100 \mathrm{mg} / \mathrm{ml}$ foi mais eficaz na remoção da smear layer que a solução de EDTA a $15 \%$. Com base nos resultados obtidos, os autores consideraram a doxiciclina uma possível alternativa para irrigação de canais radiculares.

CRUZ FILHO ${ }^{38}$, em 1998, estudou a ação das soluções de EDTAC 15\%, CDTA $1 \%$ e EGTA $1 \%$ sobre a microdureza da dentina radicular, no terço cervical de dentes humanos. A microdureza foi mensurada em aparelho de medir dureza Vickers com 50 gramas de carga e 15 segundos de aplicação, revelando que as soluções quelantes testadas reduziram a microdureza da dentina de modo estatisticamente semelhante.

ARAUJO ${ }^{5}$, em 1999, estudou, comparativamente, a permeabilidade da dentina radicular diante da presença ou ausência de cemento. Delimitou-se, em cada região proximal da raiz, uma área medindo $5 \mathrm{~mm}$ de altura por $1,5 \mathrm{~mm}$ de largura. Em uma das áreas previamente determinadas, o cemento foi removido para expor a dentina, enquanto que, na outra, o cemento foi preservado. Com excessão destas áreas, a superfície externa da raiz foi impermeabilizada e os espécimes foram imersos em azul de metileno a $1 \%$ durante 48 horas. Posteriormente, os dentes foram desgastados no sentido mesio-distal e observados em um microscópio com ampliação de 40x. Imagens digitais foram obtidas e, então, mensuradas com o auxílio do programa ImageLab. $O$ autor observou que o cemento atua como uma barreira protetora para a dentina. Na sua ausência, o corante atravessou toda dentina até atingir $\mathrm{o}$ canal.

ÇALT; SERPER ${ }^{24}$, em 2000, compararam a capacidade das soluções de EGTA e EDTA à $17 \%$ de remover a smear layer. Após o preparo até a lima de número 60 e irrigação dos canais radiculares com 10ml de EGTA a 17\% ou EDTA a $17 \%$ por 2 minutos, seguidos de irrigação final com $10 \mathrm{ml}$ de hipoclorito de sódio $5 \%$, os espécimes foram seccionados longitudinalmente e preparados para microscopia eletrônica de varredura. Os resultados evidenciaram que a smear layer foi completamente removida pela solução de EDTA, porém, esta provocou a erosão dos túbulos dentinários. Já a solução de EGTA promoveu a remoção de smear layer intracanal sem, entretanto, causar a erosão dos túbulos dentinários. Baseados nos 
resultados obtidos os autores sugeriram que o EGTA é um quelante alternativo ao EDTA para remoção da smear layer.

O'CONNELL et al. ${ }^{114}$, em 2000 , estudaram os efeitos de diferentes sais de EDTA na remoção da smear layer de canais radiculares. Foram utilizados: sal dissódico de EDTA a 15\% (pH 7,1; ajustado com $\mathrm{NaOH})$; sal tetrassódico de EDTA a $15 \%(\mathrm{pH} \mathrm{7,1;} \mathrm{ajustado} \mathrm{com} \mathrm{HCl}$ ) e sal tetrassódico de EDTA a 25\% $(\mathrm{pH} \mathrm{7,1;} \mathrm{ajustado}$ com $\mathrm{HCl}$ ). O exame por microscopia eletrônica de varredura, da superfície dos canais tratados com as soluções de EDTA e hipoclorito de sódio a 5,25\%, evidenciou a total remoção da smear layer nos terços cervical e médio. No terço apical, as soluções testadas foram menos eficazes. Nenhuma das soluções de EDTA, utilizadas isoladamente, foi eficaz na total remoção da smear layer. O sal tetrassódico de EDTA mostrou ser mais barato e tão eficaz na remoção da smear layer, quanto o sal dissódico de EDTA, comumente utilizado.

SCELZA; ANTONIAZZI; SCELZA ${ }^{146}$, em 2000, avaliaram a eficácia de três soluções irrigantes (ácido cítrico a $10 \%$, EDTA-T ou $\mathrm{H}_{2} \mathrm{O}_{2}$ a $3 \%$ ), na remoção da smear layer, após o preparo dos canais radiculares. Fotomicrografias, realizadas por meio de microscopia eletrônica de varredura, foram examinadas por meio da contagem do número de túbulos dentinários visíveis, por três observadores. O maior número de túbulos visíveis, nos três grupos experimentais, foi observado no terço cervical, seguido do médio, e do apical. Não houve diferença estatisticamente significante entre os dentes irrigados com ácido cítrico ou EDTA-T. Porém, foram observados significativamente mais túbulos dentinários nestes dois grupos, quando comparados aos dentes irrigados com peróxido de hidrogênio $\left(\mathrm{H}_{2} \mathrm{O}_{2}\right)$.

DI LENARDA; CADENARO; SBAIZERO ${ }^{44}$, em 2000, estudaram a capacidade de limpeza e remoção da smear layer das seguintes soluções: hipoclorito de sódio a $5 \%$ isoladamente, ácido cítrico $\left(1 \mathrm{~mol}^{-1}\right)$ alternado com o hipoclorito de sódio ou EDTA a $15 \%$ acrescido de Cetrimide (tensoativo catiônico). Após o preparo dos canais e irrigação com as respectivas soluções, os dentes foram fraturados longitudinalmente e examinados por meio de microscopia eletrônica de varredura, com aumentos de 300x e 1000x. Análises qualitativa e quantitativa foram realizadas por meio do exame das imagens obtidas, em um programa de computador. A análise qualitativa das imagens em 300x e 1000x de aumento, não mostrou diferença 
estatisticamente significante quanto à capacidade de limpeza do ácido cítrico, do EDTA ou do hipoclorito de sódio. A avaliação quantitativa do número de túbulos abertos por unidade de área da superfície, demonstrou que o ácido cítrico foi estatisticamente semelhante ao EDTA, porém, estas soluções foram superiores ao hipoclorito de sódio, quanto à capacidade de limpeza e remoção da smear layer.

TASMAN et al. ${ }^{169}$, em 2000, avaliaram a tensão superficial de algumas soluções: água destilada, solução de Ringer, soro fisiológico, $\mathrm{NaOCl}$ a 2,5\%, $\mathrm{NaOCl}$ a $5 \%$, EDTA a $17 \%, \mathrm{H}_{2} \mathrm{O}_{2}$ a $3 \%$, Citanest a $3 \%$, Ultracaina DS, e Cetrexidin (clorexidina a $0,2 \%+$ tensoativo). A tensão superficial foi mensurada por meio do método de Ring com o auxílio de um tensiômetro. A água destilada, o soro fisiológico e a solução de Ringer apresentaram os maiores valores de tensão superficial, enquanto que o hipoclorito de sódio ( $\mathrm{NaOCl}$ a $2,5 \%$ e a 5\%) e o EDTA, apresentaram valores relativamente baixos. Duas soluções anestésicas (Citanest e Ultracaina) apresentaram valores semelhantes aos das soluções de hipoclorito de sódio e EDTA. A solução Cetrexidin apresentou os menores valores de tensão superficial dentre as soluções testadas. Os autores ressaltaram que uma solução com baixa tensão superficial seria capaz de penetrar melhor nos túbulos dentinários.

PETERS; BARBAKOW ${ }^{131}$, em 2000, avaliaram, por meio de microscopia eletrônica de varredura, a presença de debris e smear layer em canais instrumentados com os sistemas Lightspeed e ProFile, utilizando-se como soluções irrigantes a água ou o hipoclorito de sódio a $5,25 \%$ alternado com EDTA a $17 \%$. Os resultados demonstraram que, no grupo irrigado com água, a presença de debris e smear layer foi semelhante em todos os terços radiculares, independente do instrumento utilizado (Lightspeed ou ProFile). Nenhum dos dois sistemas testados foi superior ao outro, na remoção de debris. Porém, o sistema Lightspeed, por propiciar um preparo mais amplo, promoveu uma melhor remoção da smear layer no grupo tratado com hipoclorito de sódio e EDTA.

SCHMALZ et al. ${ }^{150}$, em 2001, estudaram, comparativamente, a permeabilidade da dentina bovina e da dentina humana, por meio do método de condução hidráulica e do fluxo de difusão de água. Discos de dentina bovina e humana, de diferentes espessuras, foram obtidos e montados em um dispositivo especialmente desenvolvido para o experimento. Os resultados demonstraram que a 
permeabilidade das dentinas, humana e bovina, aumentou com o pré-tratamento com ácido cítrico a 50\%, por 30 segundos, e apresentou uma relação inversamente proporcional à espessura do disco de dentina. Os autores concluíram que a dentina bovina, próxima à junção cemento-esmalte, parece ser uma alternativa viável em substituição à dentina coronária humana para testes, in vitro, na avaliação da permeabilidade dentinária.

CRUZ-FILHO et al. ${ }^{40}$, em 2001, avaliaram, in vitro, o efeito do EDTAC, do CDTA e do EGTA, na microdureza da dentina radicular do terço cervical de dentes humanos. Os espécimes de dentina preparados foram submetidos à aplicação de $15 \mu \mathrm{l}$ de EDTAC a 15\%, CDTA a 1\%, EGTA a 1\% ou água destilada e deionizada (controle). Por meio de um dispositivo para mensuração da microdureza Vicker's (carga de $50 \mathrm{~g}$, por 15 segundos), os autores verificaram que as três soluções quelantes reduziram significativamente a microdureza da dentina em comparação com a água destilada. Entretanto, não houve diferença estatisticamente significante entre as três soluções quelantes testadas.

DOGAN; ÇALT ${ }^{47}$, em 2001, verificaram, in vitro, o efeito de agentes quelantes (EDTA e RC-Prep) e do hipoclorito de sódio ( $\mathrm{NaOCl}$ ), no conteúdo mineral da dentina radicular, por meio de microanálise de espectrofotometria de energia dispersiva. Os espécimes de dentina foram divididos em seis grupos. Os dois primeiros grupos foram tratados com EDTA ou RC-Prep, seguido de irrigação com $\mathrm{NaOCl}$. Os grupos restantes foram tratados, respectivamente, com EDTA, RC-Prep, $\mathrm{NaOCl}$ e solução salina (grupo controle). Os níveis de cálcio, fósforo e magnésio foram mensurados após o tratamento da dentina radicular. Os resultados demonstraram que o uso do EDTA, combinado com irrigação final com $\mathrm{NaOCl}$, ou o uso do $\mathrm{NaOCl}$, isoladamente, alteraram a proporção cálcio-fósforo da dentina, significativamente. Os autores, entretanto, não verificaram alteração significante nos níveis de magnésio após o uso dos agentes quelantes seguidos de irrigação com hipoclorito de sódio.

HATA et al. ${ }^{78}$, em 2001, avaliaram, por meio de microscopia eletrônica de varredura, a eficácia da água com potencial oxidativo (OPW) como solução irrigadora para remoção da smear layer e/ou debris, das paredes de canais radiculares instrumentados. Os resultados evidenciaram que o uso da água com 
potencial oxidativo, após a instrumentação com hipoclorito de sódio a $5 \%$ proporcionou efeitos similares aos observados com o uso do EDTA a 15\%, na remoção de debris e da smear layer.

HAZNEDAROGLU; ERSEV ${ }^{80}$, em 2001, avaliaram, por meio da microscopia eletrônica de varredura, a capacidade do hidrocloreto de tetraciclina de remover smear layer de canais radiculares instrumentados, comparativamente, à água destilada, ao hipoclorito de sódio a $2,5 \%$ e ao ácido cítrico a $50 \%$. Os resultados demonstraram que a água destilada e o hipoclorito foram ineficazes na remoção da smear layer, enquanto que, o ácido cítrico e o hidrocloreto de tetraciclina foram significativamente mais eficazes, sem diferença estatisticamente significante entre si. Os autores observaram, também, que o hidrocloreto de tetraciclina desmineralizou menos a dentina peritubular.

RIBEIRO $^{140}$, em 2001, avaliou, por meio de um método histoquímico, a permeabilidade dentinária dos canais radiculares instrumentados, com a utilização das seguintes soluções irrigadoras: água destilada, lauril dietilenoglicol éter sulfato de sódio a $0,1 \%$, hipoclorito de sódio a $1 \%$; EDTA a $15 \%$ e ácido cítrico a $10 \%$, associadas ou não ao uso do laser de Er:YAG. Os resultados mostraram que a solução de hipoclorito de sódio a $1 \%$, utilizada isoladamente, e o uso da água destilada + laser Er:YAG apresentaram maior evidenciação de permeabilidade, de modo estatisticamente semelhante entre si e significantemente diferentes dos demais tratamentos. A água destilada e a solução de lauril dietilenoglicol éter sulfato de sódio a $0,1 \%$, quando utilizadas isoladamente, apresentaram menor evidenciação da permeabilidade dentinária que as demais soluções, de modo estatisticamente semelhante entre si. A utilização do hipoclorito de sódio a 1\% + laser, EDTA + laser, ácido cítrico + laser, lauril dietilenoglicol éter sulfato de sódio a $0,1 \%+$ laser e as soluções de EDTA e ácido cítrico utilizadas isoladamente, apresentaram-se de modo estatisticamente semelhantes entre si e com valores intermediários em relação aos demais tratamentos realizados, no que diz respeito à evidenciação de permeabilidade dentinária.

$\mathrm{POLO}^{132}$, em 2002, avaliou in vitro, por meio da espectrofotometria e pela análise da permeabilidade dentinária, a ação do gel Carisolv, quando utilizado na irrigação final de canais radiculares. A permeabilidade dentinária foi quantificada por 
meio da penetração do corante Rodamina B a $1 \%$ na massa dentinária. Os resultados mostraram que a irrigação final com o gel Carisolv ou com a solução de EDTA-T, promoveu um aumento significativo da permeabilidade da dentina radicular, sendo que, no terço apical, o aumento foi de menor intensidade.

BRZOZOWSKI ${ }^{22}$, em 2002, analisou a influência da aplicação do tetrafluoreto de titânio a 4\%, na permeabilidade dentinária do sistema endodôntico, por meio da quantificação da penetração da Rodamina B a 1\%, na dentina. A partir dos resultados, a autora observou um aumento da penetração do corante nos espécimes que receberam preparo químico-mecânico prévio, sendo maior naqueles, cuja irrigação final foi feita com EDTA-T a 15\%. Em relação à ação do tetrafluoreto de titânio, os canais que receberam a sua aplicação tiveram a permeabilidade consideravelmente reduzida, independente da substância irrigadora utilizada durante o preparo químico-mecânico.

DEZOTTI; SOUZA JÚNIOR; NISHIYAMA ${ }^{43}$, em 2002, avaliaram a permeabilidade da dentina cervical em dentes tratados endodonticamente, submetidos ao clareamento interno com perborato de sódio e peróxido de hidrogênio a $30 \%$. Após a obturação, os dentes foram divididos em grupos de acordo com o nível de corte do material obturador e selamento, ou não, da embocadura dos canais com ionômero de vidro. O grupo controle foi composto por dentes que não receberam a pasta clareadora. Setenta e duas horas após o procedimento de clareamento, os dentes foram imersos em fuccina básica a 0,5\% por 24 horas para determinar possíveis diferenças na permeabilidade da dentina cervical. Os resultados demonstraram que a permeabilidade dentinária aumentou em todos os grupos experimentais, em comparação ao grupo controle. Os autores sugeriram que esta via de comunicação, entre a câmara pulpar e a superfície externa da raiz, poderia ser, possivelmente, responsável por desencadear reabsorções externas.

GUERISOLI et al. ${ }^{73}$, em 2002, avaliaram a capacidade de remoção da smear layer pela solução de EDTAC a 15\%, pelo hipoclorito de sódio a 1\%, e pela água destilada, todas com agitação ultra-sônica. Após o preparo e irrigação dos canais, os dentes foram partidos longitudinalmente e os terços radiculares (cervical, médio e apical), foram examinados por meio de microscopia eletrônica de varredura. Os resultados demonstraram que, sob agitação ultra-sônica, a solução de hipoclorito de 
sódio associada ao EDTAC foi capaz de remover a smear layer das paredes dos canais radiculares, enquanto que a irrigação com água destilada e com hipoclorito de sódio a $1 \%$, isoladamente, não foram efetivas.

VIEGAS et al. ${ }^{178}$, em 2002, avaliaram, por meio de microscopia eletrônica de varredura, a limpeza das paredes do terço apical de canais radiculares, com o uso do hipoclorito de sódio, isoladamente, ou associado ao EDTA a $17 \%$ ou ao Glyde File Prep $\AA$, durante o preparo químico-mecânico dos canais radiculares. A análise dos resultados evidenciou que o uso do hipoclorito de sódio associado ao EDTA a $17 \%$ promoveu paredes dentinárias mais limpas, quando comparadas às obtidas nos outros grupos experimentais.

ÇALT; SERPER ${ }^{25}$, em 2002, avaliaram os efeitos do EDTA a $17 \%$ sobre a smear layer e a estrutura dentinária de canais radiculares instrumentados. Após o preparo dos canais até uma lima de número 60 , os terços apicais e coronários de cada raíz foram removidos e descartados, sendo aproveitados apenas o terço médio, que foi partido longitudunalmente, dando origem à duas hemi-secções. Enquanto uma das hemisecções, da mesma raiz, recebeu a aplicação de $10 \mathrm{ml}$ de EDTA a $17 \%$ por 1 minuto, a outra recebeu a mesma quantidade de EDTA, porém, por 10 minutos. Em seguida, os espécimes foram irrigados com $10 \mathrm{ml}$ de hipoclorito de sódio a $5 \%$ e, posteriormente, foram examinados por microscopia eletrônica de varredura. Os resultados demonstraram que a aplicação do EDTA por 1 minuto foi eficaz na remoção da smear layer, enquanto que, a aplicação por 10 minutos causou uma excessiva erosão da dentina.

SOUSA-NETO et al. ${ }^{161}$, em 2002, avaliaram o efeito do EDTA a 15\%, EGTA a $1 \%$ e CDTA a $1 \%$, na adesividade e na infiltração marginal apical em diferentes cimentos obturadores de canais radiculares (Sealer 26, Sealapex, N-Rickert e Endofill). Os autores verificaram que a solução de EDTA apresentou os melhores resultados, promovendo uma maior adesividade dos cimentos à dentina e um melhor selamento apical.

CRUZ-FILHO et al. $^{39}$, em 2002, avaliaram o efeito de diferentes concentrações de EGTA (1\%, 3\% e 5\%) sobre a microdureza da dentina radicular, utilizando cortes transversais cervicais de raízes de incisivos centrais superiores. A microdureza Vickers foi medida com a aplicação de uma carga de $50 \mathrm{~g}$ por 15 
segundos sobre os fragmentos de dentina obtidos. Os resultados permitiram concluir que nas três concentrações estudadas, a solução de EGTA reduziu a microdureza da dentina, de forma estatísticamente diferente. A capacidade de redução da microdureza dentinária foi proporcional à concentração da solução, isto é, quanto maior a concentração da solução de EGTA, maior a sua capacidade em reduzir a microdureza da dentina.

SERPER; ÇALT ${ }^{154}$, em 2002, compararam a capacidade de desmineralização da dentina, da solução de EDTA a $10 \%$ ou 17\%, e pH 7,5 ou 9,0. A desmineralização foi mensurada por meio da quantidade de fósforo liberado do tecido dentinário, após $1,3,5,10$ ou 15 minutos de aplicação. Os autores verificaram que a quantidade de fósforo liberado da dentina foi maior com o aumento da concentração da solução de EDTA e com o aumento do tempo de aplicação, e o efeito desmineralizador da solução de EDTA foi melhor no pH 7,5.

SOUZA et al. ${ }^{162}$, em 2003, avaliaram a ação dos quelantes EDTA, EGTA e CDTA na remoção de smear layer das paredes dentinárias do terço apical dos canais radiculares. Após a instrumentação e secção longitudinal dos dentes, os canais foram irrigados com $3 \mathrm{ml}$ de EDTA a 17\%, CDTA a 1\%, EGTA a $1 \%$ e hipoclorito de sódio a 5,25\% por 3 minutos. A eficácia na remoção de smear layer foi analisada por meio de microscopia eletrônica de varredura e os resultados mostraram-se, estatisticamente, melhores no grupo do EDTA a $17 \%$ seguido do EGTA a $1 \%$, CDTA a $1 \%$, sendo que o hipoclorito de sódio a $5,25 \%$ não foi eficiente na remoção da smear layer.

VISWANATH; HEGDE; MUNSHI ${ }^{179}$, em 2003, compararam o efeito do EGTA e do EDTA na capacidade de remoção de smear layer das paredes dos canais. Após a instrumentação dos canais e irrigação com as diferentes soluções estudadas, os espécimes foram processados para exame em microscópio eletrônico de varredura. Os resultados evidenciaram que tanto a solução de EDTA, quanto a de EGTA, foram capazes de remover completamente a smear layer. Entretanto, a solução de EDTA provocou erosão e conjugação dos túbulos dentinários, enquanto que, a solução de EGTA não induziu qualquer erosão da superfície da parede dentinária do canal radicular. Os autores concluíram que a solução de EGTA pode ser usada como um quelante alternativo efetivo para remoção da smear layer. 
TORABINEJAD et al. ${ }^{177}$, em 2003, investigaram os efeitos do MTAD, uma mistura de antibiótico (doxiciclina), ácido cítrico e um tensoativo (Tween 80), como solução irrigante de canais radiculares, e compararam seus resultados com os da água destilada, do hipoclorito de sódio a 5,25\% e do EDTA a 17\%. A presença ou ausência de smear layer, e a erosão da superfície dentinária dos terços cervical, médio e apical, foram observadas por meio de microscopia eletrônica de varredura. Os resultados demonstraram que a solução MTAD foi efetiva na remoção da smear layer sem alterar, significativamente, a estrutura dos túbulos dentinários.

SCELZA; TEIXEIRA; SCELZA ${ }^{148}$, em 2003, avaliaram a eficácia do EDTA a $17 \%$, acrescido de $1,25 \%$ de lauril éter sulfato de sódio (EDTA-T), ácido cítrico a $10 \%$ e EDTA a 17\%, utilizados por 3, 10 ou 15 minutos de aplicação, na descalcificação da dentina radicular. A concentração de íons cálcio extraídos foi determinada por espectroscopia de absorção atômica. Os resultados demonstraram não haver diferença significante entre o ácido cítrico e o EDTA na extração de íons cálcio quando essas soluções foram aplicadas por 3 minutos. Já a solução de EDTA$\mathrm{T}$, apresentou uma menor eficácia na extração de íons cálcio da dentina, quando comparada às outras soluções testadas. Também não houve diferença significante entre o ácido cítrico e o EDTA, quando a aplicação foi realizada por 10 ou 15 minutos, assim como não houve diferença entre o EDTA e o EDTA-T. Entretanto, o ácido cítrico foi superior ao EDTA-T em termos de extração de íons cálcio da dentina radicular, quando a aplicação se deu por 10 ou 15 minutos.

SABINS; JOHNSON; HELLSTEIN ${ }^{143}$, em 2003, avaliaram, comparativamente, a capacidade de limpeza da irrigação sônica ou ultra-sônica passiva, de curta duração, após a instrumentação de canais radiculares. Os canais preparados foram divididos em 5 grupos para receberem diferentes tratamentos: grupo 1, irrigação final com hipoclorito de sódio a 5,25\% (controle); grupos 2 e 3 receberam irrigação sônica passiva por 30 e 60 segundos, respectivamente; grupo 4 e 5 receberam irrigação ultra-sônica passiva por 30 e 60 segundos, respectivamente. Os dentes foram, então, partidos longitudinalmente, fotografados com uma câmera digital e examinados no programa Adobe Photoshop 5.0, com um aumento de 100x, para cálculo da porcentagem de área da superfície do canal, recoberta por debris. Os resultados demonstraram que a irrigação sônica e a ultra-sônica, por 30 segundos, 
promoveram uma melhor remoção de debris, quando comparadas à irrigação convencional. Dentre estas, a irrigação ultra-sônica apresentou, significativamente, os melhores resultados.

BELTZ; TORABINEJAD; POURESMAIL ${ }^{16}$, em 2003, analisaram, quantitativamente, a ação solubilizante do MTAD, hipoclorito de sódio e do EDTA sobre o tecido pulpar necrótico e a dentina bovina, ambos na forma pulverizada, representando, assim, os componentes orgânicos e inorgânicos da smear layer. Amostras liofilizadas dos tecidos foram misturadas por 2 horas a $37^{\circ} \mathrm{C}$ com MTAD, três concentrações de hipoclorito de sódio (1,3\%, 2,6\% e 5,25\%), EDTA a $17 \%$ ou solução salina isotônica. Os tecidos não dissolvidos foram lavados e liofilizados. A alteração no peso dos tecidos, após a exposição aos agentes irrigantes foi mensurada para quantificar a solubilização. Os resultados evidenciaram que as soluções de hipoclorito foram efetivas na solubilização dos componentes orgânicos, tanto da polpa, quanto da dentina. A solução de hipoclorito de sódio a $5,25 \%$ foi capaz de dissolver, praticamente, todo o componente orgânico da dentina. Em relação à dissolução do tecido pulpar, as soluções de hipoclorito de sódio a 2,6\% e a $5,25 \%$ obtiveram resultados estatisticamente semelhantes. A solução de EDTA foi capaz de dissolver mais de $70 \%$ da dentina e mais de $51 \%$ do tecido pulpar, sendo semelhante à capacidade observada com o MTAD.

JEON et al. ${ }^{83}$, em 2003, avaliaram a qualidade e a quantidade de smear layer gerada no preparo do terço apical de canais retos, com dois instrumentos rotatórios de níquel-titânio (ProFile ${ }^{\circledR}$ e Hero $642^{\circledR}$ ) e um de aço inoxidável (Mani ${ }^{\circledR}$ ), com diferentes desenhos de lâminas cortantes. Todos os canais foram instrumentados até o diâmetro de número 40 , utilizando-se $3 \mathrm{ml}$ de hipoclorito de sódio a $1 \%$, a cada instrumento empregado. Após o preparo, as raízes foram fraturadas longitudinalmente e examinadas em microscópio eletrônico de varredura. Escores foram utilizados para estabelecer o grau de acúmulo de smear layer. Todos os instrumentos testados deixaram smear layer como resultado da instrumentação, porém, nos canais instrumentados com o sistema Hero 642, observou-se uma menor quantidade de smear layer remanescente. Os autores concluíram que o desenho da lâmina cortante pode afetar a limpeza das paredes do terço apical de canais radiculares. 
BRUGNERA JÚNIOR et al. ${ }^{21}$, em 2003, avaliaram, por um método histoquímico, o efeito da aplicação dos lasers Er:YAG e Nd:YAG sobre a permeabilidade da dentina radicular utilizando água destilada e deionizada, ou hipoclorito de sódio a $1 \%$ como soluções irrigadoras. Os autores verificaram que o uso combinado do laser Er:YAG com água destilada promoveu um maior aumento na permeabilidade da dentina radicular, enquanto que a aplicação do laser Nd:YAG com água destilada ou hipoclorito de sódio $1 \%$ resultou num menor aumento da permeabilidade dentinária que a observada nos outros grupos.

CARDOSO $^{27}$, em 2003, avaliou in vitro a permeabilidade dentinária dos terços cervical, médio e apical dos canais radiculares, após a instrumentação rotatória, variando-se a substância química auxiliar (Endo-PTC, EDTA-T a 17\% ou Clorexidina a $2 \%$ ). A permeabilidade dentinária foi quantificada por meio da penetração do corante Rodamina B a 1\% na dentina. Os resultados demonstraram, de modo geral, que, dentre as soluções irrigadoras estudadas, o creme Endo-PTC, neutralizado pelo líquido de Dakin após o preparo químico-mecânico, proporcionou o maior aumento no índice de permeabilidade dentinária.

RALDI; LAGE MARQUES ${ }^{138}$, em 2003, avaliaram in vitro os efeitos da interação entre soluções irrigadoras desmineralizadoras (EDTA-T e ácido cítrico), medicação intracanal (NDP) e laser (Er:YAG) na permeabilidade dentinária. Os canais radiculares foram preenchidos com Rodamina B solubilizados na medicação intracanal NDP. Após o período experimental os espécimes foram cortados transversalmente para posterior leitura com o programa ImageLab. Os melhores resultados foram obtidos quando da interação entre a solução irrigante desmineralizadora (EDTA-T ou ácido cítrico) e a associação medicação intracanal / laser Er:YAG. Nestes grupos, constatou-se que a diferença de penetração da Rodamina B no terço apical foi, em média, 29\% maior que nos demais grupos experimentais.

SETLOCK et al. ${ }^{155}$, em 2003, avaliaram a capacidade de limpeza e remoção da smear layer após a instrumentação rotatória crown-down, utilizando $12 \mathrm{ml}$ de $\mathrm{NaOCl} 5,25 \%$, seguidos de $6 \mathrm{ml}$ de EDTA a 17\%, e, finalmente, $4 \mathrm{ml}$ de $\mathrm{NaOCl}$ a $5,25 \%$. Variou-se, apenas, o método de irrigação: sistema de irrigação do aparelho Quantec-E (bomba peristáltica) ou por meio de seringa convencional. Os resultados 
evidenciaram que o sistema de irrigação do aparelho Quantec-E promoveu uma melhor limpeza das paredes dos canais radiculares, com menor quantidade de debris, e melhor remoção da smear layer no terço coronário, quando comparado com a irrigação por meio de seringa. Entretanto, não foram observadas diferenças entre os métodos de irrigação, nos terços médio e apical.

SKELTON MACEDO ${ }^{159}$, em 2003, avaliou, comparativamente, três métodos de leitura aplicados à infiltração de corante em dentina humana. Foram utilizadas raízes de dentes unirradiculados, infiltradas com azul de metileno a 0,5 ou $2 \%$, pelo período de 24 ou 48 horas. Os métodos de leitura incluíram uma adaptação do método de MARSHALL; MASSLER; DUTE $^{98}$, de 1960, com a variação da analise dos dados a partir de uma imagem impressa, além de outros dois sistemas de avaliação digitais, nos quais, programas de análise de imagens puderam ser aplicados, utilizando maneiras distintas de leitura: contornar a área a ser mensurada com auxílio de cursor dirigido pelo mouse, ou analisar um determinado intervalo de cor que envolvia as tonalidades indicativas da infiltração do corante. Os resultados demonstraram que o método de leitura da imagem impressa apresentou resultados estatisticamente significantes quando comparado com os demais métodos digitais, tendendo a oferecer maiores valores. Os métodos de leitura digitais foram estatisticamente semelhantes entre si, levando o autor a sugerir que estes podem ser utiizados com segurança, nas análises de área de infiltração de corante em dentina. Neste experimento, não houve diferença significante em relação à concentração da solução corante utilizada $(0,5$ ou $2 \%)$ ou em relação aos períodos experimentais de aplicação (24 ou 48 hs).

NÓRA et al. ${ }^{113}$, em 2003, avaliaram a permeabilidade dentinária em dentes submetidos à reintervenção endodôntica, obturados com três diferentes cimentos endodônticos: N-Rickert, AH Plus ou Sealapex. Os canais foram desobturados e, em seguida, reinstrumentados, utilizando como soluções irrigadoras, o Endo-PTC e líquido de Dakin. Após a instrumentação, os canais foram irrigados com EDTA-T a $15 \%$ por 5 minutos, neutralizados com $10 \mathrm{ml}$ de líquido de Dakin. Os espécimes foram, então, imersos em Rodamina B a 0,5\%, por 48 horas, sulcados e clivados longitudinalmente. A penetração do corante foi analisada por meio de microscopia estereoscópica, e mensurada com o auxílio do programa Imagem Pro-plus. A partir 
dos resultados os autores puderam concluír que a permeabilidade dentinária foi restabelecida após a reintervenção, porém, sem diferença estatisticamente significante entre os três grupos experimentais.

CHAMMAS; LAGE-MARQUES ${ }^{30}$, em 2004, avaliaram in vitro a variação da permeabilidade da dentina após a renovação da substância química auxiliar após o uso de cada instrumento (Grupo I), com renovação a cada dois instrumentos (Grupo II) e somente no final do preparo químico-mecânico. Após o preparo dos canais, foi utilizado, como corante indicador, a Rodamina B a 1\%. Os espécimes foram submetidos a cortes transversais com $1,5 \mathrm{~mm}$ de espessura. A penetração do corante foi determinada pela mensuração da área de dentina corada por meio do programa Imagelab. Os resultados obtidos permitiram concluir que a freqüência de renovação da substância química auxiliar não tem influência sobre a permeabilidade da dentina do canal radicular.

CARRASCO; PÉCORA; FRÖNER ${ }^{29}$, em 2004, avaliaram, quantitativamente, por meio de um método histo-químico, a permeabilidade dentinária da câmara pulpar, após o uso de diferentes soluções irrigantes (água destilada, EDTA a 17\% e hipoclorito de sódio a 1\%), com ou sem a ativação com ultra-som, previamente à aplicação do perborato de sódio, para o clareamento dentário interno. Os autores verificaram que a aplicação do ultra-som resultou em um aumento da permeabilidade dentinária, independente da solução irrigadora utilizada. Dentre as soluções estudadas, a de EDTA a $17 \%$ promoveu um maior aumento na permeabilidade dentinária, em comparação à solução de hipoclorito de sódio a $1 \%$ e à água destilada. Os autores sugeriram que o aumento da permeabilidade, promovido pela aplicação do ultra-som, poderia permitir o uso de agentes clareadores menos agressivos aos tecidos dentais.

ARI; ERDEMIR; BELLI ${ }^{6}$, em 2004, avaliaram o efeito de diversas soluções irrigantes na microdureza e rugosidade da dentina radicular. As soluções estudadas foram: $\mathrm{NaOCl}$ a $5,25 \%, \mathrm{NaOCl} 2,5 \%, \mathrm{H}_{2} \mathrm{O}_{2}$ a $3 \%$, EDTA a $17 \%$, gluconato de clorexidina a $0,2 \%$ e água destilada (controle). O tempo de aplicação das soluções sobre a dentina foi de 15 minutos. Os resultados evidenciaram que todas as soluções irrigantes estudadas reduziram a microdureza Vickers da dentina, com 
exceção da clorexidina. Tanto a água oxigenada a 3\% $\left(\mathrm{H}_{2} \mathrm{O}_{2}\right)$, quanto a clorexidina, não afetaram a rugosidade da dentina radicular.

SERAFINO et al. ${ }^{153}$, em 2004 , avaliaram a limpeza da superfície das paredes de canais radiculares após o preparo para retentores intrarradiculares. Os canais foram preparados com instrumentos rotatórios Quantec de níquel-titânio e irrigados com hipoclorito de sódio a 5,25\% a cada troca de instrumento ou com hipoclorito de sódio e EDTA a 10\%, alternadamente. Uma vez preparados, os canais foram obturados por meio da técnica convencional de condensação lateral da guta-percha ou por meio da técnica de condensação vertical da guta-percha aquecida. Após o preparo para retentores intrarradiculares, as paredes dos canais foram condicionadas com ácido fosfórico em gel por 15 segundos e lavadas com $5 \mathrm{ml}$ de água. Estas raízes foram, então, fraturadas, longitudinalmente, e examinadas por meio de microscopia eletrônica de varredura. A quantidade de debris, smear layer, restos de material obturador e túbulos dentinários desobstruídos foram ranqueados. Maiores quantidades de debris, smear layer, restos de material obturador e túbulos dentinários obstruídos, foram observadas nas porções mais apicais dos preparos para retentores. Nas porções média e cervical dos preparos, foram observadas, alternadamente, áreas de dentina limpa e áreas de dentina recoberta com smear layer. Os autores concluíram que, independente da técnica utilizada, a superfície resultante encontrava-se inadequada para procedimentos adesivos e cimentação de retentores com cimentos resinosos.

SCELZA et al. ${ }^{147}$, em 2004, conduziram um estudo para avaliar o efeito do EDTA-T, do EDTA a $17 \%$ e do ácido cítrico a $10 \%$ na remoção da smear layer das paredes de canais radiculares, após a irrigação final por 3, 10 ou 15 minutos de aplicação. Após a irrigação, os dentes foram partidos longitudinalmente, para exame por microscopia eletrônica de varredura. O número de túbulos dentinários abertos por unidade de área $\left(\mathrm{mm}^{2}\right)$, foi quantificado com o auxílio de um programa de computador. Os resultados demonstraram que as soluções testadas foram efetivas no período de aplicação mais curto (3 minutos) e não mostraram melhora no efeito com o aumento no tempo de aplicação.

PEREZ; ROUQUEYROL-POURCEL ${ }^{129}$, em 2005, estudaram, in vitro, a capacidade da solução de EDTA a $8 \%$ de remover debris e smear layer produzidos 
durante o preparo de canais radiculares. Canais de dentes unirradiculados foram instrumentados e, então, irrigados com a solução de hipoclorito de sódio a 3,5\%. Em seguida, os mesmos foram divididos em 6 grupos para receberem diferentes tratamentos: irrigação com EDTA a $8 \%$ ou a $15 \%$ por 1 ou 3 minutos, com ou sem irrigação final com solução salina. Após o preparo os dentes foram seccionados e preparados para observação em microscópio eletrônico de varredura. Os resultados demonstraram que a irrigação final com EDTA a $8 \%$ por 3 minutos é tão eficiente na remoção de debris e smear layer, quanto a irrigação com EDTA a 15\%, por 1 minuto.

PUAPICHARTDUMRONG; IKEDA; SUDA ${ }^{136}$, em 2005, avaliaram a influência da presença de remanescentes de tecido pulpar sobre a permeabilidade da dentina humana por meio de um dispositivo experimental de monitoração de difusão de substâncias. A concentração de naproxeno de sódio (substância utilizada) que penetrou através do disco de dentina preparado, antes e após a remoção dos remanescentes do tecido pulpar, foi determinada por meio de espectrofotometria. Os resultados evidenciaram que a presença de restos de tecido pulpar influencia significativamente a permeabilidade, ou seja, a difusão de substâncias através da dentina.

TEIXEIRA; FELIPPE; FELIPPE ${ }^{171}$, em 2005, estudaram os efeitos do tempo de aplicação do EDTA a 15\% e do hipoclorito de sódio a 1\%, na remoção da smear layer, por meio de microscopia eletrônica de varredura. Os canais foram irrigados com $3 \mathrm{ml}$ de EDTA seguidos de $3 \mathrm{ml}$ de hipoclorito de sódio, variando-se o tempo de permanência das soluções no interior dos canais: 1, 3 ou 5 minutos. As paredes dentinárias dos terços cervical, médio e apical foram examinadas. Os autores verificaram que a associação do EDTA com o hipoclorito de sódio foi capaz de remover a smear layer dos terços cervical e médio dos canais radiculares em todos os tempos de aplicação (1, 3, ou 5 minutos). No terço apical, a eficácia da remoção da smear layer foi reduzida, particularmente, no grupo tratado por 1 minuto.

CRUMPTON; GOODELL; MCCLANAHAN ${ }^{36}$, em 2005, quantificaram o volume de EDTA a 17\% necessário para remover, de modo eficaz, a smear layer de canais instrumentados com sistema rotatório Profile GT. Os canais instrumentados foram irrigados com 1, 3, ou $10 \mathrm{ml}$ de EDTA a $17 \%$ por 1 minuto, seguidos de $3 \mathrm{ml}$ de $\mathrm{NaOCl} 5,25 \%$. Escores foram utilizados para avaliar a presença de debris nas 
amostras. A presença da smear layer foi observada por meio de microscopia eletrônica de varredura. Os resultados demonstraram não haver diferença estatisticamente significante entre os grupos, em relação a presença de debris remanescentes e qualidade da remoção da smear layer. A irrigação dos canais com volumes superiores a $1 \mathrm{ml}$ de EDTA, não resultou em melhora na remoção de debris. A irrigação final com $1 \mathrm{ml}$ de EDTA a 17\%, seguido de $3 \mathrm{ml}$ de $\mathrm{NaOCl}$ 5,25\% foi eficaz na remoção da smear layer dos canais instrumentados.

ZEHNDER et al. ${ }^{190}$, em 2005, avaliaram o efeito da redução da tensão superficial de agentes quelantes na capacidade de remoção de cálcio das paredes de canais radiculares instrumentados. As soluções de EDTA a 15,5\%, ácido cítrico a $10 \%$ e 1-hidroxietilideno-1, 1-bifosfonato a 18\% (HEBP) foram preparadas com e sem a adição de $1 \%$ de polisorbato (Tween 80 ) e $9 \%$ de propilenoglicol. A tensão superficial dessas soluções foi mensurada pelo método de Wilhelmy. Os canais radiculares instrumentados foram divididos aleatoriamente em grupos para receberem irrigação final com $5 \mathrm{ml}$ de cada solução a ser testada, por 1 minuto de aplicação. A concentração de cálcio foi avaliada por meio de espectrometria de absorção atômica. A incorporação de tensoativos reduziu os valores de tensão superficial de todas as soluções testadas, em aproximadamente 50\%. Entretanto, nenhuma das soluções com a tensão superficial reduzida pela adição do tensoativo foi capaz de quelar mais íons cálcio dos canais radiculares que suas fórmulas equivalentes, puras.

NAKASHIMA; TERATA ${ }^{109}$, em 2005, analisaram a influência da remoção da smear layer da dentina, por meio da aplicação de uma solução de EDTA a 3\% com $\mathrm{pH}$ modificado $(\mathrm{pH}=9,0)$, sobre a eficácia de três agentes antimicrobianos (tricresol formalina, fenol, hidróxido de cálcio). A avaliação do efeito antimicrobiano foi realizada pelo método de difusão em ágar com algumas modificações, por meio da mensuração dos halos de inibição. As cepas utilizadas foram Streptococcus intermedius e Candida albicans. Nos grupos que não receberam a irrigação com EDTA, não foram observados halos de inibição, enquanto que nos grupos onde utilizou-se a solução de EDTA, independente do agente antimicrobiano empregado, halos de inibição foram observados. 
ZEHNDER et al. ${ }^{191}$, em 2005, analisaram as interações do ácido cítrico e do EDTA com a solução de hipoclorito de sódio. Outras soluções quelantes foram simultâneamente avaliadas como possíveis alternativas: trifosfato de sódio (STP), ácido amino tris etilenofosfórico (ATMA), e 1-hidroxietilideno-1, 1-bifosfonato (HEBP). $\mathrm{O}$ teor de cloro nas associações quelante-hipoclorito foi avaliado. Todas as soluções quelantes com exceção do HEBP e do STP levaram à perda imediata e quase total do teor de cloro. A espectrometria de absorção atômica e a avaliação por meio da microscopia eletrônica de varredura das paredes dos canais radiculares instrumentados demonstraram que a solução de hipoclorito de sódio não provocou qualquer efeito negativo na capacidade dos agentes quelantes em promover a quelação dos íons cálcio da dentina. O STP apresentou uma capacidade quelante insatisfatória. A associação do ácido cítrico e do EDTA com o hipoclorito de sódio interferiu negativamente no efeito antimicrobiano deste último, enquanto que 0 HEBP, não.

NANDINI; VELMURUGAN; KANDASWAMY ${ }^{110}$, em 2006, avaliaram a eficácia do ácido cítrico a $10 \%$ e EDTA a $17 \%$, na remoção de medicamentos à base de hidróxido de cálcio (Metapex ${ }^{\circledR}$ e hidróxido de cálcio PA + água destilada) dos canais radiculares. Após sete dias, os canais contendo os medicamentos foram irrigados com ácido cítrico ou EDTA, sob agitação ultra-sônica. Por meio de tomografias computadorizadas, os autores verificaram que o ácido cítrico foi mais eficaz que o EDTA, na remoção do Metape ${ }^{\circledR}$ dos canais radiculares. O EDTA foi excelente na remoção do hidróxido de cálcio $P A$, em água destilada.

PÉREZ-HEREDIA; FERRER-LUQUE; GONZÁLEZ-RODRÍGUEZ ${ }^{130}$, em 2006, estudaram a capacidade de limpeza do ácido cítrico a $15 \%$, do EDTA a $15 \%$, e do ácido ortofosfórico a $5 \%$, associados ao hipoclorito de sódio a $5,25 \%$, em canais instrumentados manualmente ou por meio de sistema rotatório. A solução de hipoclorito de sódio a $5,25 \%$, isoladamente, foi utilizada como controle. As paredes dos canais instrumentados foram analisadas por meio de microscopia eletrônica de varredura e fotomicrografias dos terços cervical, médio e apical, foram realizadas. Escores foram utilizados para avaliar a presença de debris e da smear layer. Os resultados demonstraram que o ácido cítrico, o EDTA e o ácido ortofosfórico, associados ao hipoclolito de sódio, foram eficazes na eliminação da smear layer e 
dos debris. Em relação à técnica de instrumentação empregada, não foram observadas diferenças estatisticamente significantes. A solução de hipoclorito de sódio, isoladamente, não foi eficaz na eliminação da smear layer ou dos debris.

GONZÁLEZ-LÓPEZ et al. $^{70}$, em 2006, mensuraram a capacidade de desmineralização do ácido cítrico a 10 e a 20\%, e do EDTA a 17\%, isolados ou associados à clorexidina a 1\%. Espécimes de dentina bovina foram preparados e imersos em $25 \mathrm{ml}$ das soluções a serem estudadas. Após 3, 10 ou 15 minutos de imersão, a concentração de cálcio foi quantificada por meio de espectrometria de absorção atômica. Os resultados demonstraram que o efeito desmineralizador foi diretamente proporcional ao tempo de imersão, porém, sem diferença estatisticamente significante entre os tempos utilizados. A adição da clorexidina a $1 \%$ não afetou a capacidade de desmineralização das soluções (ácido cítrico e EDTA). Nos três primeiros minutos, mais íons cálcio foram obtidos com o uso da solução de EDTA a $17 \%$.

GIARDINO et al. ${ }^{65}$, em 2006, compararam a tensão superficial de quatro agentes irrigantes de canais radiculares (EDTA a 17\%, Cetrexidin ${ }^{\circledR}$, Smear Clear $^{\circledR} \mathrm{e}$ hipoclorito de sódio a 5,25\%) com a tensão superficial do MTAD e do Tetraclean ${ }^{\circledR}$, ambos, produtos comerciais compostos por um antibiótico, ácido cítrico e um tensoativo. A tensão superficial foi mensurada por meio de um analisador dinâmico de ângulo de contato, pela técnica de Wilhelmy. As soluções de hipoclorito de sódio e de EDTA apresentaram os maiores valores de tensão superficial, enquanto que, o

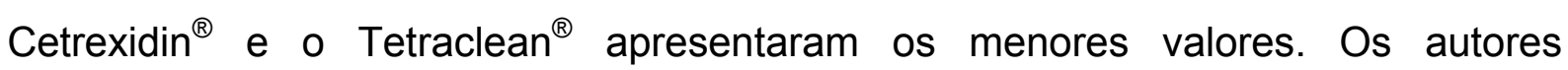
ressaltam, ainda, que ambos os novos produtos, MTAD e Tetraclean ${ }^{\circledR}$, são capazes de remover a smear layer e, graças a sua baixa tensão superficial, entram em íntimo contato com as paredes dos canais radiculares, permitindo uma maior penetração nos túbulos dentinários.

GRANDE et al. ${ }^{71}$, em 2006, analisaram a interação do hipoclorito de sódio com a solução de EDTA, por meio de ressonância magnética nuclear. Os resultados demonstraram que a reação do hipoclorito de sódio com a solução de EDTA leva a uma degradação muito lenta, porém, progressiva desta última. Os autores concluíram que a irrigação final do canal radicular com hipoclorito de sódio não é 
capaz de limitar o efeito quelante da solução de EDTA, num período de tempo clinicamente realista.

TAY et al. ${ }^{170}$, em 2006, examinaram, por meio de microscopia eletrônica de transmissão, a estrutura da dentina instrumentada, tendo o hipoclorito de sódio como agente irrigante, e irrigação final com: água destilada (controle positivo), EDTA a $17 \%$ (controle negativo) ou MTAD (Biopure ${ }^{\circledR}$ ). A irrigação final com EDTA a $17 \%$ ou com o MTAD removeu completamente a smear layer de 2 a $5 \mu \mathrm{m}$ de espessura, produzida pelo preparo mecânico dos canais radiculares. A ação de ambas as soluções quelantes resultaram na exposição de áreas de matriz colágena desmineralizada ao redor dos túbulos dentinários e da dentina erodida, sendo que a ação da solução MTAD ( $\mathrm{pH}=1,83)$ foi mais agressiva que a do EDTA.

QING et al. ${ }^{137}$, em 2006, avaliaram a capacidade de limpeza e a microdureza dentinária proporcionada pela irrigação de canais radiculares com a solução experimental strong acid eletrolitic water (SAEW - água eletrolítica ácido forte). Foi realizada a instrumentação dos canais radiculares com limas tipo $K$, pela técnica step-back convencional. A irrigação foi feita empregando-se hipoclorito de sódio a $5,25 \%$ e: água destilada, peróxido de hidrogênio a 3\%, solução experimental SAEW ou EDTA a 15\%. Espécimes foram preparados para o exame em microscópio eletrônico de varredura e para avaliação da microdureza Vickers. Quanto à capacidade de limpeza, os resultados demonstraram que a combinação hipoclorito de sódio + SAEW, foi equivalente ao hipoclorito + EDTA a 15\%. Quando o SAEW foi utilizado por 1 minuto, sob agitação ultra-sônica, não foram observadas reduções na microdureza dentinária.

KUM et al. ${ }^{88}$, em 2006, avaliaram, comparativamente, a qualidade e quantidade de smear layer formada pela ação de dois instrumentos rotatórios de diferentes fabricantes (K3 e ProFile) durante o preparo do terço apical de canais radiculares curvos (entre 30 e $35^{\circ}$ de curvatura). Todos os canais foram instrumentados até o diâmetro $n^{\circ} 35$, utilizando-se o Glyde File Prep ${ }^{\circledR}$ como lubrificante, e hipoclorito de sódio a 1\% como solução irrigante. Após o preparo, as raízes foram partidas longitudinalmente, e o terço apical dos canais radiculares foi examinado por meio de microscopia eletrônica de varredura. Escores foram estabelecidos para se determinar a quantidade de smear layer acumulada. Ambos 
os instrumentos testados deixaram as paredes recobertas com smear layer, porém, o instrumento K3 limpou melhor que o ProFile, as paredes do terço apical dos canais radiculares curvos.

KHADEMI; YAZDIZADEH; FEIZIANFARD ${ }^{86}$, em 2006, determinaram, in vitro, o diâmetro mínimo do preparo apical necessário para a penetração das soluções irrigantes, de forma que fosse possível a eliminação de debris e da smear layer do terço apical de canais radiculares instrumentados. Raízes mesiais de molares inferiores humanos foram instrumentadas pela técnica crown-down, até a lima memória de número $20,25,30$ ou 35 , empregando-se $2 \mathrm{ml}$ de hipoclorito de sódio (NaOCl) a 5,25\%, a cada troca de instrumento. Após a irrigação final com $5 \mathrm{ml}$ de EDTA a $17 \%$ por 5 minutos, seguido de $5 \mathrm{ml}$ de $\mathrm{NaOCl}$ a $5,25 \%$ por 5 minutos, a remoção de debris e de smear layer do terço apical dos canais radiculares foi avaliada por meio de microscopia eletrônica de varredura. Com base nos resultados obtidos, os autores concluíram que o diâmetro mínimo do preparo, necessário para a penetração das soluções irrigantes no terço apical dos canais radiculares, foi equivalente ao de uma lima número 30.

DE DEUS et al. ${ }^{42}$, em 2006, examinaram, por meio de microscopia de força atômica, em tempo real, as alterações na superfície dentinária durante a desmineralização, e avaliaram, qualitativamente, o efeito do EDTA a 17\%, EDTA-C a 17\% e do ácido cítrico a 10\%. Discos cilíndricos, de 5 milímetros de espessura, foram obtidos por meio de cortes transversais realizados ao nível da junção cemento-esmalte de caninos. Um procedimento metalográfico padronizado foi realizado para o preparo das superfícies dentinárias para a observação. Após a irrigação com EDTA, EDTA-C ou ácido cítrico, imagens topográficas foram obtidas durante o processo de desmineralização da dentina, permitindo a observação, em tempo real. Dois observadores estabeleceram escores por meio de um método duplo-cego. Os resultados evidenciaram que o ácido cítrico foi a substância mais eficaz na promoção da desmineralização da superfície dentinária examinada. Segundo os autores, a metodologia desenvolvida para a observação em tempo real da superfície dentinária é viável para avaliar a sua demineralização por ação de agentes quelantes. 
3 - PROPOSIČ̃̃O 


\section{3 - PROPOSIÇÃO}

O objetivo deste estudo foi avaliar, in vitro, a limpeza das paredes dos canais radiculares instrumentados e a permeabilidade dentinária, após o uso da solução de EGTA isolada ou associada a tensoativos, em comparação a duas soluções controle: água destilada (controle negativo) e EDTA (controle positivo). 
4 - MATERIAL E MÉTODOS 


\section{MATERIAL E MÉTODOS}

Este estudo foi realizado em duas etapas distintas. Uma avaliou a capacidade de remoção da smear layer de algumas soluções, por meio de microscopia eletrônica de varredura (MEV). Na outra, foi avaliada a permeabilidade dentinária, após o uso destas mesmas soluções, empregando-se um método histoquímico.

Para a realização de todo o experimento, foram utilizados 50 incisivos centrais superiores humanos, pertencentes ao arquivo de dentes da disciplina de Endodontia da FOB-USP, obtidos antes de 1996, mantidos em solução de formol a $10 \%$, até o momento do experimento.

\section{1 - PREPARO DAS SOLUÇÕES IRRIGANTES}

As soluções utilizadas foram aviadas no laboratório de Química da Faculdade de Biomedicina da Universidade de Franca, São Paulo (UNIFRAN).

A solução de EDTA foi preparada de acordo com a fórmula proposta por ØSTBY (1957). Em um béquer para $200 \mathrm{ml}$ foram pesados 17 gramas do sal dissódico do ácido etilenodiaminotetracético (Merck KGaA, Darmstadt, Alemanha), aos quais foram adicionados $100 \mathrm{ml}$ de água destilada e deionizada.

A solução de EGTA foi aviada a partir do ácido etileno glicol bis ( $\beta$-aminoetil-eter)-N,N,N',N'-tetracético, de procedência belga (ACROS Organics, Geel, Bélgica). Em um béquer para 200ml foram pesados 15 gramas do ácido (EGTA), aos quais foram adicionados $100 \mathrm{ml}$ de água destilada e deionizada.

Em outro béquer, este processo foi repetido. Após o preparo da solução, acrescentou-se 0,1 por cento de Cetavlon $^{\circledR}$, tensoativo catiônico derivado do amônio quaternário (brometo cetiltrimetilamônio) (Merck KGaA, Darmstadt, Alemanha), obtendo-se a solução experimental denominada EGTA-C.

A solução experimental EGTA-T foi preparada colocando-se 15 gramas de EGTA em uma proveta graduada de $200 \mathrm{ml}$, e acrescentando-se o tensoativo 
aniônico, Tergensol ${ }^{\circledR}$ (Lauril dietilenoglicol éter sulfato de sódio a 1,25\% - INODON Laboratório, Porto Alegre, RS, Brasil), até completar $100 \mathrm{ml}$. As soluções aviadas foram agitadas com um bastão de vidro, gotejando-se, lentamente, hidróxido de sódio $5 \mathrm{~N}$ (Merck KGaA, Darmstadt, Alemanha), até ser obtido pH 7,3, aferido por meio de um pH-meter (Digimed, modelo DMPH - 2).

Em seguida, as mesmas foram filtradas em papel-filtro e colocadas em um recipiente plástico, dotado de batoque e tampa, sendo, posteriormente, armazenadas em local fresco e isento de luz, até o momento do uso.

\section{2 - AVALIAÇÃO DA CAPACIDADE DE LIMPEZA DAS SOLUÇÕES}

Após a raspagem das superfícies externas, eliminando-se restos orgânicos e qualquer outro material aderido, vinte e cinco dentes daqueles cinquenta previamente selecionados foram separados e lavados em água corrente por 24 horas.

Por meio de radiografias tomadas no sentido proximal do dente, foi avaliada a morfologia interna e verificada a ausência de obstruções, condição necessária para o emprego da metodologia proposta.

Após a cirurgia de acesso aos canais, foi realizada a remoção dos remanescentes pulpares dos canais, com auxílio de uma lima tipo Hedströem $\mathrm{n}^{0} 15$. Em seguida, foi realizada a odontometria, com uma lima tipo $\mathrm{K} \mathrm{n}^{\circ} 10$, introduzida no canal até alcançar o forame apical. A partir daí, por visão direta do forame, a lima foi recuada um milímetro o que possibilitou estabelecer o comprimento real de trabalho (CRT), $1 \mathrm{~mm}$ aquém do forame apical anatômico.

Os canais foram instrumentados manualmente pela técnica step back, com limas tipo K. A partir da lima que se adaptou ao diâmetro anatômico do canal, foram utilizadas mais três limas de numeração ascendente, para a instrumentação da porção apical no CRT previamente determinado, e quatro limas para a realização do escalonamento programado (recuo de $1 \mathrm{~mm}$ ), sempre irrigando o canal com $3 \mathrm{~mL}$ de hipoclorito de sódio $2 \%$, por meio de cânulas de calibre $25 X 4$, a cada troca de 
instrumento, e realizando-se a recapitulação com a lima memória, durante o escalonamento. O calibre da lima memória esteve entre 45 e 50, ao final da instrumentação.

Terminada a instrumentação dos canais, os dentes foram, então, divididos em cinco grupos. No Grupo I, os canais instrumentados não foram irrigados novamente (controle negativo). No grupo II, os canais foram irrigados com $10 \mathrm{ml}$ de EGTA 15\% pH 7,3. No grupo III, com 10ml de EGTA 15\% + Cetavlon $^{\circledR}$ (EGTA-C), pH 7,3. No grupo IV, com $10 \mathrm{ml}$ de EGTA $15 \%$ + Tergensol $^{\circledR}$ (EGTA-T), pH 7,3. No grupo $\mathrm{V}$, com $10 \mathrm{ml}$ de EDTA $17 \%$, pH 7,3 (Controle positivo). Nos grupos II ao V, as soluções irrigadoras permaneceram no canal por 5 minutos cada.

Em seguida, os canais receberam irrigação final com $10 \mathrm{ml}$ de água destilada e, então, foram secos por aspiração e com cones de papel de diâmetros compatíveis com os diâmetros cirúrgicos apicais, obtidos após a instrumentação do canal radicular (diâmetro da lima memória).

Após o selamento do acesso coronário com silicona de condensação, com um disco diamantado (KG Sorensen, Barueri, São Paulo, Brasil), dupla face e em baixa rotação, foram realizados sulcos longitudinais percorrendo toda a extensão das faces vestibular e lingual dos dentes, cuidando sempre para não atingir o canal radicular.

Com o auxílio de um cinzel bi-biselado e um martelo cirúrgico, os dentes foram fraturados longitudinalmente de modo a deixar exposta toda a extensão do canal radicular, obtendo-se, assim, duas hemipartes de cada dente. Estas hemipartes foram montadas em bases metálicas (Stubs) e levadas ao metalizador Balzer $^{\circledR}$, modelo MED 010. Os espécimes metalizados foram, então, levados ao microscópio eletrônico de varredura ZEISS ${ }^{\circledR}$, modelo DSM 940 A (NAP/MEPAESALQ/USP) para observação da superfície dentinária dos canais radiculares.

A observação ao microscópio eletrônico de varredura foi realizada após dividir-se a porção radicular em terços: cervical, médio e apical. O exame microscópico foi feito, inicialmente, com pequenos aumentos de imagem, para localização das áreas mais representativas dos eventos observados. Após a determinação destas áreas, a observação foi realizada com aumento de 1000x, o 
que permitiu uma visão da área em questão sem perda de detalhes. Fotomicrografias digitais daquelas regiões mais representativas dos terços cervical, médio e apical do canal radicular foram obtidas, com o auxílio do programa DSM Image Transfer v.72 - LEO e salvas em CD-ROM, no formato TIF.

Para quantificar a capacidade de remoção da smear layer, promovida por cada solução irrigadora estudada, uma grade quadriculada contendo 288 quadrantes, foi digitalmente confeccionada e sobreposta a cada fotomicrografia obtida. Com o auxílio do programa ImageTool 3.0 (UTHSCSA, San Antonio, EUA), foi realizada a contagem do número de quadrantes que se encontravam sobrepostos às áreas limpas (livres de smear layer) (Figura 1). Deste modo, foi possível estabelecer a porcentagem de limpeza da superfície dentinária e, conseqüentemente, a capacidade de cada solução irrigadora de remover a smear layer. 


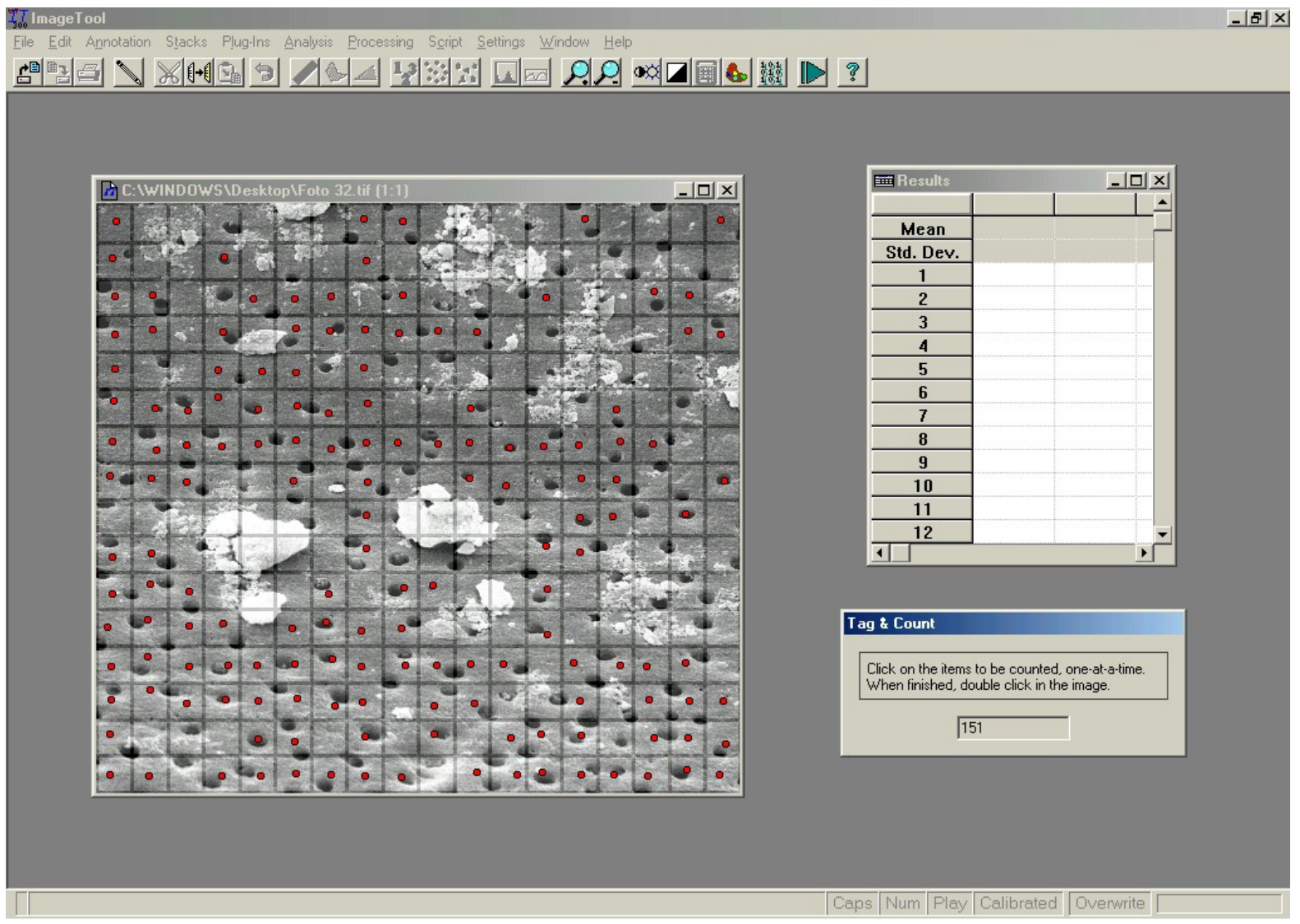

Figura 1 - Interface do programa ImageTool 3.0, utilizado para contagem dos quadrantes livres de smear layer e detritos.

Os dados obtidos foram inseridos no programa GraphPad Prism versão 4.0 para Windows (GraphPad Software Inc., San Diego, Califórnia, E.U.A.) e submetidos à análise estatística. 


\section{3 - AVALIAÇÃO DA PERMEABILIDADE DENTINÁRIA}

Os 25 dentes restantes, dos 50 selecionados anteriormente, foram lavados em água corrente por 24 horas e armazenados individualmente em recipientes de plástico, contendo água destilada.

As coroas de todos os dentes foram removidas na junção amelo-cementária, por meio de secção com disco diamantado em baixa rotação e refrigerado com água. Os remanescentes pulpares radiculares foram removidos com auxilio de uma lima tipo Hedströem $n^{\circ} 15$.

A odontometria foi realizada seguindo o mesmo critério utilizado anteriormente. O comprimento real de trabalho (CRT) foi estabelecido a $1 \mathrm{~mm}$ aquém do forame apical anatômico.

Os dentes foram, então, divididos aleatoriamente em 5 grupos de 5 elementos cada.

Os canais foram instrumentados manualmente pela técnica step back com limas tipo K (Dentsply/Maillefer, Suiça). A partir da lima que se adaptou ao diâmetro anatômico do canal, foram utilizadas mais 3 limas para a confecção do batente apical, no CRT previamente determinado, e mais 4 limas para a realização do escalonamento programado (recuo de $1 \mathrm{~mm}$ ). Durante a instrumentação, os canais foram irrigados com $3 \mathrm{ml}$ da solução em teste, a cada troca de instrumento. Foi realizada a recapitulação com a lima memória, durante o escalonamento.

No Grupo I, a solução irrigadora utilizada durante a instrumentação dos canais radiculares foi a água destilada e deionizada (grupo controle). No grupo II, os canais foram irrigados com EGTA 15\%, pH 7,3. No grupo III, foi utilizada a solução de EGTA $15 \%$ + Cetavlon $^{\circledR}$ (EGTA-C), pH 7,3. No grupo IV, a solução de EGTA 15\% + Tergensol $^{\circledR}$ (EGTA-T), pH 7,3 e no grupo V, a solução de EDTA 17\%, pH 7,3.

Concluída esta etapa, os canais foram irrigados com $10 \mathrm{ml}$ de água destilada com aspiração concomitante. Então, os dentes foram secos com um jato de ar e os canais radiculares secos com cones de papel absorvente para receberem os reagentes químicos para o ensaio histoquímico, para a análise da permeabilidade dentinária. 
Em seguida, as superfícies externas das raízes dos dentes de todos os grupos foram impermeabilizadas com éster de cianoacrilato (Super Bonder ${ }^{\circledR}$, Loctite, Brasil) com exceção de $2 \mathrm{~mm}$ apicais e da superfície cervical. Após a impermeabilização o forame apical foi ultrapassado com uma lima tipo $K \mathrm{n}^{\circ} 15$, para confirmar a ausência de obstruções.

Após a secagem do cianoacrilato, os dentes foram submetidos ao ensaio histoquímico para evidenciar a permeabilidade dentinária. A técnica utilizada para avaliação da permeabilidade foi a originalmente proposta por FEIGL ${ }^{51}$, em 1958, e adaptada para experimento em dentina segundo PÉCORA ${ }^{122}$, em 1985, com algumas modificações. Na Tabela 1, observam-se os reagentes utilizados no experimento.

Tabela 1 - Reagentes empregados na realização do experimento para análise da permeabilidade dentinária.

\section{Reagente Procedência Fórmula química}

Acido Rubeânico

Sulfato de cobre

Hidróxido de amônio
MERCK - Alemanha

MERCK - Alemanha

MERCK - Alemanha
$\mathrm{C}_{2} \mathrm{H}_{4} \mathrm{~N}_{2} \mathrm{~S}_{2}$

$\mathrm{Cu} \mathrm{SO} 45 \mathrm{H}_{2} \mathrm{O}$

$\mathrm{NH}_{3} \mathrm{OH}$

O preparo da solução de sulfato de cobre foi realizado da seguinte forma. Um grama de sulfato de cobre foi dissolvido em $100 \mathrm{~mL}$ de água destilada. A esta solução foram adicionados $25 \mathrm{~mL}$ de hidróxido de amônio a 25\%. Para o preparo da solução alcoólica de ácido rubeânico, foi utilizado um grama de ácido rubeânico, diluído em $100 \mathrm{ml}$ de álcool etílico. Ambas as soluções foram preparadas momentos antes da realização do experimento.

Inicialmente, as raízes de cada grupo experimental, ainda protegidas com cianoacrilato, foram imersas na solução de sulfato de cobre recém preparada. Em uma perfuração na tampa do recipiente foi adaptada uma mangueira conectada à uma bomba de vácuo para a remoção do ar do interior dos canais radiculares. Essa ação teve aplicação efetiva por um período de 5 minutos. As raízes, ainda, 
permaneceram imersas na solução de sulfato de cobre por mais 25 minutos, totalizando um tempo de 30 minutos de imersão. Em seguida, as raízes foram removidas do recipiente e suas superfícies secas com toalha de papel absorvente. A solução foi removida do interior do canal radicular por aspiração e cones de papel absorvente, compatíveis com o diâmetro da lima memória correspondente, quando do preparo do batente apical. Imediatamente após este procedimento, em outro frasco semelhante ao primeiro utilizado, foi adicionada a solução de ácido rubeânico. Os mesmos procedimentos de imersão das raízes, realizados anteriormente, foram repetidos, assim, tanto o tempo de aplicação do vácuo como o tempo de permanência das raízes no ácido rubeânico, foram iguais aos aplicados com a solução de sulfato de cobre.

A bomba de vácuo, utilizada neste experimento foi da marca Tecnal ${ }^{\circledR}$, modelo TE-058 (Tecnal Equipamentos para Laboratórios, Piracicaba, São Paulo, Brasil), com uma pressão negativa de $600 \mathrm{~mm} \mathrm{Hg}$.

Para fixação da coloração obtida pela reação histoquímica, as raízes foram colocadas nos respectivos recipientes dotados de tampa (não perfurada), contendo uma gaze previamente umedecida com hidróxido de amônia.

Uma vez concluído o ensaio histoquímico, as raízes de todos os grupos experimentais foram seccionadas transversalmente, obtendo-se fragmentos com 0,5 $\mathrm{mm}$ de espessura dos terços cervical, médio e apical. Essas secções foram realizadas utilizando-se um disco diamantado de dupla face, adaptado a uma máquina de corte de baixa velocidade da marca Buehler ${ }^{\circledR}$, modelo Isomet $^{\mathrm{TM}}$ (Lake Bluff, Illinois, EUA) ajustada em 200 r.p.m. Durante os procedimentos de corte, o disco foi refrigerado com água. Para melhor controle desta operação, a raiz foi incluída em resina acrílica de rápida polimerização, sendo, então, presa no dispositivo de fixação do aparelho.

Os fragmentos obtidos foram, então, desgastados com lixas (Norton, Brasil) de numeração 320, 400, 500 e 600, para planificação da superfície superior e inferior e redução da espessura dos fragmentos para $0,20 \mathrm{~mm}$, aproximadamente. Em seguida, foram lavados em água corrente por 24 horas.

Posteriormente, os fragmentos foram desidratados em álcool de concentrações ascendentes (70, 80, 96 e 100\%), pelo período de duas horas em 
cada concentração, depois, clarificados em Xilol (três banhos). Na seqüência, os fragmentos foram fotografados de forma padronizada (distância focal $3 \mathrm{~cm}$, ângulo de incidência de $90^{\circ}$ ) com uma câmera digital modelo Coolpix ${ }^{\circledR} 990$ (Nikon Corp., EUA) no modo macro.

Para calibragem das imagens, todos os fragmentos radiculares foram fotografados ao lado de uma régua endodôntica milimetrada.

Os fragmentos fotografados foram examinados em computador, com 0 auxílio do software Image Tool ${ }^{\circledR} 3.0$ (Figura 2).

Com o recurso calibrate spacial mesurements, no menu settings, foi mensurada, na imagem da régua, uma distância correspondente a $1 \mathrm{~mm}$. $O$ valor obtido foi, então, corrigido e, a partir daí, deu-se início à avaliação das áreas de interesse em cada fragmento obtido (recurso área no menu analysis). 


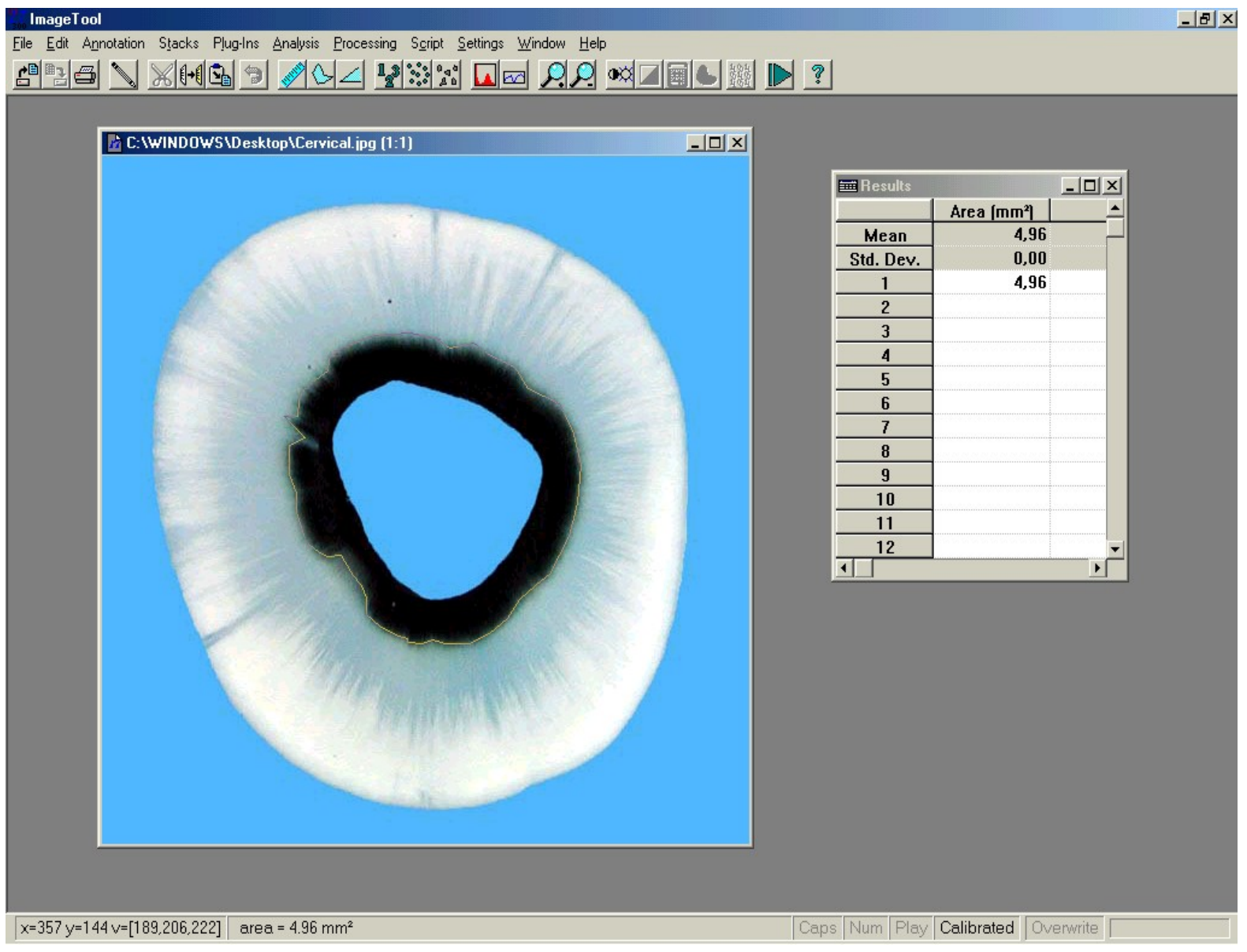

Figura 2 - Interface do programa ImageTool 3.0 utilizado para a análise da área de marcação com o complexo rubeanato de cobre. 
Para cada fragmento, foram tabelados três valores: um para o vazio dado pelo orifício do canal radicular (área da luz do canal); um para a área de dentina marcada pela reação do sulfato de cobre com o ácido rubeânico (rubeanato de cobre = mancha negra); e outro para a área total da dentina (área marcada e não marcada).

Nas situações onde a área marcada pelos reagentes não possibilitava uma delimitação precisa, foram feitas duas mensurações. Primeiramente, foi feita a medida da área de dentina completamente marcada pelos reagentes. Esta área era menor e mais próxima da luz do canal. Posteriormente, foi medida a área total de marcação, incluíndo a área de penetração dos reagentes em maior profundidade, porém irregular, onde era possível visualizar alguns túbulos dentinários não marcados. A partir destes dois valores foi obtida a média aritmética correspondente à área de marcação, utilizada para se determinar o grau de permeabilidade dentinária.

O parâmetro utilizado para estabelecer o grau de permeabilidade dentinária, foi a porcentagem de penetração dos íons cobre na dentina, marcada pela reação entre o sulfato de cobre e o ácido rubeânico. Para isso, foi aplicada a seguinte fórmula:

$$
\% \text { de penetração }=\frac{A-a}{A t-a} \times 100
$$

Onde "A" corresponde à área marcada pela penetração dos íons cobre na dentina, evidenciada pela reação com o ácido rubeânico; "a" corresponde à área da luz do canal; e "At" corresponde à área total da dentina do fragmento radicular.

Os valores obtidos foram anotados em uma tabela para, posteriormente, serem submetidos à analise estatística por meio do programa GraphPad Prism versão 4.0 . 
5 - RESULTADOS 


\section{5 - RESULTADOS}

\section{1 - CAPACIDADE DE LIMPEZA DAS SOLUÇÕES}

Os resultados da contagem preliminar do número de quadrantes que se encontravam sobrepostos às áreas limpas da superfície dentinária nas fotomicrografias realizadas por meio da microscopia eletrônica de varredura, estão expressos na Tabela 2.

Imagens representativas dos terços cervical, médio e apical dos dentes dos cinco grupos experimentais podem ser vistas nas figuras 3 a 7 .

Tabela 2 - Valores obtidos pela contagem do número de quadrantes limpos nas fotomicrografias (MEV).

\begin{tabular}{lccccc}
\hline \multirow{2}{*}{ TERÇOS } & \multicolumn{5}{c}{ SOLUÇÕES IRRIGADORAS } \\
\cline { 2 - 6 } & Água destilada & EGTA & EGTA-C & EGTA-T & EDTA \\
\hline \multirow{4}{*}{ Cervical } & 0 & 39 & 196 & 189 & 287 \\
& 0 & 8 & 191 & 217 & 284 \\
& 2 & 37 & 158 & 215 & 283 \\
Médio & 1 & 45 & 147 & 229 & 288 \\
& 0 & 52 & 94 & 267 & 287 \\
& 0 & 41 & 168 & 206 & 288 \\
& 1 & 50 & 139 & 201 & 287 \\
Apical & 0 & 31 & 219 & 255 & 284 \\
& 0 & 7 & 76 & 227 & 286 \\
& 0 & 28 & 89 & 221 & 283 \\
& 0 & 4 & 101 & 107 & 257 \\
\hline & 0 & 36 & 79 & 129 & 283 \\
& 0 & 22 & 93 & 174 & 280 \\
\hline
\end{tabular}

Número total de quadrantes da grade digitalmente confeccionada $(100 \%)=288$ quadrantes 

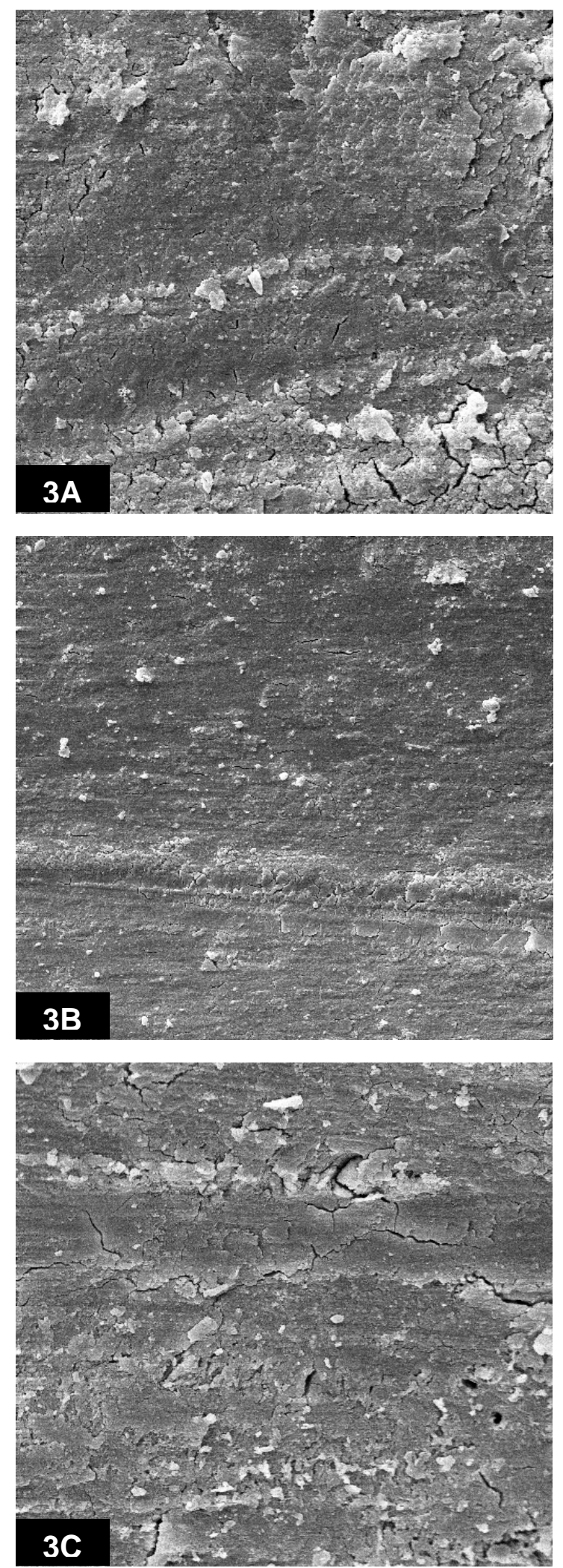

Figura 3 - Grupo I: Água destilada (1000x).

Fotomicrografias dos terços cervical $(A)$, médio (B) e apical (C). 

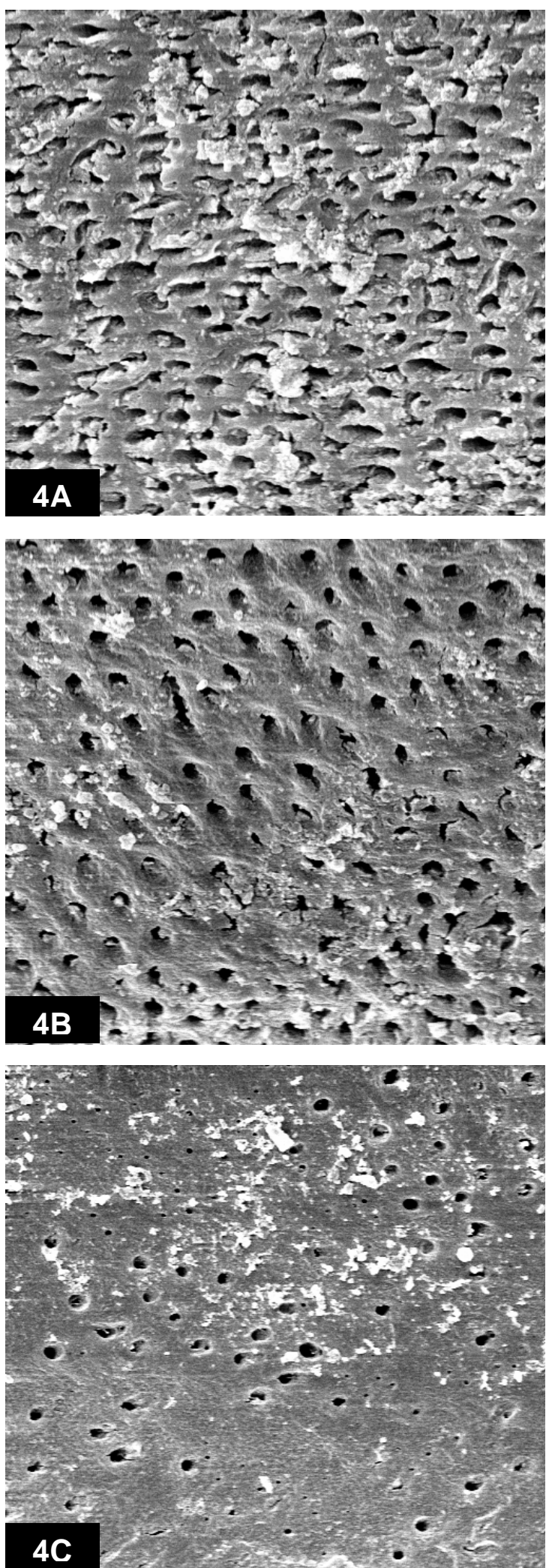

Figura 4 - Grupo II: EGTA a 15\% (1000x).

Fotomicrografias dos terços cervical (A), médio (B) e apical (C).

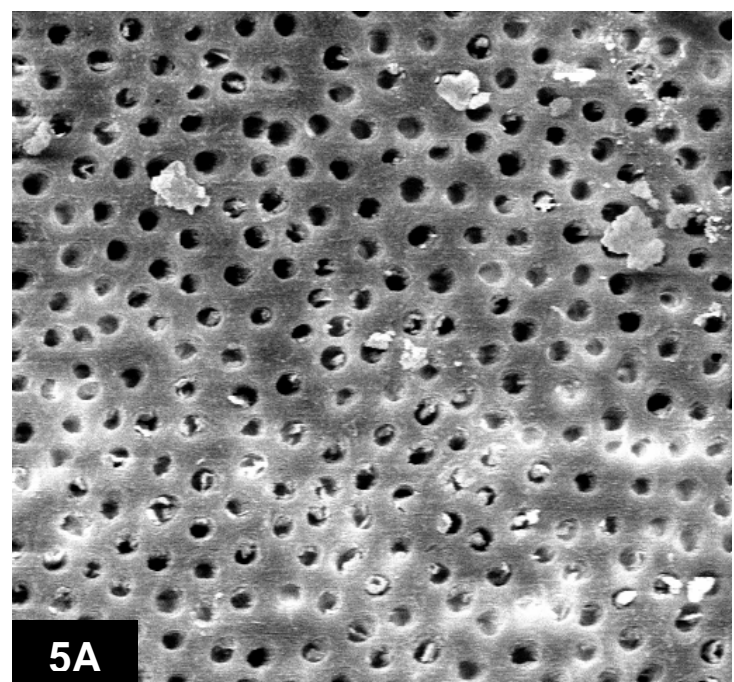

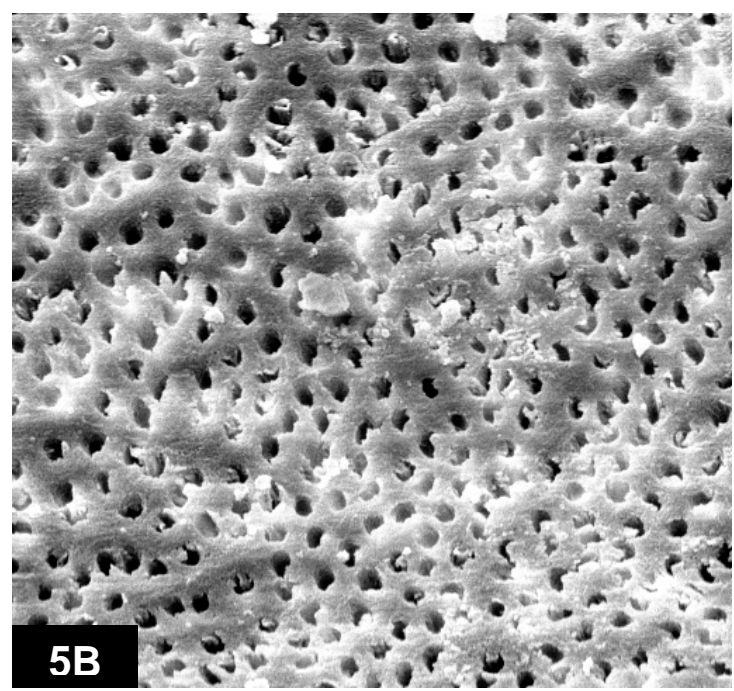

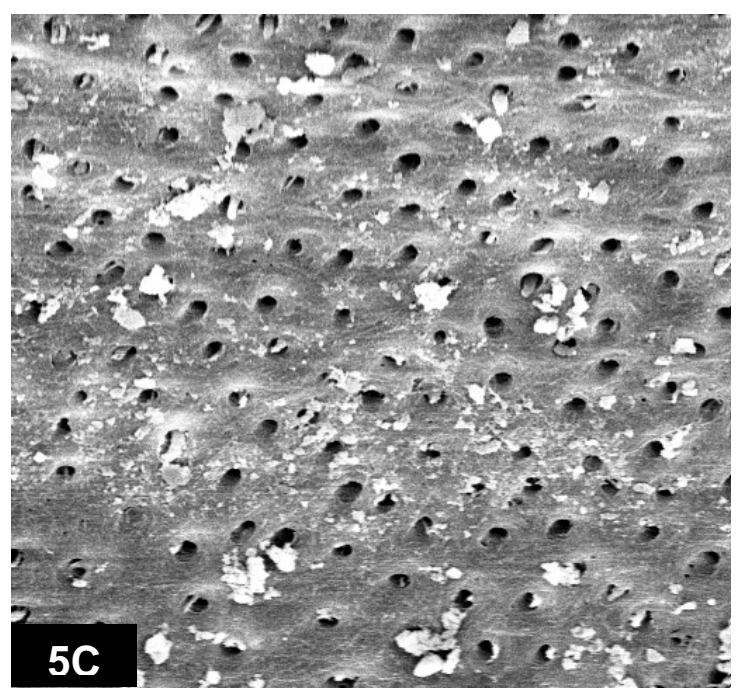

Figura 5 - Grupo III: EGTA-C a 15\% (1000x). Fotomicrografias dos terços cervical (A), médio (B) e apical (C). 

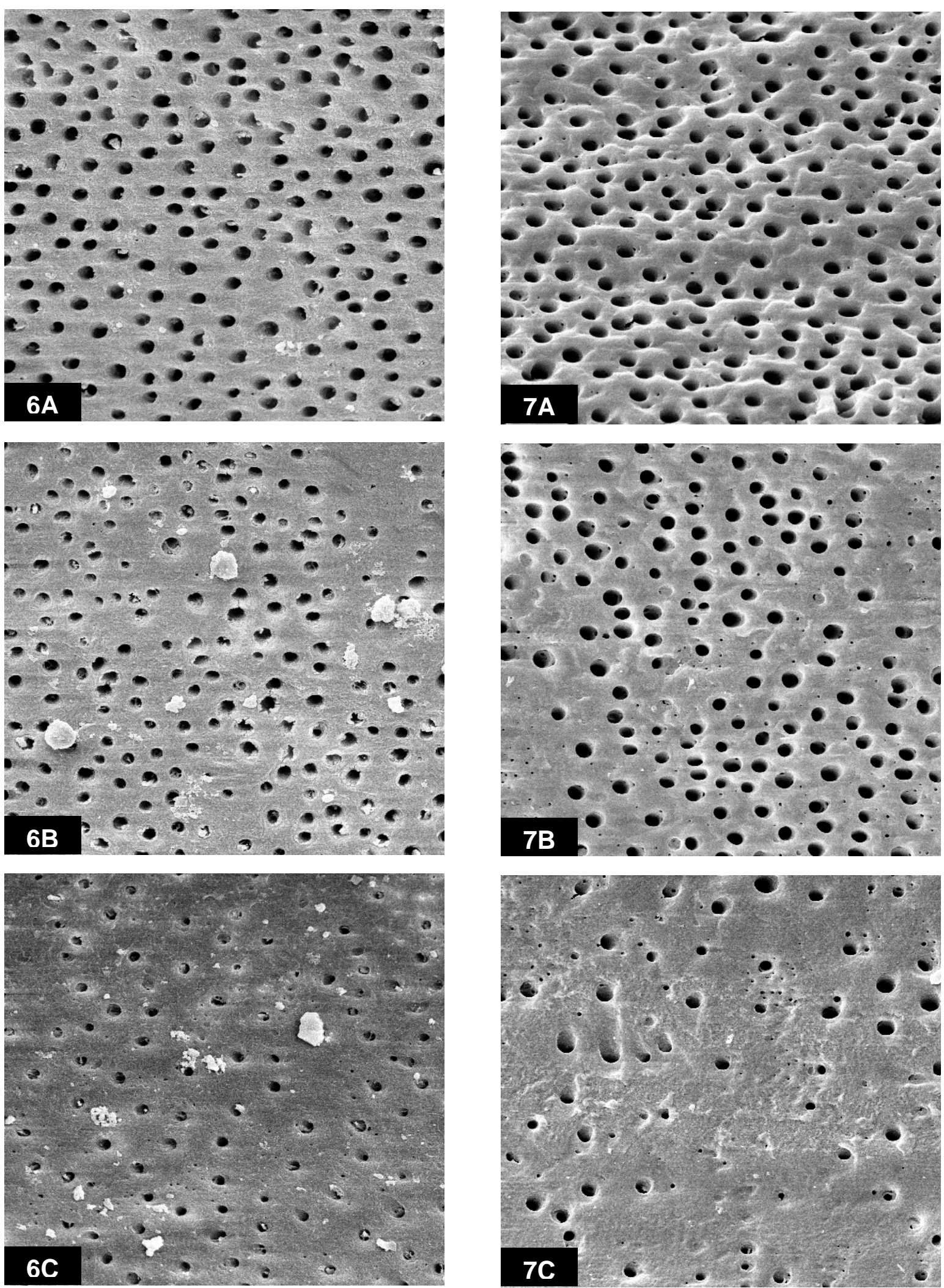

Figura 6 - Grupo IV: EGTA-T a 15\% (1000x). Fotomicrografias dos terços cervical (A), médio (B) e apical (C).

Figura 7 - Grupo V: EDTA a 15\% (1000x).

Fotomicrografias dos terços cervical (A), médio (B) e apical (C). 
A partir do número de quadrantes limpos foi possível calcular a porcentagem de limpeza da superfície dentinária dos canais radiculares instrumentados (Tabela 3).

Tabela 3 - Porcentagem de limpeza da superfície dentinária em função de cada solução irrigadora testada e cada terço radicular examinado - Média e desvio padrão.

\begin{tabular}{cccccc}
\hline \multirow{2}{*}{ TERÇO } & \multicolumn{5}{c}{ SOLUÇÕES IRRIGADORAS } \\
\cline { 2 - 6 } & Água destilada & EGTA & EGTA-C & EGTA-T & EDTA \\
\hline \multirow{2}{*}{ Cervical } & 0,00 & 13,54 & 68,05 & 65,62 & 99,65 \\
& 0,00 & 2,77 & 66,31 & 75,34 & 98,61 \\
& 0,69 & 12,84 & 54,86 & 74,65 & 98,26 \\
& 0,34 & 15,62 & 51,04 & 79,51 & 100,00 \\
Médio & 0,00 & 18,05 & 32,63 & 92,70 & 99,65 \\
& $X, 20 \pm 0,30$ & $X=12,56 \pm 5,83$ & $X=54,58 \pm 14,26$ & $X=77,56 \pm 9,86$ & $X=99,23 \pm 0,75$ \\
& 0,00 & 14,23 & 58,33 & 71,52 & 100,00 \\
& 0,34 & 17,36 & 51,73 & 69,79 & 99,65 \\
Apical & 0,00 & 10,76 & 76,04 & 88,54 & 98,61 \\
& 0,00 & 2,43 & 26,38 & 78,81 & 99,30 \\
& 0,00 & 9,72 & 30,90 & 76,73 & 98,26 \\
& $X, 06 \pm 0,15$ & $X=10,90 \pm 5,61$ & $X=48,68 \pm 20,40$ & $X=77,08 \pm 7,39$ & $X=99,16 \pm 0,72$ \\
& 0,00 & 1,38 & 35,06 & 37,15 & 96,52 \\
& 0,00 & 12,50 & 27,43 & 44,79 & 89,23 \\
& 0,00 & 7,63 & 32,29 & 60,41 & 98,26 \\
& 0,00 & 6,59 & 4,51 & 55,20 & 97,22 \\
& 0,00 & 14,93 & 20,48 & 61,45 & 88,19 \\
& $X, 00 \pm 0,00$ & $X=8,60 \pm 5,30$ & $X=23,95 \pm 12,20$ & $X=51,80 \pm 10,52$ & $X=93,88 \pm 4,77$ \\
\hline
\end{tabular}


Estes valores consistiram do produto fatorial de cinco soluções irrigadoras testadas (água destilada, EGTA, EGTA-C, EGTA-T e EDTA), três terços radiculares (cervical, médio e apical) e cinco repetições, totalizando 75 valores numéricos (5 × 3 x 5).

De posse dos valores da porcentagem de limpeza da superfície dentinária, realizou-se o teste estatístico preliminar de Bartlett, que verifica se as variâncias são homocedásticas, ou seja, se as variâncias são estatisticamente semelhantes ou não. Os resultados do teste de Bartlett para os fatores de variação "Soluções irrigadoras" e "Terços Radiculares" podem ser vistos na tabela 4.

Tabela 4 - Resultado do teste estatístico de Bartlett.

\begin{tabular}{lcc}
\hline Fatores de Variação & Soluções irrigadoras & Terços \\
\hline Valor estatístico de Bartlett & 140,3 & 0,3379 \\
Valor de P & $\mathrm{p}<0,0001$ & 0,8445 \\
Valor de P (Resumo) & $* * *$ & $\mathrm{~ns}$ \\
As variâncias diferem significativamente $(p<0,05)$ & Sim & Não \\
\hline
\end{tabular}

***: significante ao nível de $0,1 \%$

ns: não significante

Como o teste estatístico preliminar de Bartlett demonstrou haver diferença significante entre as variâncias para o fator de variação "soluções irrigadoras", primeiramente, tentou-se realizar a transformação dos dados amostrais. Após a transformação dos dados, e nova aplicação do teste de Bartlett, verificou-se que as varâncias continuavam a ser estatísticamente diferentes entre si. Por este motivo, indicou-se a estatística não-paramétrica a partir dos dados originais. O teste nãoparamétrico que melhor se adaptou ao modelo experimental foi o teste de KruskalWallis, por se tratar de um teste que permite a comparação de dados múltiplos e independentes. Os resultados deste teste estão dispostos na tabela 5. 
Tabela 5 - Resultado do teste de Kruskal-Wallis: Fator de variação "Soluções irrigadoras".

\begin{tabular}{lc}
\hline Fator de Variação & Soluções irrigadoras \\
\hline Número de grupos & 5 \\
Valor estatístico de Kruskal-Wallis & 68,62 \\
As médias variam significativamente? $(p<0,05)$ & Sim \\
Valor de P exato ou aproximado? & Aproximação Gaussiana \\
Valor de P & $p<0,001$ \\
Valor de P (resumo) & $* * *$
\end{tabular}

${ }^{\star * *}$ : significante ao nível de $0,1 \%$

O teste de Kruskal-Wallis mostrou haver diferença significante $(p<0,001)$ entre as soluções estudadas. Para identificar quais, dentre as soluções irrigadoras eram estatisticamente diferentes entre si, realizou-se o teste complementar de Dunn (Tabela 6).

Tabela 6 - Resultado do Teste de Dunn: Fator de variação "Soluções Irrigadoras".

\begin{tabular}{lclc}
\hline $\begin{array}{c}\text { Teste de Múltipla } \\
\text { Comparação de Dunn }\end{array}$ & $\begin{array}{c}\text { Diferença entre } a \\
\text { Soma dos Postos }\end{array}$ & Valor de P & Resumo \\
\hline Água vs EGTA & 15,80 & $\mathrm{p}>0,05$ & $\mathrm{~ns}$ \\
Água vs EGTA-C & 31,27 & $\mathrm{p}<0,001$ & $* * *$ \\
Água vs EGTA-T & 43,13 & $\mathrm{p}<0,001$ & $* * *$ \\
Água vs EDTA & 59,80 & $\mathrm{p}<0,001$ & $* * *$ \\
EGTA vs EGTA-C & 15,47 & $\mathrm{p}>0,05$ & $\mathrm{~ns}$ \\
EGTA vs EGTA-T & 27,33 & $\mathrm{p}<0,01$ & $* *$ \\
EGTA vs EDTA & 44,00 & $\mathrm{p}<0,001$ & ns \\
EGTA-C vs EGTA-T & 11,87 & $\mathrm{p}>0,05$ & $* *$ \\
EGTA-C vs EDTA & 28,53 & $\mathrm{p}<0,01$ & $\mathrm{~ns}$ \\
EGTA-T vs EDTA & 16,67 & $\mathrm{p}>0,05$ & \\
\hline
\end{tabular}

ns: não significante

**: significante ao nível de $1 \%$

${ }^{* * *}$ : significante ao nível de $0,1 \%$ 
O teste complementar de Dunn evidenciou não haver diferença estatisticamente significante entre o grupo controle negativo (água destilada) e o grupo tratado com EGTA $(p>0,05)$. Porém, o grupo controle negativo (água destilada) foi estatisticamente inferior aos grupos tratados com EGTA-C, EGTA-T e EDTA $(p<0,001)$.

O tratamento da dentina com a solução de EGTA-T, foi o único a obter resultados estatisticamente semelhantes aos obtidos com o uso do EDTA (controle positivo) $(p>0,05)$, que, por sua vez, apresentou os melhores resultados quanto à limpeza da superfície dentinária e, conseqüentemente, quanto à remoção da smear layer. Os resultados obtidos podem ser vistos na figura 8.

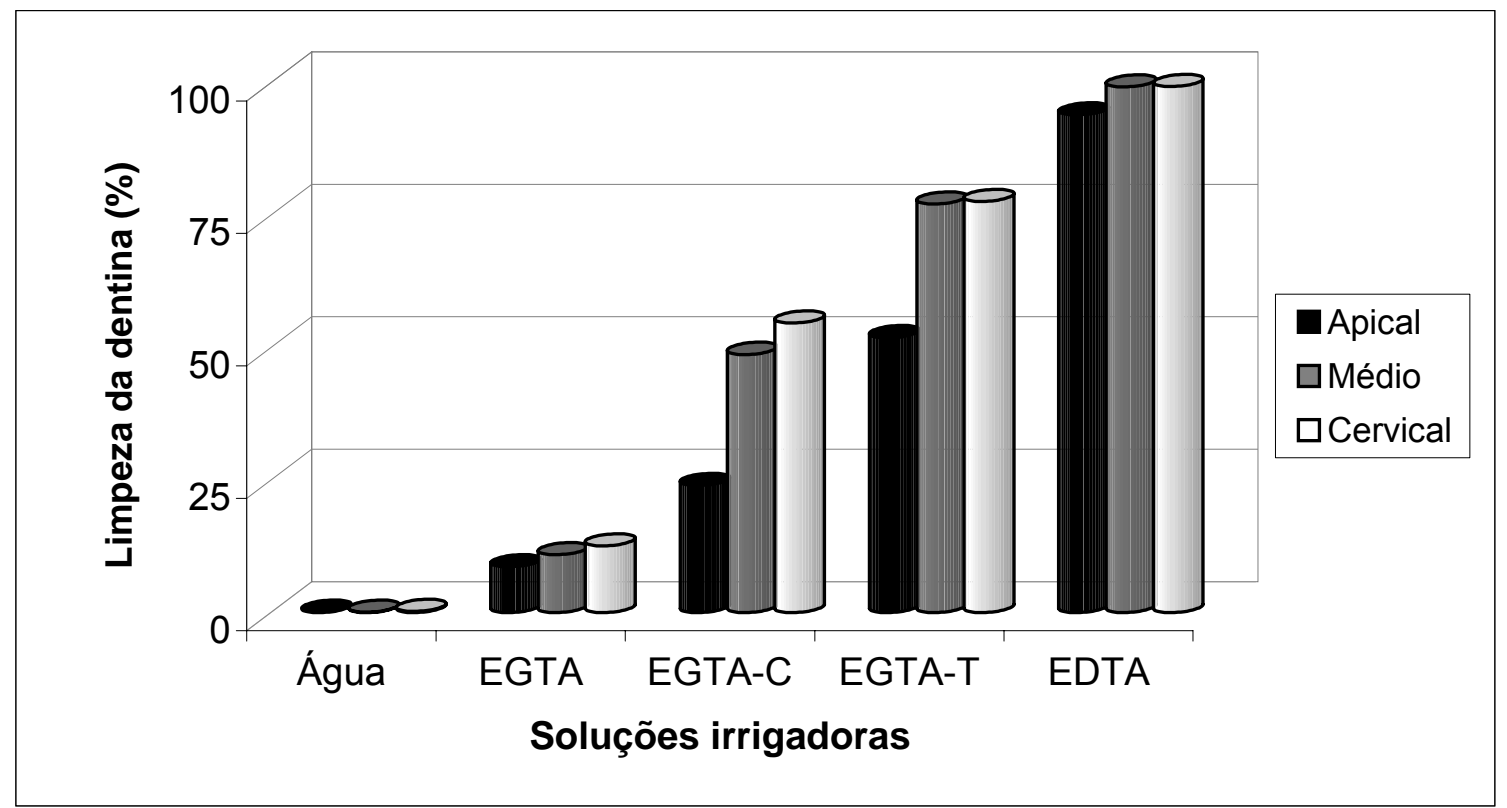

Figura 8 - Gráfico dos valores médios da porcentagem de limpeza dentinária em função de cada solução irrigadora testada e terço radicular examinado.

Em relação à análise do fator de variação "Terços Radiculares", o teste preliminar de Bartlett evidenciou não haver diferença significante entre as variâncias testadas $(p>0,05)$, o que permitiu a utilização de testes estatísticos paramétricos. O teste paramétrico que melhor se adaptou ao modelo experimental foi a análise de 
variância para dados múltiplos e vinculados (Repeated Measures ANOVA). Os resultados da análise de variância para o fator de variação "Terços Radiculares", estão dispostos nas tabelas 7 e 8.

Tabela 7 - Resultados da análise de variância: Fator de variação "Terços Radiculares".

\begin{tabular}{lc}
\hline Fator de Variação & Terços Radiculares \\
\hline Número de grupos & 3 \\
Valor de F & 15,95 \\
Valor de $\mathrm{R}^{2}$ & 0,3992 \\
Valor de P & $\mathrm{P}<0,0001$ \\
Valor de P (resumo) & $* * *$ \\
As médias diferem significativamente $(p<0,05)$ & $\mathrm{Sim}$
\end{tabular}
***: significante ao nível de $0,1 \%$

Tabela 8 - Resultados da análise de variância: Fator de variação "Terços Radiculares".

\begin{tabular}{lccc}
\hline Análise de Variância & $\begin{array}{c}\text { Soma dos } \\
\text { quadrados }\end{array}$ & $\begin{array}{c}\text { Graus de } \\
\text { Liberdade }\end{array}$ & Quadrados Médios \\
\hline Terços & 2578 & 2 & 1289 \\
Individual & 100700 & 24 & 4197 \\
Resíduo & 3879 & 48 & 80,82 \\
Total & 107200 & 74 & \\
\hline
\end{tabular}

Uma vez que a análise de variância demonstrou haver diferença estatisticamente significante $(p<0,0001)$, para identificar quais dentre os terços radiculares eram estatisticamente diferentes entre si, realizou-se o teste complementar de Tukey, entre as médias dos terços estudados (Tabela 9). 
Tabela 9 - Teste de Tukey: Fator de variação "Terços radiculares".

\begin{tabular}{lcccc}
\hline Teste de Tukey - Terços & Diferença média & $\mathrm{q}$ & Valor de P & Resumo \\
\hline Cervical vs Médio & 1,652 & 0,9188 & $\mathrm{p}>0,05$ & ns \\
Cervical vs Apical & 13,18 & 7,331 & $\mathrm{p}<0,001$ & $* * *$ \\
Médio vs Apical & 11,53 & 6,412 & $\mathrm{p}<0,001$ & $* * *$ \\
\hline
\end{tabular}

ns: não significante

***: significante ao nível de $0,1 \%$

O teste complementar de Tukey, de modo geral, evidenciou haver semelhança estatística entre o terço cervical e o terço médio $(p>0,05)$, sendo estes, diferentes estatisticamente do terço apical $(p<0,001)$, que apresentou os piores resultados quanto à limpeza da superfície dentinária. Entretanto, individualmente, as soluções irrigadoras apresentaram resultados distintos, que podem ser vistos na Tabela 10.

Tabela 10 - Teste de Tukey: análise do comportamento individual de cada solução nos diversos terços radiculares estudados.

\begin{tabular}{|c|c|c|c|c|c|}
\hline $\begin{array}{c}\text { Soluções } \\
\text { Irrigadoras }\end{array}$ & $\begin{array}{l}\text { Teste comparações } \\
\text { Múltiplas de Tukey }\end{array}$ & $\begin{array}{l}\text { Diferença entre } \\
\text { as médias }\end{array}$ & q & Valor de P & Resumo \\
\hline \multirow{3}{*}{$\begin{array}{c}\text { Água } \\
\text { Destilada }\end{array}$} & Cervical vs Médio & 0,138 & 1,452 & $P>0.05$ & ns \\
\hline & Cervical vs Apical & 0,206 & 2,167 & $P>0.05$ & ns \\
\hline & Médio vs Apical & 0,068 & 0,715 & $P>0.05$ & ns \\
\hline \multirow{3}{*}{ EGTA } & Cervical vs Médio & 1,664 & 0,592 & $P>0.05$ & ns \\
\hline & Cervical vs Apical & 3,958 & 1,409 & $P>0.05$ & ns \\
\hline & Médio vs Apical & 2,294 & 0,816 & $P>0.05$ & ns \\
\hline \multirow{3}{*}{ EGTA-C } & Cervical vs Médio & 5,902 & 1,292 & $P>0.05$ & ns \\
\hline & Cervical vs Apical & 30,62 & 6,706 & $P<0.01$ & $* *$ \\
\hline & Médio vs Apical & 24,72 & 5,414 & $P<0.05$ & * \\
\hline \multirow{3}{*}{ EGTA-T } & Cervical vs Médio & 0,486 & 0,177 & $P>0.05$ & ns \\
\hline & Cervical vs Apical & 25,76 & 9,399 & $P<0.001$ & $* * *$ \\
\hline & Médio vs Apical & 25,28 & 9,221 & $P<0.001$ & $* * *$ \\
\hline \multirow{3}{*}{ EDTA } & Cervical vs Médio & 0,070 & 0,056 & $P>0.05$ & ns \\
\hline & Cervical vs Apical & 5,350 & 4,313 & $P<0.05$ & * \\
\hline & Médio vs Apical & 5,280 & 4,257 & $P<0.05$ & * \\
\hline
\end{tabular}

ns: não significante

*: significante ao nível de $5 \%$

**: significante ao nível de $1 \%$

${ }^{* * *}$ : significante ao nível de $0,1 \%$ 
Os resultados obtidos podem ser visualizados mais claramente na Figura 9.

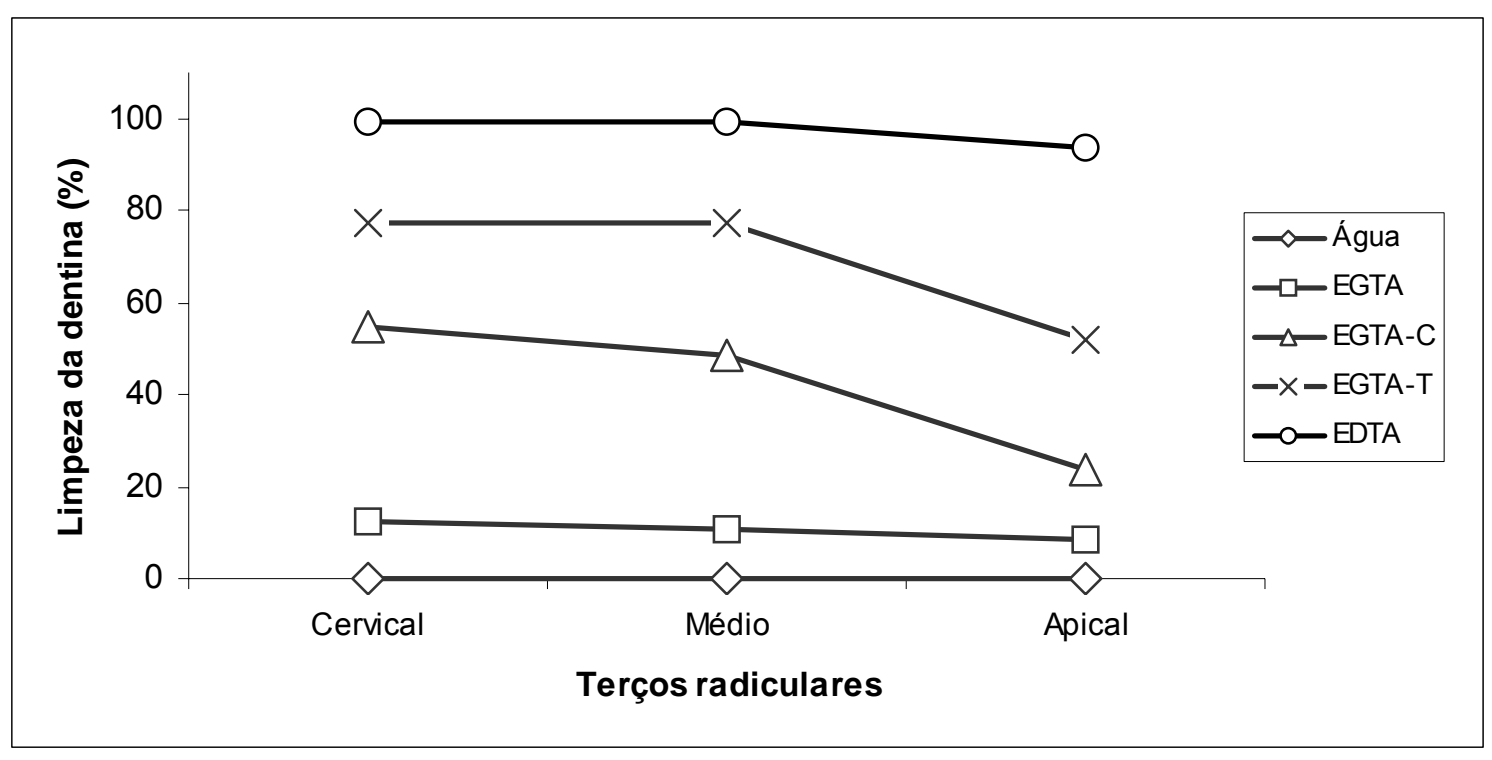

Figura 9 - Gráfico dos valores médios da porcentagem de limpeza proporcionada pelas soluções irrigadoras testadas, em cada terço radicular examinado. 


\section{2 - PERMEABILIDADE DENTINÁRIA}

Os resultados obtidos neste teste podem ser vistos na tabela 11 .

Imagens representativas dos terços cervical, médio e apical dos dentes dos cinco grupos experimentais podem ser vistas na figura 10 .

Tabela 11 - Porcentagem de penetração dos íons cobre na dentina, resultado da reação com o ácido rubeânico, em função de cada solução irrigadora utilizada e cada terço radicular examinado - Média e desvio padrão.

\begin{tabular}{|c|c|c|c|c|c|}
\hline \multirow{2}{*}{ TERÇOS } & \multicolumn{5}{|c|}{ SOLUÇÕES IRRIGADORAS } \\
\hline & Água destilada & EGTA & EGTA-C & EGTA-T & EDTA \\
\hline \multirow{6}{*}{ Cervical } & 3,36 & 10,63 & 11,28 & 12,45 & 16,58 \\
\hline & 2,82 & 10,39 & 11,02 & 12,37 & 14,04 \\
\hline & 5,17 & 9,85 & 10,69 & 11,89 & 14,35 \\
\hline & 1,04 & 10,61 & 10,98 & 12,68 & 16,85 \\
\hline & 3,85 & 9,62 & 11,01 & 12,49 & 12,82 \\
\hline & $X=3,24 \pm 1,51$ & $X=10,22 \pm 0,46$ & $X=11,00 \pm 0,20$ & $X=12,38 \pm 0,29$ & $X=14,93 \pm 1,73$ \\
\hline \multirow{6}{*}{ Médio } & 3,17 & 7,11 & 7,87 & 8,95 & 14,68 \\
\hline & 2,01 & 5,99 & 7,38 & 8,33 & 9,11 \\
\hline & 3,57 & 5,86 & 6,20 & 8,90 & 9,98 \\
\hline & 1,38 & 6,44 & 6,70 & 7,94 & 14,68 \\
\hline & 1,00 & 5,91 & 7,22 & 8,98 & 9,71 \\
\hline & $X=2,22 \pm 1,11$ & $x=6,26 \pm 0,52$ & $X=7,07 \pm 0,64$ & $X=8,62 \pm 0,46$ & $x=11,63 \pm 2,80$ \\
\hline \multirow{6}{*}{ Apical } & 1,44 & 2,47 & 4,36 & 6,60 & 12,56 \\
\hline & 1,30 & 1,78 & 4,05 & 5,45 & 7,02 \\
\hline & 1,45 & 1,70 & 2,63 & 5,95 & 8,98 \\
\hline & 1,16 & 2,42 & 2,67 & 4,45 & 11,63 \\
\hline & 1,40 & 1,77 & 2,73 & 5,27 & 7,91 \\
\hline & $X=1,35 \pm 0,12$ & $X=2,02 \pm 0,38$ & $X=3,28 \pm 0,84$ & $X=5,54 \pm 0,80$ & $X=9,62 \pm 2,38$ \\
\hline
\end{tabular}



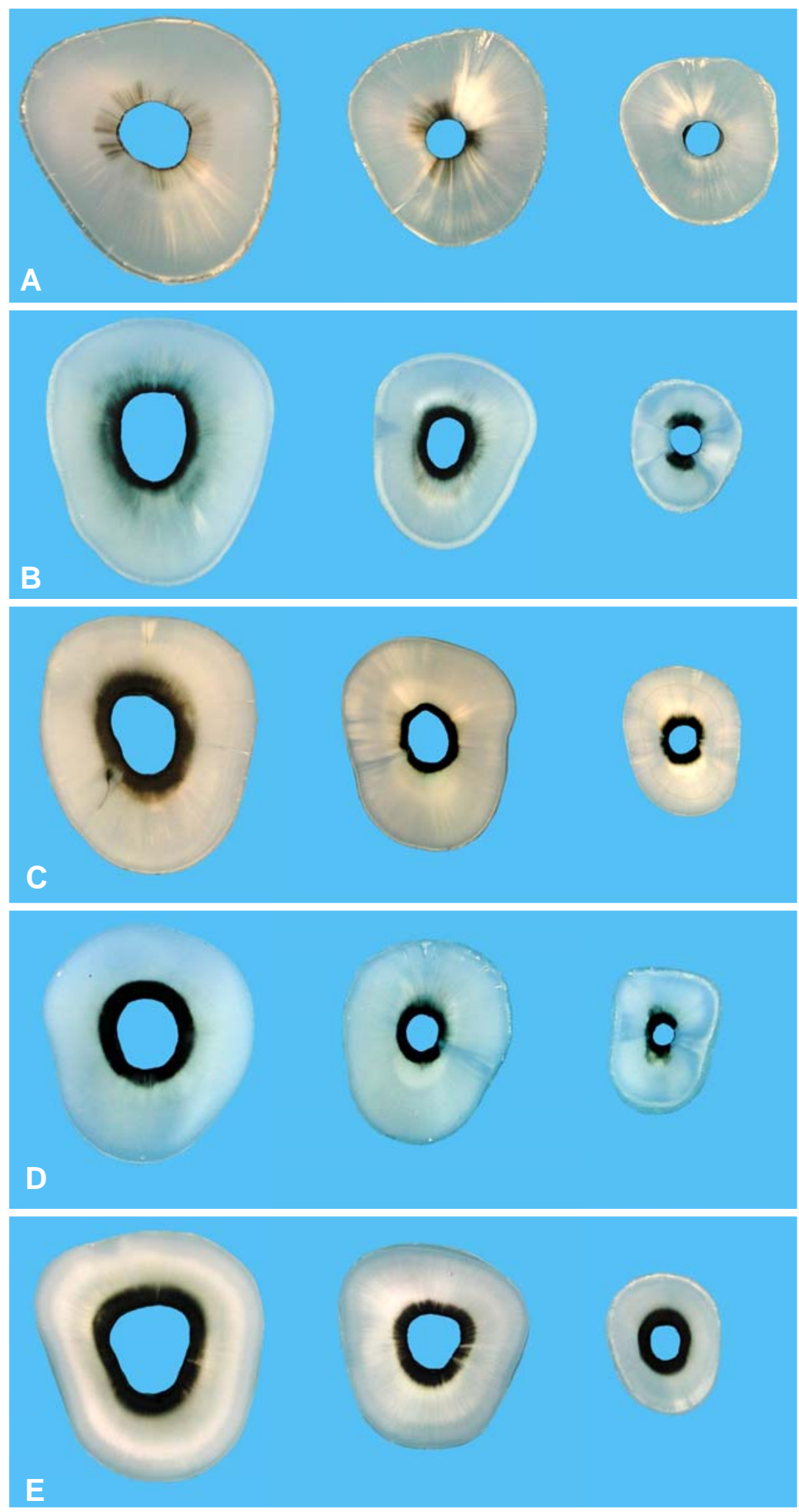

Figura 10 - Imagens representativas dos fragmentos obtidos dos terços cervical, médio e apical, respectivamente, da esquerda para a direita, dos cinco grupos experimentais: Água (A), EGTA (B), EGTA-C (C), EGTA-T (D) e EDTA (E). 
Assim como no experimento anterior, estes valores consistiram do produto fatorial de cinco soluções irrigadoras testadas (água destilada, EGTA, EGTA-C, EGTA-T e EDTA), três terços radiculares (cervical, médio e apical) e cinco repetições, totalizando 75 valores numéricos.

De posse dos valores da porcentagem de penetração dos íons cobre na dentina, evidenciados pela reação com o ácido rubeânico, realizou-se o teste estatístico preliminar de Bartlett, que verifica se as variâncias são homocedásticas, ou seja, se as variâncias são estatisticamente semelhantes ou não. Os resultados do teste de Bartlett para os fatores de variação "Soluções irrigadoras" e "Terços radiculares" podem ser vistos na tabela 12 .

Tabela 12 - Resultado do teste estatístico de Bartlett.

\begin{tabular}{lcc}
\hline Fatores de Variação & $\begin{array}{c}\text { Soluções } \\
\text { irrigadoras }\end{array}$ & $\begin{array}{c}\text { Terços } \\
\text { radiculares }\end{array}$ \\
\hline Valor estatístico de Bartlett & 12,9 & 1,487 \\
Valor de P & 0,0117 & 0,4756 \\
Valor de P (Resumo) & $*$ & ns \\
As variâncias diferem significativamente $(p<0,05)$ & Sim & Não \\
\hline
\end{tabular}

ns = não significante

* = significante ao nível de $5 \%$

O teste de Bartlet evidenciou haver diferença entre as variâncias $(P<0,05)$, contra-indicando a realização de testes estatísticos paramétricos para o fator de variação "Soluções irrigadoras". Desta forma, realizou-se a transformação dos dados amostrais, por meio da raiz quadrada dos valores originais (Tabela 13). 
Tabela 13 - Dados originais transformados (raiz quadrada).

\begin{tabular}{lccccc}
\hline \multirow{2}{*}{ TERÇOS } & \multicolumn{5}{c}{ SOLUÇÕES IRRIGADORAS } \\
\cline { 2 - 6 } & Água destilada & EGTA & EGTA-C & EGTA-T & EDTA \\
\hline \multirow{6}{*}{ Cervical } & 1,83 & 3,26 & 3,35 & 3,52 & 4,07 \\
& 1,67 & 3,22 & 3,32 & 3,51 & 3,74 \\
& 2,27 & 3,13 & 3,27 & 3,44 & 3,78 \\
& 1,02 & 3,25 & 3,31 & 3,56 & 4,10 \\
Médio & 1,96 & 3,10 & 3,31 & 3,53 & 3,58 \\
& 1,78 & 2,66 & 2,80 & 2,99 & 3,83 \\
& 1,41 & 2,44 & 2,71 & 2,88 & 3,01 \\
& 1,88 & 2,42 & 2,49 & 2,98 & 3,15 \\
\hline \multirow{6}{*}{ Apical } & 1,17 & 2,53 & 2,58 & 2,81 & 3,83 \\
& 1,00 & 2,43 & 2,68 & 2,99 & 3,11 \\
& 1,20 & 1,57 & 2,08 & 2,56 & 3,54 \\
& 1,14 & 1,33 & 2,01 & 2,33 & 2,65 \\
& 1,20 & 1,30 & 1,62 & 2,43 & 2,99 \\
\hline
\end{tabular}

Os dados transformados foram, então, submetidos novamente ao teste estatístico preliminar de Bartlet com a finalidade de verificar se, após a transformação, as variâncias apresentavam-se homocedásticas (Tabela 14).

Tabela 14 - Resultado do teste estatístico de Bartlett - Fator de Variação "Soluções Irrigadoras" (Dados transformados).

\begin{tabular}{lc}
\hline Fatores de Variação & Soluções irrigadoras \\
\hline Valor estatístico de Bartlett & 7,340 \\
Valor de P & 0,1190 \\
Valor de P (Resumo) & ns \\
As variâncias diferem significativamente $(p<0,05)$ & Não
\end{tabular}

ns = não significante 
Após a transformação dos dados amostrais, o teste de Bartlett evidenciou não haver diferença significante entre as variâncias testadas ( $p>0,05)$, permitindo, assim, a utilização de testes estatísticos paramétricos para o fator de variação "Soluções Irrigadoras". O teste paramétrico que melhor se adapta ao modelo experimental é a análise de variância para dados múltiplos e independentes (One-Way ANOVA). Os resultados deste teste estão dispostos nas Tabelas 15 e 16.

Tabela 15 - Resultado da análise de variância: Fator de variação "Soluções Irrigadoras".

Fator de Variação

Número de grupos

Valor de F

Valor de $\mathrm{R}^{2}$

Valor de $\mathrm{P}$

Valor de $\mathrm{P}$ (resumo)

As médias diferem significativamente $(p<0,05)$
Soluções Irrigadoras 5 24,79

0,5862

$P<0,0001$

Sim

***: significante ao nível de $0,1 \%$

Tabela 16 - Resultado da análise de variância: Fator de variação "Soluções Irrigadoras".

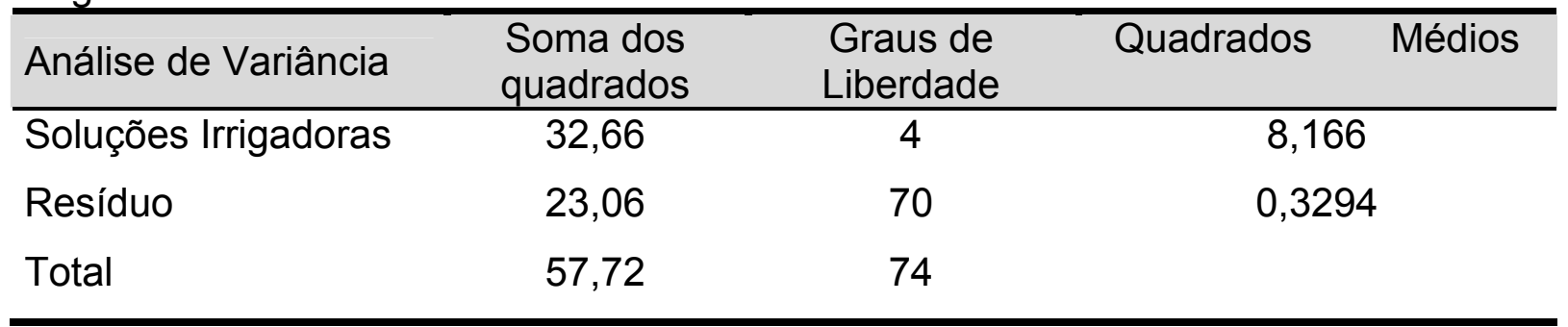

Uma vez que a análise de variância demonstrou haver diferença estatisticamente significante $(p<0,0001)$, para identificar quais dentre as soluções irrigadoras testadas eram estatisticamente diferentes entre si, realizou-se o teste complementar de Tukey (Tabela 17). 
Tabela 17 - Resultado do Teste de Tukey: Entre as soluções irrigadoras estudadas.

\begin{tabular}{lcccc}
\hline \multicolumn{1}{c}{ Teste de Tukey } & $\begin{array}{c}\text { Diferença entre } \\
\text { as Médias }\end{array}$ & $\mathrm{q}$ & Valor de $\mathrm{P}$ & Resumo \\
\hline Água vs EGTA & 0,9163 & 6,184 & $\mathrm{P}<0.001$ & $* * *$ \\
Água vs EGTA-C & 1,1360 & 7,666 & $\mathrm{P}<0.001$ & $* * *$ \\
Água vs EGTA-T & 1,4785 & 9,977 & $\mathrm{P}<0.001$ & $* * *$ \\
Água vs EDTA & 1,9884 & 13,42 & $\mathrm{P}<0.001$ & $* * *$ \\
EGTA vs EGTA-C & 0,2197 & 1,482 & $\mathrm{P}>0.05$ & $\mathrm{~ns}$ \\
EGTA vs EGTA-T & 0,5621 & 3,793 & $\mathrm{P}>0.05$ & $\mathrm{~ns}$ \\
EGTA vs EDTA & 1,0721 & 7,235 & $\mathrm{P}<0.001$ & $* * *$ \\
EGTA-C vs EGTA-T & 0,3425 & 2,311 & $\mathrm{P}>0.05$ & $\mathrm{~ns}$ \\
EGTA-C vs EDTA & 0,8524 & 5,752 & $\mathrm{P}<0.01$ & $* *$ \\
EGTA-T vs EDTA & 0,5100 & 3,441 & $\mathrm{P}>0.05$ & $\mathrm{~ns}$ \\
\hline
\end{tabular}

ns: não significante

**: significante ao nível de $1 \%$

***: significante ao nível de $0,1 \%$

O teste complementar de Tukey evidenciou haver diferença estatisticamente significante entre o grupo da água destilada (controle negativo) e os grupos experimentais tratados com as soluções de EGTA, EGTA-C, EGTA-T e EDTA (controle positivo), sendo que a água destilada, foi estatisticamente inferior às outras soluções experimentais, quanto à capacidade de aumentar a permeabilidade dentinária $(p<0,01)$.

As soluções de EGTA, EGTA-C e EGTA-T apresentaram resultados estatisticamente semelhantes entre sí $(p>0,05)$. Dentre estas, a solução de EGTA-T foi a única solução a obter resultados estatisticamente semelhantes aos obtidos com o uso da solução de EDTA ( $p>0,05)$, que por sua vez apresentou os melhores resultados quanto à capacidade de aumentar a permeabilidade da dentina das paredes dos canais radiculares instrumentados (Figura 11). 


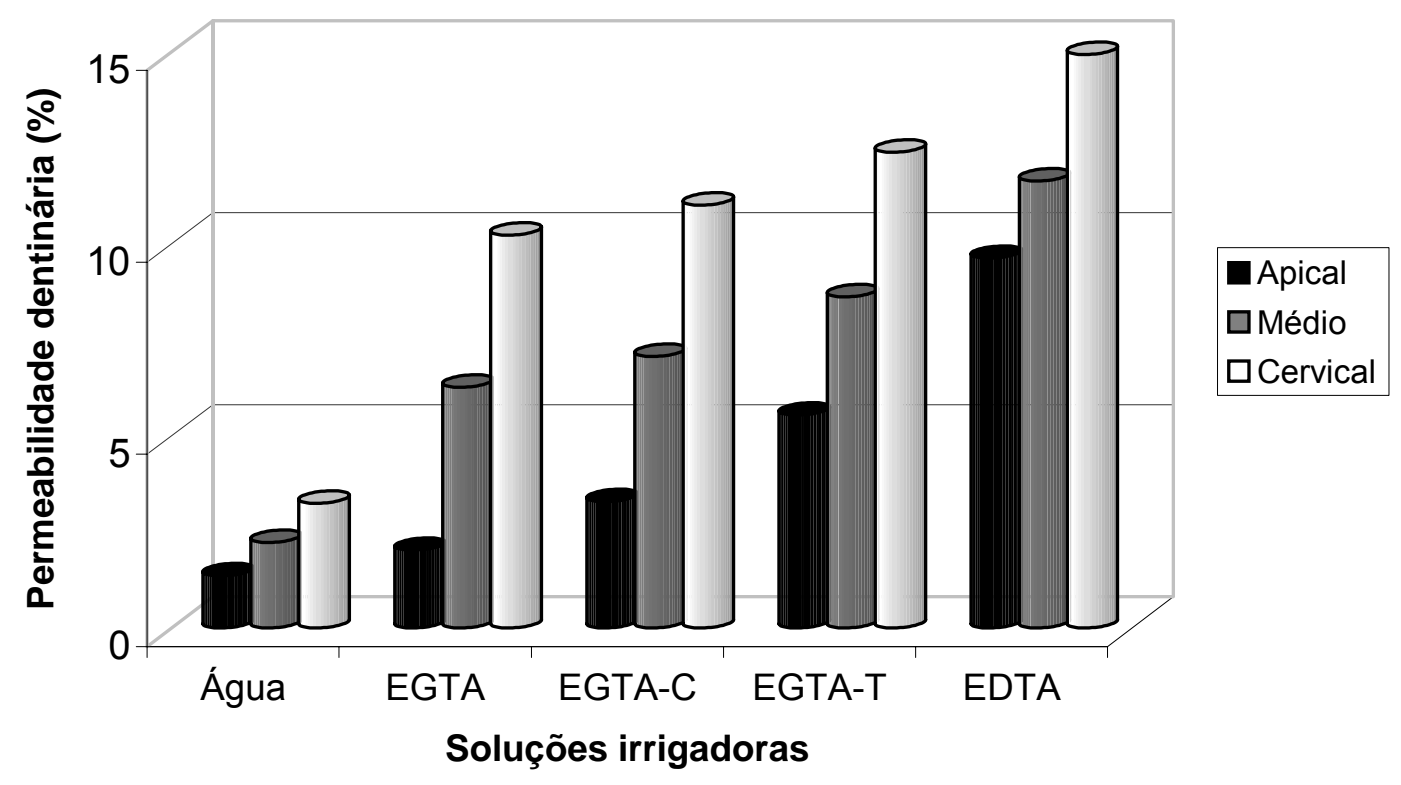

Figura 11 - Gráfico dos valores médios da permeabilidade dentinária em função de cada solução irrigadora testada e terço radicular examinado.

Em relação à análise do fator de variação "Terços Radiculares", o teste de Bartlett evidenciou haver semelhança estatística entre as variâncias testadas $(p>0,05)$, o que permitiu a utilização de testes estatísticos paramétricos. O teste paramétrico que melhor se adapta ao modelo experimental é a análise de variância para dados múltiplos e vinculados (Repeated Measures ANOVA). Os resultados da análise de variância para o fator de variação "Terços Radiculares", estão dispostos nas tabelas 18 e 19.

Tabela 18 - Resultado da análise de variância: Fator de variação "Terços Radiculares".

\begin{tabular}{lc}
\hline Fator de Variação & Terços Radiculares \\
\hline Número de grupos & 3 \\
Valor de F & 134,4 \\
Valor de $\mathrm{R}^{2}$ & 0,8485 \\
Valor de P & $\mathrm{P}<0,0001$ \\
Valor de P (resumo) & $* * *$ \\
As médias diferem significativamente $(\mathrm{p}<0,05)$ & $\mathrm{Sim}$ \\
\hline
\end{tabular}


Tabela 19 - Resultado da análise de variância: Fator de variação "Terços Radiculares".

\begin{tabular}{|c|c|c|c|c|}
\hline Análise de Variância & $\begin{array}{l}\text { Soma dos } \\
\text { quadrados }\end{array}$ & $\begin{array}{l}\text { Graus de } \\
\text { Liberdade }\end{array}$ & Quadrados & Médios \\
\hline Terços & 448,8 & 2 & 224,4 & \\
\hline Individual & 850,8 & 24 & 35,45 & \\
\hline Resíduo & 80,16 & 48 & 1,670 & \\
\hline Total & 1380 & 74 & & \\
\hline
\end{tabular}

Uma vez que a análise de variância demonstrou haver diferença estatisticamente significante $(p<0,0001)$, para identificar quais dentre os terços radiculares eram estatisticamente diferentes entre si, realizou-se o teste complementar de Tukey, entre as médias dos terços estudados (Tabela 20).

Tabela 20 - Resultados do teste de Tukey: Fator de variação "Terços radiculares".

\begin{tabular}{lcccc}
\hline \multicolumn{1}{c}{ Teste de Tukey } & $\begin{array}{c}\text { Diferença entre } \\
\text { as Médias }\end{array}$ & $\mathrm{q}$ & Valor de $\mathrm{P}$ & Resumo \\
\hline Cervical vs Médio & 3,191 & 12,35 & $\mathrm{p}<0,001$ & $* * *$ \\
Cervical vs Apical & 5,988 & 23,17 & $\mathrm{p}<0,001$ & $* * *$ \\
Médio vs Apical & 2,797 & 10,82 & $\mathrm{p}<0,001$ & $* * *$
\end{tabular}

***: significante ao nível de $0,1 \%$

O teste complementar de Tukey, de modo geral, mostrou haver diferença estatística siginificante entre os três terços radiculares examinados $(p<0,001)$.

Dentre estes, o terço cervical apresentou os maiores valores de permeabilidade dentinária, seguido do terço médio com valores intermediários. Já o terço apical, apresentou os menores valores de permeabilidade observados.

Contudo, numa análise individual, as soluções irrigadoras apresentaram resultados distintos, que podem ser vistos na Figura 12 e na Tabela 21. 


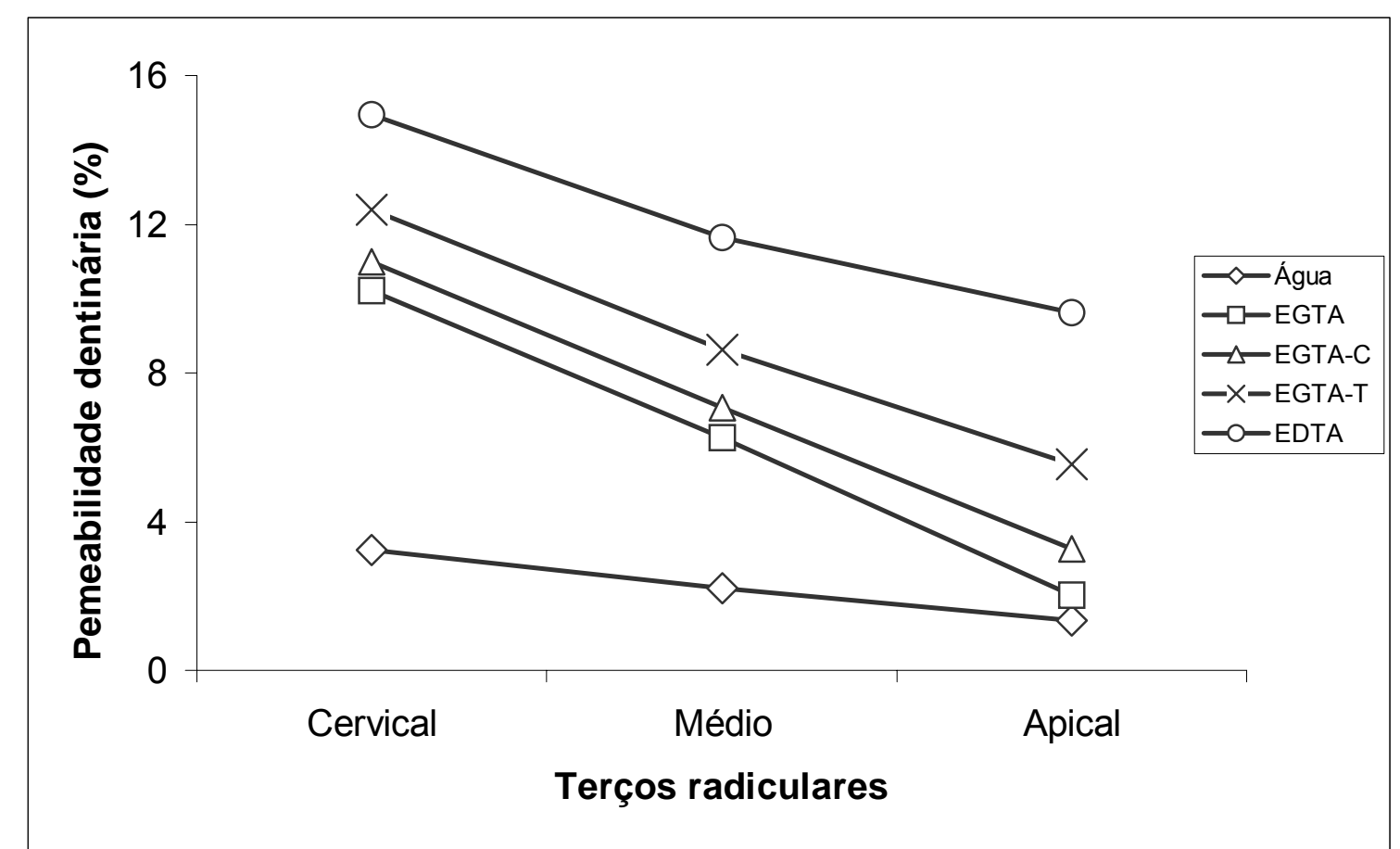

Figura 12 - Gráfico dos valores médios da permeabilidade dentinária proporcionada pelas soluções irrigadoras testadas em cada terço radicular examinado. 
Tabela 21 - Teste de Tukey: análise do comportamento individual de cada solução nos diversos terços radiculares estudados.

\begin{tabular}{|c|c|c|c|c|c|}
\hline $\begin{array}{l}\text { Soluções } \\
\text { Irrigadoras }\end{array}$ & $\begin{array}{l}\text { Teste comparações } \\
\text { Múltiplas de Tukey }\end{array}$ & $\begin{array}{l}\text { Diferença entre } \\
\text { as médias }\end{array}$ & q & Valor de P & Resumo \\
\hline \multirow{3}{*}{$\begin{array}{c}\text { Água } \\
\text { Destilada }\end{array}$} & Cervical vs Médio & 1,022 & 2,105 & $P>0.05$ & ns \\
\hline & Cervical vs Apical & 1,898 & 3,908 & $P<0.05$ & * \\
\hline & Médio vs Apical & 0,876 & 1,804 & $P>0.05$ & ns \\
\hline \multirow{3}{*}{ EGTA } & Cervical vs Médio & 3,958 & 19,23 & $P<0.001$ & *** \\
\hline & Cervical vs Apical & 8,192 & 39,81 & $P<0.001$ & *** \\
\hline & Médio vs Apical & 4,234 & 20,57 & $P<0.001$ & *** \\
\hline \multirow{3}{*}{ EGTA-C } & Cervical vs Médio & 3,922 & 14,04 & $P<0.001$ & *** \\
\hline & Cervical vs Apical & 7,708 & 27,59 & $P<0.001$ & *** \\
\hline & Médio vs Apical & 3,786 & 13,55 & $P<0.001$ & $* * *$ \\
\hline \multirow{3}{*}{ EGTA-T } & Cervical vs Médio & 3,756 & 14,98 & $P<0.001$ & *** \\
\hline & Cervical vs Apical & 6,832 & 27,25 & $P<0.001$ & *** \\
\hline & Médio vs Apical & 3,076 & 12,27 & $P<0.001$ & *** \\
\hline \multirow{3}{*}{ EDTA } & Cervical vs Médio & 3,296 & 3,139 & $P>0.05$ & ns \\
\hline & Cervical vs Apical & 5,308 & 5,056 & $P<0.01$ & ** \\
\hline & Médio vs Apical & 2,012 & 1,916 & $P>0.05$ & ns \\
\hline
\end{tabular}

ns: não significante

*: significante ao nível de $5 \%$

**: significante ao nível de $1 \%$

${ }^{* * *}$ : significante ao nível de $0,1 \%$

Para verificar se haveria alguma relação entre os resultados obtidos nos dois testes realizados, aplicou-se o teste estatístico de correlação de Spearman. Para a realização deste teste, foram utilizados os valores médios obtidos por cada solução irrigadora testada, em cada terço radicular e em cada experimento realizado (Tabela 22). 
Tabela 22 - Valores médios obtidos em função da solução irrigadora testada, do terço radicular avaliado e do teste realizado.

\begin{tabular}{|c|c|c|c|}
\hline \multirow{2}{*}{$\begin{array}{l}\text { Soluções } \\
\text { Irrigadoras }\end{array}$} & \multirow{2}{*}{$\begin{array}{c}\text { Terços } \\
\text { Radiculares }\end{array}$} & \multicolumn{2}{|c|}{ Resultados (Valores médios) } \\
\hline & & Limpeza dentinária & Permeabilidade dentinária \\
\hline \multirow{3}{*}{ Água Destilada } & Cervical & 0,20 & 3,24 \\
\hline & Médio & 0,06 & 2,22 \\
\hline & Apical & 0,00 & 1,35 \\
\hline \multirow{3}{*}{ EGTA } & Cervical & 12,56 & 10,22 \\
\hline & Médio & 10,90 & 6,26 \\
\hline & Apical & 8,60 & 2,02 \\
\hline \multirow{3}{*}{ EGTA-C } & Cervical & 54,58 & 11,00 \\
\hline & Médio & 48,68 & 7,07 \\
\hline & Apical & 23,95 & 3,28 \\
\hline \multirow{3}{*}{ EGTA-T } & Cervical & 77,56 & 12,38 \\
\hline & Médio & 77,08 & 8,62 \\
\hline & Apical & 51,80 & 5,54 \\
\hline \multirow{3}{*}{ EDTA } & Cervical & 99,23 & 14,93 \\
\hline & Médio & 99,16 & 11,63 \\
\hline & Apical & 93,88 & 9,62 \\
\hline
\end{tabular}

Os resultados do teste de Spearman podem ser vistos na Tabela 23.

Tabela 23 - Resultados do teste de correlação de Spearman entre os valores médios obtidos pela análise da limpeza da superfície dentinária e pela análise da permeabilidade da dentina.

\begin{tabular}{lc}
\hline Teste de Correlação de Spearman & Limpeza vs Permeabilidade \\
\hline Número de pares & 15 \\
Valor estatístico de Spearman $(r)$ & 0,8750 \\
Intervalo de confiança (95\%) & 0,6477 a 0,9593 \\
Valor de P & $p<0,0001$ \\
Valor de P (resumo) & $* * *$ \\
Valor de P exato ou aproximado? & Aproximação Gaussiana \\
Há correlação significante $(p=0,05)$ & Sim
\end{tabular}

*** = Significante ao nível de 0,1\% 
O teste de Spearman evidenciou haver correlação entre os resultados obtidos nos dois experimentos realizados ( $p<0,0001$ ), ou seja, quanto maior a capacidade de limpeza da solução irrigadora testada, maior a capacidade desta aumentar a permeabilidade da dentina. Isto pode ser visto mais claramente na Figura 13.

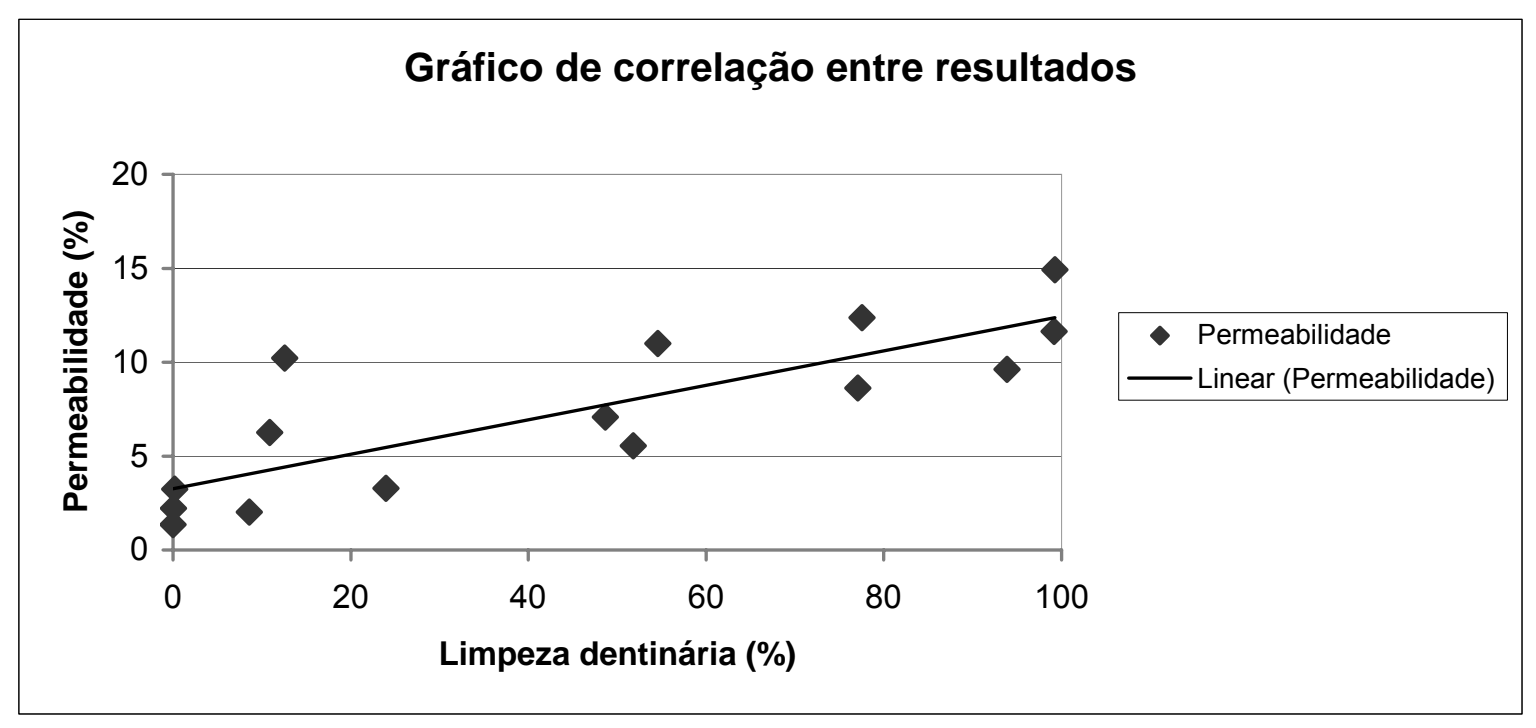

Figura 13 - Gráfico da correlação entre os resultados obtidos pela análise da limpeza da superfície dentinária e pela análise da permeabilidade dentinária. 
6 - DISCUSSÃO 


\section{6 - DISCUSSÃO}

As patologias pulpares e periapicais são, freqüentemente, de origem infecciosa e o tratamento endodôntico, nesses casos, tem como principal finalidade, controlar a infecção presente no sistema de canais radiculares dando condições para que ocorra o processo de reparação, devolvendo, assim, a funcionalidade ao elemento envolvido.

Para promover a sanificação do sistema de canais radiculares, é necessário o emprego concomitante de instrumentos e substâncias químicas auxiliares específicas.

Entretanto, sabe-se que a ação mecânica dos instrumentos nas paredes dentinárias resulta na formação de uma camada de resíduos fracamente aderida à superfície da dentina, chamada de smear layer. Esta apresenta efeitos deletérios para o tratamento endodôntico, prejudicando a ação de soluções irrigadoras e substâncias medicamentosas que têm, entre outras finalidades, a de auxiliar na promoção da desinfecção do sistema de canais radiculares (SEN; WESSELINK; TÜRKÜN $\left.{ }^{152}, 1995\right)$.

Além disso, age como uma barreira física, dificultando a penetração dos cimentos endodônticos nos túbulos dentinários, prejudicando a adesão dos cimentos às paredes do canal radicular e afetando a eficiência de selamento da obturação (WHITE; GOLDMAN; LIN ${ }^{185}, 1984$, WHITE; GOLDMAN; LIN ${ }^{186}, 1987$ ).

Apesar de não ser uma decisão unânime (DRAKE et al. ${ }^{48}$, 1994, PEREZ; CALAS; ROCHD ${ }^{128}$, 1996, MOSS; ALLEMANG; JOHNSON ${ }^{106}$, 2001, TIMPAWAT; VONGSAVAN; MESSER ${ }^{175}$, 2001, TORABINEJAD et al. $^{176}$, 2002), a remoção da smear layer têm sido preconizada por inúmeros autores, com a finalidade de tornar os túbulos dentinários patentes ou desobstruídos.

Dentre os métodos empregados na remoção da smear layer, o uso da solução quelante de EDTA é, provavelmente o mais preconizado, quer seja durante a instrumentação dos canais, quer seja após o término do preparo. Também têm sido utilizadas soluções ácidas como o ácido cítrico em diversas concentrações, ácido lático, derivados da tetraciclina, como a doxiciclina e, inclusive, o laser. 
Recentemente, a solução de EGTA [ácido etilenoglicol bis ( $\beta$-amino-etil-eter)$\mathrm{N}, \mathrm{N}, \mathrm{N}$ ',N'-tetracético] foi introduzida na endodontia. Inicialmente, com a finalidade de promover a redução da microdureza da dentina, facilitando, assim a instrumentação de canais atrésicos e calcificados (CRUZ-FILHO ${ }^{38}$, 1998). Pouco tempo depois, sua utilização na remoção da smear layer começou a ser estudada (ÇALT; SERPER ${ }^{24}$, 2000, VISWANATH; HEGDE; MUNSHI ${ }^{179}$, 2003). Entre suas características, destaca-se o fato desta solução ter uma maior especificidade para quelar íons cálcio (SCHMID; REILLEY ${ }^{151}, 1957$ ).

Em teoria, sendo específico para íons cálcio, o EGTA poderia ser associado a outras substâncias, como agentes antimicrobianos e/ou tensoativos, provavelmente, sem que seu efeito quelante pudesse interferir ou ser prejudicado, como resultado de reação química entre as substâncias associadas.

GUIMARÃES et al. $^{74}$, em 1988, sugeriram a adição de tensotivos à composição das soluções irrigadoras aquosas, para uma maior eficiência e uma rápida atuação. Os autores avaliaram a tensão superficial de várias soluções auxiliares da instrumentação dos canais radiculares, pelo método de ascensão capilar, e observaram que a adição de tensoativos à solução quelante de EDTA reduzia sensivelmente sua tensão superficial. A solução de EDTA proposta originalmente por $\varnothing S T B Y^{115}$, em 1957, apresentava tensão superficial de 69,25 dinas/cm e a adicão de $0,1 \%$ de Cetavlon (tensoativo catiônico) fez com que esta tensão superficial caísse para 33,92 dinas/cm. O Lauril sulfato de sódio a $0,1 \%$ (tensoativo aniônico) apresentou a menor tensão superficial dentre as soluções estudadas.

Contudo, não existem trabalhos na literatura analisando os efeitos da adição de tensoativos à solução de EGTA. Por este motivo, em uma primeira etapa desta pesquisa, foi avaliada a capacidade de limpeza da superfície dentinária da solução de EGTA isolada ou associada a um tensoativo catiônico ou aniônico.

Para este experimento foram utilizados incisivos centrais superiores, por serem dentes que apresentam poucas interferências anatômicas que poderiam influenciar os resultados. Raízes achatadas, curvas e/ou com canais atrésicos, poderiam funcionar como variáveis adicionais indesejáveis. As raízes, sendo relativamente retas e cilíndricas, sem achatamento nas superfícies proximais, 
favoreceram, também, a clivagem para obtenção das amostras a serem analisadas em microscopio eletrônico de varredura.

A determinação do número de dentes em cada grupo experimental foi

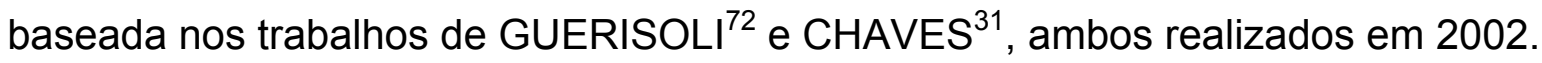

Foram empregadas cânulas de calibre 25X4, para irrigação dos canais radiculares, com base no trabalho de KAHN; ROSENBERG; GLIKSBERG ${ }^{84}$, 1995. Estes autores avaliaram, em canais radiculares artificiais, a efetividade da irrigação obtida por meio de diversos tipos de cânulas e concluíram que a cânula 27 (25X4) foi altamente efetiva na remoção da tinta dos canais, quando instrumentados com limas tipo K, de numeração 30 ou superior. Os autores verificaram, ainda, que a limpeza tornava-se melhor quando a cânula era posicionada a uma distância de 1 a $2 \mathrm{~mm}$ do término do canal.

Adotou-se, portanto, a técnica step-back para a instrumentação dos canais radiculares, visando ampliar mais acentuadamente os terços médio e cervical, com o intuito de contribuir na limpeza do terço apical, favorecendo, assim, a penetração da agulha e da solução irrigadora, conforme as observações de BOLANOS; JENSEN ${ }^{18}$, 1980, e de SCELZA ${ }^{145}, 1998$.

Com a finalidade de eliminar possíveis variáveis, padronizou-se o número de instrumentos para o preparo dos canais radiculares, tomando-se o cuidado de selecionar o instrumento inicial, com base no diâmetro anatômico de cada canal a ser instrumentado. Foram empregados três instrumentos de numeração crescente, a partir do instrumento inicial, para a realização do preparo apical e outros quatro para a realização do escalonamento com recuo programado $(1 \mathrm{~mm})$, e recapitulação com a lima de memória no comprimento real de trabalho (CRT).

Com base no trabalho de AUN; PAIVA; ANTONIAZZI ${ }^{9}$, de 1990, para evitar que a perda de corte dos instrumentos pudesse influenciar os resultados, estes foram substituídos após cinco utilizações.

A solução de hipoclorito de sódio a $2 \%$ foi escolhida para ser utilizada durante o preparo dos canais devido à sua capacidade de dissolução de matéria orgânica. Havia a necessidade de eliminação do conteúdo orgânico que pudesse estar depositado nas paredes dos canais radiculares, previamente à aplicação das soluções a serem testadas, uma vez que tanto as soluções experimentais de EGTA, 
quanto a solução de EDTA (controle positivo) e a água destilada (controle negativo), são desprovidas de capacidade de dissolução de matéria orgânica. Portanto, a manutenção de resíduos pulpares poderia dificultar ou até mesmo impedir a correta avaliação da superfície dentinária e, por conseqüencia, a análise da capacidade de limpeza das soluções quelantes.

A metodologia utilizada para avaliação da capacidade de limpeza das paredes dos canais radiculares foi a microscopia eletrônica de varredura (MEV), meio pelo qual foi mensurada a capacidade de remoção de smear layer da superfície dentinária.

A microscopia eletrônica de varredura vem sendo utilizada e considerada um método apropriado para avaliação da capacidade de limpeza da dentina, desde meados da década de 70 (McCOMB; SMITH ${ }^{101}$, 1975, McCOMB; SMITH; BEAGRIE ${ }^{102}$, 1976, MOODNIK et al. ${ }^{103}$, 1976, GOLDBERG; ABRAMOVICH ${ }^{66}, 1977$, BOLANOS; JENSEN ${ }^{18}, 1980$, GOLDBERG; SPIELBERG ${ }^{67}$, 1982, YAMADA et al. ${ }^{188}$, 1983, BRANCINI; BRAMANTE; BERBERT ${ }^{19}$, 1983, BAUMGARTNER et al. ${ }^{13}, 1984$, MADER; BAUMGARTNER; PETERS ${ }^{96}$, 1984, AUN ${ }^{7}, 1985$, PROKOPOWITSCH $^{133}$, 1988, CIUCCHI; KHETTABI; HOLZ ${ }^{33}$, 1989, AUN ${ }^{8}, 1990$, GAVINI $^{63}, 1992$, GAVINI $^{64}$, 1994, PROKOPOWITSCH ${ }^{134}$, 1994, SCELZA ${ }^{145}$, 1998, GAMBARINI ${ }^{60}, 1999$, PETERS; BARBAKOW ${ }^{131}$, 2000, SCHÄFER; ZAPKE ${ }^{149}$, 2000, MAYER; PETERS; BARBAKOW $^{100}, 2002$, AHLQUIST et al. $\left.{ }^{2}, 2002\right)$.

Apesar de grande parte dos trabalhos encontrados na literatura utilizarem escores para estabelecer o grau de limpeza, optou-se, nesta pesquisa, por uma análise por meio da porcentagem de limpeza da parede dentinária dos canais radiculares.

Quando são utilizados escores, há uma perda de precisão dos resultados, uma vez que, neste caso, diferentes imagens são agrupadas em uma mesma categoria como, por exemplo: superfície dentinária totalmente limpa, parcialmente limpa ou suja (DI LENARDA; CADENARO; SBAIZERO ${ }^{44}$, 2000).

Outro fator desfavorável é a necessidade da utilização de, pelo menos, três examinadores, que precisam ser previamente calibrados, para haver uma uniformidade no processo de avaliação. Para dissipar eventuais discrepâncias neste 
processo, é necessário aumentar o número de amostras em cada grupo experimental (SCELZA $\left.{ }^{145}, 1998\right)$.

Neste trabalho, para tentar minimizar este problema, foi confeccionada, digitalmente, uma grade quadriculada padronizada, contendo 288 quadrantes, que foi sobreposta às fotomicrografias digitais obtidas por meio da microscopia eletrônica. A contagem do número de quadrantes limpos nas fotomicrografias possibilitou o estabelecimento da porcentagem de limpeza da superfície dentinária. Com isso foi possível estabelecer valores individuais para cada terço radicular, de cada raiz analisada, em cada grupo experimental.

Morfologicamente, a dentina radicular apresenta características distintas, sendo que, no terço apical, ela é parcialmente atubular e esclerótica, com tubulos dentinários em menor número e diâmetro, quando comparada com a dentina dos terços cervical e médio.

GARBEROGLIO; BRÄMSTRÖM ${ }^{62}$, em 1976, e FOGEL; MARSHALL; PASHLEY ${ }^{53}$, em 1988, verificaram que a densidade de túbulos dentinários diminui de, aproximadamente, 42.000 túbulos por milímetro quadrado na dentina cervical, para 8.000 túbulos por milímetro quadrado na dentina radicular apical.

Por este motivo, a avaliação da limpeza dentinária foi realizada em cada terço radicular (cervical, médio e apical) ao contrário de alguns trabalhos disponíveis na literatura, que consideraram a análise somente do terço apical (AUN ${ }^{7}, 1985, \mathrm{AUN}^{8}$, 1990, GAVINI ${ }^{63}, 1992$, GAVINI $\left.^{64}, 1994\right)$.

Como neste trabalho havia a necessidade de uma boa visualização da abertura dos túbulos dentinários, para estabelecer a limpeza dentinária em cada quandrante analisado nas fotomicrografias, optou-se pela obtenção de imagens com um aumento de 1000x, com base nos trabalhos de MOODNIK et al. ${ }^{103}, 1976$, GOLDBERG; ABRAMOVICH ${ }^{66}$, 1977, BOLANOS; JENSEN ${ }^{18}, 1980$, GOLDBERG; SPIELBERG ${ }^{67}, 1982, \mathrm{AUN}^{7}, 1985, \mathrm{PROKOPOWITSCH}^{133}, 1988, \mathrm{AUN}^{8}, 1990$, GAVINI $^{63}, 1992$, GAVINI $^{64}, 1994$, PROKOPOWITSCH $^{134}, 1994$.

Entretanto, SCELZA ${ }^{145}$, 1998, discorda e não recomenda o emprego deste aumento, pois há uma redução da área a ser analisada. Por este motivo, a área a ser fotografada era escolhida, primeiramente, em menor aumento (100x) e, uma vez determinada a região mais representativa do terço radicular a ser fotografado, o 
microscópio eletrônico era ajustado para o aumento de 1000x e a fotomicrografia era, então, realizada.

No presente estudo, os piores resultados, em relação à capacidade de limpeza das paredes dos canais radiculares instrumentados, foram observados no terço apical, independente da solução quelante utilizada.

Estes dados estão de acordo com os encontrados por outros autores que, também, observaram uma reduzida capacidade de limpeza das soluções quelantes no terço apical dos canais radiculares, em comparação aos terços cervical e médio (BAKER et al. $^{10}, 1975, \mathrm{McCOMB}$; SMITH ${ }^{101}, 1975, \mathrm{CHOW}^{32}, 1983, \mathrm{CIUCHI}$; KHETTABI; HOLZ ${ }^{33}$, 1989, ABBOTT et al. ${ }^{1}, 1991$, AKTENER; BILKAY ${ }^{3}, 1993$, LIOLIOS et al. ${ }^{92}$, 1997, O'CONNELL et al. ${ }^{114}$, 2000, SCELZA; ANTONIAZZI; SCELZA $^{146}, 2000$, ÇALT; SERPER ${ }^{24}$, 2000, HÜSSMANN; HECKENDORFF; SCHAFERS ${ }^{82}, 2002$, LIM et al. ${ }^{91}, 2003$ ).

Devido às pequenas dimensões do canal radicular na região apical, o volume da solução em contato com as paredes é limitado, dificultando o efeito quelante da mesma.

WANDELT ${ }^{182}$, em 1965, já questionava a eficácia de soluções quelantes sobre a dentina, em porções mais estreitas dos canais, por considerar ser impossível levar uma quantidade suficiente do reagente para que o processo de quelação ocorresse de forma clinicamente satisfatória. Esta afirmação corrobora com os achados de FROMME; GUTTZEIT; RIEDEL ${ }^{58}$ que, em 1970, demonstraram uma redução da microdureza da dentina em áreas amplas do canal radicular, após o uso de uma solução quelante (EDTA), porém, não em áreas estreitas.

Outro fator que pode ter influenciado na limpeza na porção apical do canal é a dificuldade de renovação da solução no processo de irrigação e aspiração, nesta região do canal. A reduzida ação física da solução irrigadora, durante o preparo do canal, poderia resultar na manutenção de resíduos sedimentados nas paredes e na porção apical do canal radicular (ØSTBY ${ }^{116}, 1962$, HAMPSON; ATKINSON ${ }^{76}, 1964$, LOPES; SIQUEIRA; ELIAS $\left.{ }^{94}, 2004\right)$, o que dificultaria a ação da solução quelante ao final da instrumentação.

Os resultados evidenciaram, também, que a solução de EGTA, isoladamente, não foi capaz de promover uma limpeza adequada das paredes dos canais 
radiculares instrumentados, sendo estatisticamente semelhante à água destilada (controle negativo).

Estas observações divergem das obtidas por ÇALT; SERPER ${ }^{24}$, em 2000, e VISWANATH; HEGDE; MUNSHI ${ }^{179}$, em 2003. Estes autores verificaram que a solução de EGTA, sem qualquer associação com tensoativos, apresentou uma capacidade de limpeza semelhante à obtida com o uso da solução de EDTA, deixando os túbulos dentinários patentes e desobstruídos, sem, entretanto, provocar a erosão da dentina peritubular, fato observado no grupo tratado com EDTA.

A solução de EGTA, utilizada neste estudo, foi preparada a partir do ácido etileno glicol bis ( $\beta$-amino-etil-eter)-N,N,N',N'-tetracético, de procedência belga (ACROS Organics), enquanto que, ÇALT; SERPER ${ }^{24}$, em 2000, e VISWANATH; HEGDE; MUNSHI ${ }^{179}$, em 2003, utilizaram EGTA de procedência americana (SIGMAALDRICH).

A escolha do reagente para o preparo da solução de EGTA foi embasada, em um primeiro momento, no fator custo, já que ambos os reagentes, de procedência belga ou americana, apresentavam um grau de pureza semelhante, superior a 95\%, segundo informações dos fabricantes.

Uma vez que o reagente belga (ACROS Organics) apresentava um valor de importação $50 \%$ abaixo do reagente equivalente, de procedência americana (SIGMA-ALDRICH), pareceu lógico optar pelo primeiro, já que, para uma solução irrigadora ser viável, além de ser eficaz clinicamente, ela necessita ter um custo acessível. O fato de não existirem trabalhos na literatura empregando o EGTA de procedência belga, foi outro fator considerado.

O EDTA, assim como o EGTA, na forma ácida, apresenta uma baixa solubilidade em água (0,001 mol/litro) e, conseqüentemente, um pequeno poder de quelação (LOPES; SIQUEIRA; ELIAS ${ }^{94}$, 2004). Por este motivo, ØSTBY ${ }^{115}$, em 1957, preconizou o uso do EDTA na forma de sal dissódico, aumentando, assim, a solubilidade do EDTA em água $(0,4 \mathrm{~mol} / \mathrm{litro})$, permitindo o preparo de uma solução, clinicamente, mais concentrada e, portanto, mais efetiva (SOUZA et al. ${ }^{164}$, 1999).

Por ser pouco solúvel em água, o reagente orgânico EGTA de procedência belga, disponível apenas na forma ácida, utilizado neste experimento, possibilitou o preparo de uma solução aquosa na concentração de $15 \%$. Já ÇALT; SERPER ${ }^{24}$, em 
2000, e VISWANATH; HEGDE; MUNSHI ${ }^{179}$, em 2003, obtiveram uma solução aquosa de EGTA na concentração de $17 \%$.

Esta diferença de procedência do reagente e da concentração da solução utilizada pode ter influenciado negativamente os resultados da solução de EGTA, obtidos neste estudo.

Com a adição dos tensoativos, houve uma potencialização da capacidade de limpeza da solução de EGTA. A adição de tensoativos resulta em um aumento no poder de umectação da solução e, conseqüentemente, um aumento no contato desta solução com as paredes dentinárias e na sua capacidade de penetração no sistema de canais radiculares (GUIMARÃES et al. ${ }^{74}$, 1988, LEONARDO ${ }^{90}$, 1998).

$A$ adição do tensoativo catiônico (Cetavlon ${ }^{\circledR}$ ) à solução de EGTA, resultou numa melhora de sua capacidade de limpeza, porém esta melhora não foi estatisticamente significante.

Apesar de promoverem uma considerável redução da tensão superficial (GUIMARÃES et al. ${ }^{74}$, 1988), PÉCORA et al. ${ }^{126}$, em 1988 , verificaram que os tensoativos catiônicos apresentam um tempo de umectação muito longo, particularmente, o Cetavlon ${ }^{\circledR}$, quando comparado com tensoativos aniônicos.

Portanto, o tempo de contato necessário para que a solução de EGTA, acrescida de Cetavlon $^{\circledR}$, promovesse a umectação da superfície dentinária seria longo demais. Isto, provavelmente, explicaria o fato de não ter ocorrido um aumento significativo da capacidade de limpeza obtida com o EGTA-C, em relação à obtida com a solução de EGTA, isoladamente.

Já a adição do tensoativo aniônico (Tergensol ${ }^{\circledR}$ ) ao EGTA, não só resultou em uma melhora de sua capacidade de limpeza, como também, proporcionou resultados estatisticamente semelhantes aos observados com a solução de EDTA (controle positivo). Esta, por sua vez, apresentou os melhores resultados quanto à capacidade de limpeza da superfície dentinária e, conseqüentemente, quanto à remoção da smear layer.

Provavelmente, a adição do tensoativo aniônico (Tergensol ${ }^{\circledR}$ ), não só reduziu a tensão superficial da solução de EGTA, como também reduziu consideravelmente o tempo de umectação, aumentando o contato da solução com a parede dentinária, favorecendo a limpeza promovida pelo agente quelante. 
Em uma segunda etapa desta pesquisa, foi realizada a avaliação da permeabilidade dentinária, após o uso da solução de EGTA isolada ou associada a um tensoativo (catiônico ou aniônico), comparativamente à solução de EDTA (controle positivo) e à água destilada (controle negativo).

A dentina, graças a sua estrutura canalicular, é um tecido permeável e, a passagem de substâncias ou fluídos através deste tecido é referida, na literatura, como permeabilidade (SILVA et al. ${ }^{158}$, 1990).

Ao longo da evolução da pesquisa odontológica, inúmeros trabalhos foram realizados para o estudo da permeabilidade dentinária. Alguns deles utilizando corantes para sua evidenciação (ANDERSON; RONNING ${ }^{4}$, 1962, COHEN; STEWART; LASTER ${ }^{35}$, 1970, ROBAZZA ${ }^{141}$, 1973, FROIS et al. ${ }^{57}, 1981$, FELLER et al. $^{52}$, 1986, MOURA et al. $^{108}$, 1988), outros empregando radioisótopos (WAINWRIGHT; BELGOROD ${ }^{181}$, 1955, WACH; HAUPTFUEHRER; KESEL ${ }^{180}$, 1955, MARSHALL; MASSLER; DUTE ${ }^{98}$, 1960, HAMPSON; ATKINSON ${ }^{76}, 1964$, MARTIN; LASALA; MICHANOWICZ ${ }^{99}$, 1968, PASHLEY et al. ${ }^{120}$, 1981), ou, ainda, condução hidráulica (FOGEL; PASHLEY ${ }^{54}$, 1990, TAO; ANDERSON; PASHLEY ${ }^{168}, 1991$, BARBOSA; SAFAVI; SPÄNGBERG $\left.{ }^{11}, 1994\right)$.

Neste estudo, optou-se por um método histoquímico, ou seja, a utilização de uma substância indicadora revelada em um tecido (LISON $\left.{ }^{93}, 1960\right)$; neste caso, a dentina.

Esta técnica foi desenvolvida, originalmente, por FEIGL ${ }^{51}$, em 1958, modificada por ROSELINO, em 1983, apud ZUOLO et al. ${ }^{192}, 1987$, e adaptada para o experimento em dentina por PÉCORA ${ }^{122}$, em 1985.

Nesta, o cobre, substância indicadora, é revelado pelo ácido rubeânico no interior dos canalículos dentinários, resultando na formação de um complexo insolúvel, chamado de rubeanato de cobre, cuja coloração é próxima à negra.

Dentre as vantagens que justificaram a adoção deste método está o fato do íon cobre apresentar tamanho molecular bem menor que as moléculas dos corantes, sem os efeitos nocivos à saúde e ao meio ambiente, causados pelo uso de radioisótopos. Além disso, permite uma alta reprodutibilidade, o que possibilita a comparação dos resultados obtidos (RIBEIRO $\left.{ }^{140}, 2001\right)$. 
Vários estudos têm sido desenvolvidos utilizando-se desta técnica ou variações da mesma (PÉCORA ${ }^{122}$, 1985, PÉCORA et al. ${ }^{125}, 1987$, ZUOLO et al. ${ }^{192}$, 1987, SILVA et al. ${ }^{158}, 1990$, PÉCORA $^{123}, 1992$, PÉCORA et al. ${ }^{124}, 2000$; RIBEIRO ${ }^{140}$, 2001, BRUGNERA JÚNIOR et al. ${ }^{21}$, 2003; CARRASCO; PÉCORA; FRÖNER ${ }^{29}$, 2004).

O método original prevê a mensuração da área dentinária marcada pelo complexo rubeanato de cobre por meio de morfometria, com microscópio óptico, dotado de grade de integração. Para isso, é necessária a montagem dos fragmentos dentinários em lâminas histológicas (PÉCORA ${ }^{122}$, 1985; PÉCORA et al. ${ }^{125}, 1987$ ).

Entretanto, nesta pesquisa, optou-se pela mensuração em computador, com o auxílio do programa ImageTool 3.0.

A obtenção de imagens fotográficas digitais dos fragmentos dentinários dispensou a necessidade de confecção de lâminas. Isto tornou o processo mais rápido e, também, mais preciso, uma vez que o programa fornece a área em valores absolutos (milímetros quadrados), que, posteriormente, foram convertidos em porcentagem de penetração dos íons cobre, evidenciados pelo ácido rubeânico.

Para possibilitar a comparação dos resultados, deste experimento, com os do experimento anterior, optou-se pela utilização de raízes de incisivos centrais superiores. O estabelecimento do número de raízes em cada grupo experimental baseou-se nos trabalhos de PÉCORA ${ }^{122}$, 1985, PÉCORA et al. ${ }^{125}, 1987$, RIBEIRO ${ }^{140}, 2001$, BRUGNERA JÚNIOR et al. ${ }^{21}, 2003$.

A técnica de instrumentação, as cânulas de irrigação e o número de instrumentos empregados no preparo do canal foram os mesmos adotados no experimento para a avaliação da capacidade de limpeza dentinária, por meio da microscopia eletrônica de varredura.

Entretanto, houve necessidade de modificar a irrigação dos canais radiculares durante o preparo, substituindo a solução de hipoclorito de sódio a $2 \%$. PÉCORA ${ }^{122}$, 1985, PÉCORA et al. ${ }^{125}, 1987$, SILVA et al. ${ }^{158}, 1990$, PÉCORA ${ }^{123}, 1992$, PÉCORA et al. $^{124}$, 2000, RIBEIRO ${ }^{140}$, 2001, BRUGNERA JÚNIOR ${ }^{20}$, 2001, e BRUGNERA JÚNIOR et al. ${ }^{21}$, 2003, verificaram que as soluções de hipoclorito de sódio, independentemente das concentrações utilizadas, promovem aumento da permeabilidade dentinária em virtude da sua alta capacidade de solvência de 
matéria orgânica, apesar de não removerem, satisfatoriamente, a smear layer (McCOMB; SMITH ${ }^{101}$, 1975, YAMADA et al. ${ }^{188}$, 1983; MADER; BAUMGARTNER; PETERS $^{96}$, 1984).

Para evitar que a solução de hipoclorito de sódio alterasse a permeabilidade dentinária, influenciando, assim, nos resultados obtidos, optou-se pela substituição desta solução, durante a instrumentação dos canais radiculares.

Portanto, neste experimento, as soluções estudadas foram empregadas, ao longo de toda a instrumentação: o EGTA (isolado ou associado aos tensoativos: aniônico ou catiônico), o EDTA (controle positivo) e a água destilada (controle negativo).

Os resultados obtidos nesta etapa da pesquisa evidenciaram que, em relação à capacidade de promover o aumento da permeabilidade dentinária, as soluções irrigantes estudadas puderam ser agrupadas em ordem decrescente do seguinte modo: EDTA (controle positivo), EGTA-T, EGTA-C, EGTA, água destilada (controle negativo).

A água destilada foi utilizada como solução controle negativo, pois não interfere na permeabilidade da dentina (MARSHALL; MASSLER; DUTE ${ }^{98}, 1960$, PÉCORA ${ }^{122}$, 1985, PÉCORA ${ }^{123}, 1992$, PÉCORA et al. ${ }^{124}, 2000$, BRUGNERA JÚNIOR ${ }^{20}, 2001$, RIBEIRO ${ }^{140}, 2001$, BRUGNERA JÚNIOR et al. ${ }^{21}$, 2003). O grupo tratado com esta solução apresentou os piores valores de permeabilidade, uma vez que a mesma é desprovida de capacidade de remover a smear layer, resultante da instrumentação. Os túbulos dentinários, estando obstruídos, dificultaram a penetração dos íons cobre na dentina, justificando estes resultados.

A solução que melhor promoveu o aumento da permeabilidade dentinária foi o EDTA a $17 \%$ (controle positivo), o que corrobora os achados de PÉCORA ${ }^{122}, 1985$, e PÉCORA et al. ${ }^{125}, 1987$.

As soluções quelantes, como a solução de EDTA e EGTA, utilizadas neste estudo, por serem capazes de remover a smear layer, promoveram aumento desta permeabilidade, por tornarem os túbulos dentinários desobstruídos, o que permitiu uma maior difusão dos íons cobre na dentina $\left(P^{\prime} C_{C O R A}{ }^{122}, 1985\right.$, RIBEIRO $^{140}$, 2001). 
Outro fator que poderia ter influenciado a permeabilidade, a favor da solução de EDTA, foi observado por ÇALT; SERPER ${ }^{24}$, em 2000, e VISWANATH; HEGDE; MUNSHI ${ }^{179}$, em 2003. Estes autores verificaram que a solução de EDTA promove a erosão da dentina peritubular, o que poderia resultar na dilatação dos túbulos dentinários, tornando-os mais permeáveis, fato não observado com a solução de EGTA em seus estudos. Entretanto, esta erosão dentinária não foi observada nas fotomicrografias, realizadas por meio de microscopia eletrônica de varredura, nesta pesquisa.

Nos grupos, onde a solução de EGTA foi utilizada, isolada ou associada à tensoativos, foram observados valores intermediários de permeabilidade dentinária, estatisticamente semelhantes entre si, porém, superiores aos verificados no grupo controle negativo (água destilada).

Dentre as soluções experimentais de EGTA, somente a solução de EGTA associada ao tensoativo aniônico (EGTA-T), foi estatisticamente semelhante à solução de EDTA.

A adição de tensoativos à solução de EGTA, provavelmente, deve ter reduzido sua tensão superficial, aumentando seu poder de umectação. Entretanto, no estudo da capacidade de limpeza da superfície dentinária, por meio de microscopia eletrônica de varredura, foi demonstrado que esta potencialização do efeito quelante, só foi significativamente eficaz, para a associação EGTA-Tergensol, pelos motivos anteriormente mencionados.

Em relação aos terços radiculares, houve diferença estatisticamente significante entre os três terços estudados. A menor permeabilidade foi observada no terço apical, o que pode ser justificado pelo menor diâmetro e número de túbulos, nesta região (WHITTAKER; KNEALE ${ }^{187}$, 1979). Já o terço médio apresentou valores intermediários de permeabilidade, enquanto que o cervical apresentou os maiores valores. Estes resultados estão de acordo com os observados por PASHLEY ${ }^{118}$, em 1985.

Os resultados obtidos nas duas etapas desta pesquisa apresentaram correlação diretamente proporcional, confirmada pelo teste estatístico de Spearman. Foi observado que quanto maior a capacidade de limpeza da solução irrigante, maior a permeabilidade dentinária resultante. 
Entretanto, a alteração promovida na irrigação poderia inviabilizar a comparação dos resultados obtidos neste experimento (permeabilidade dentinária), com os resultados do experimento anterior (limpeza dentinária).

Porém, MORAES ${ }^{105}$, em 1981, avaliando a infiltração marginal de corantes em dentes instrumentados e obturados, verificou não haver diferença significante entre instrumentar o canal empregando-se uma solução quelante (EDTA) ou apenas utiliza-la ao final da instrumentação, para a limpeza final.

Já DIEP; BRAMANTE ${ }^{45}$, em 1997, avaliaram a influência do modo de aplicação de um agente quelante na limpeza das paredes dos canais radiculares e verificaram qual a forma de aplicação mais eficiente. Os autores não observaram diferença estatisticamente significante entre o uso do EDTA ao longo de toda a instrumentação e o seu uso alternado com a água destilada ou hipoclorito de sódio $1 \%$, durante a instrumentação, ou por 1 minuto após a instrumentação.

SHOVELTON ${ }^{157}$, em 1964, demonstrou que os túbulos dentinários podem alojar microrganismos, em decorrência da necrose pulpar, tornando o tratamento endodôntico mais complexo.

Desde então, tem sido uma preocupação da Endodontia, a busca de soluções e medicamentos capazes de promoverem a limpeza e descontaminação das regiões mais profundas da dentina.

Para que isto ocorra, a superfície dentinária do canal radicular deve estar limpa e permeável. Contudo, atualmente, não existe uma solução irrigadora ideal que preencha os requisitos de biocompatibilidade, solvência de matéria orgânica, efeito antimicrobiano de amplo espectro e capacidade de remoção da smear layer.

Neste estudo, a solução experimental de EGTA a 15\%, associada ao tensoativo aniônico (Tergensol), demonstrou ser uma alternativa ao uso da solução de EDTA a $17 \%$, na promoção da limpeza das paredes dos canais radiculares e no aumento da permeabilidade dentinária.

Este trabalho abre novas perspectivas para o estudo da solução de EGTA. Além da adição de um tensoativo à solução de EGTA, para aumentar sua capacidade de limpeza e a permeabilidade da dentina, sua associação com uma substância antimicrobiana como, por exemplo, a clorexidina, poderia ser 
interessante, já que as soluções quelantes atuais não apresentam uma capacidade antimicrobiana satisfatória.

Pensando de forma semelhante, em 2006, GONZÁLES-LÓPEZ et al. ${ }^{70}$ propuseram a associação da clorexidina a $1 \%$ às soluções de EDTA e ácido cítrico, visando conferir às mesmas, um poder antimicrobiano.

Desta maneira, é imprescindível que outras pesquisas sejam realizadas para que novas soluções irrigadoras sejam criadas e testadas, para que o tratamento endodôntico possa ter um índice de sucesso ainda maior. 
7 - CONCLUSÕES 


\section{7 - CONCLUSÕES}

Com base na metodologia empregada e nos resultados obtidos, pôde-se concluir que:

Tanto em relação à capacidade de limpeza da superfície dentinária das paredes dos canais radiculares instrumentados, como em relação à capacidade de promover o aumento da permeabilidade dentinária, as soluções irrigadoras estudadas puderam ser agrupadas em ordem decrescente do seguinte modo: EDTA (controle positivo), EGTA-T, EGTA-C, EGTA, Água destilada (controle negativo).

$A$ adição de tensoativos à solução de EGTA resultou em uma melhora de sua capacidade de limpeza da superfície dentinária e de sua capacidade em promover o aumento da permeabilidade da dentina.

Dentre as soluções irrigadoras experimentais testadas, apenas a solução de EGTA-T a 15\% apresentou resultados estatisticamente semelhantes à solução de EDTA a $17 \%$, tanto em relação à limpeza da superfície dentinária, quanto em relação à permeabilidade da dentina.

Em ambos os experimentos, os piores resultados foram observados no terço apical.

Houve uma correlação diretamente proporcional entre os resultados obtidos nos dois experimentos realizados: quanto maior a capacidade de limpeza promovida pela solução quelante estudada, maior a permeabilidade da dentina das paredes do canal. 
REFERÊNCIAS 


\section{REFERÊNCIAS}

1. ABBOTT, P. et al. An SEM study of the effects of different irrigation sequences and ultrasonics. Int Endod J, Oxford, v. 24, n. 6, p. 308-316, Nov. 1991.

2. AHLQUIST, M. et al. The effectiveness of manual and rotary techniques in the cleaning of root canals: a scanning electron microscopy study. Int Endod J, Oxford, v.34, n.7, p.533-537, Oct. 2002.

3. AKTENER, B.; BILKAY, U. Smear layer removal with different concentrations of EDTA-ethylenediamine mixtures. J Endod, Baltimore, v. 19, n. 5, p. 228231, May 1993.

4. ANDERSON, D. J.; RONNING, G. A. Dye diffusion in human dentine. Arch Oral Biol, Oxford, v. 7, n. 4, p. 505-512, Jul./Aug., 1962.

5. ARAUJO, T.P. Estudo comparativo da permeabilidade dentinária radicular diante da presença ou ausência de cemento, associado à avaliação da resistência que diferentes materiais para cimentação de núcleos metálicos fundidos oferecem à penetração de fluidos. 1999. 103 f. Tese (Doutorado) - Faculdade de Odontologia, Universidade de São Paulo, São Paulo.

6. ARI, H.; ERDEMIR, A.; BELLI, S. Evaluation of the effect of endodontic irrigation solutions on the microhardness and the roughness of root canal dentin. J Endod, Baltimore, v. 30, n. 11, p. 792-795, Nov. 2004

7. AUN, C. E. Avaliação através da microscopia eletrônica de varredura da limpeza da parede do canal radicular (terço apical), após o preparo químico-mecânico, tendo como fonte de variação o tipo e o número de uso dos instrumentos. 1985. 73 f. Tese (Doutorado) - Faculdade de Odontologia, Universidade de São Paulo, São Paulo.

8. AUN, C. E. Análise in vitro, através da microscopia eletrônica de varredura, da quantidade de túbulos dentinários livres da camada residual de magma no terço apical do canal radicular, após preparo químico-mecânico, variando o instrumento e seu número de uso. 1990. 
68 f. Tese (Livre Docência) - Faculdade de Odontologia, Universidade de São Paulo, São Paulo.

9. AUN, C. E.; PAIVA, J. G.; ANTONIAZZI, J. H. Avaliação, através da microscopia eletrônica de varredura, da limpeza da parede do canal radicular (terço apical), após o prepare químico-mecânico, tendo como fonte de variação o tipo e o número de uso de instrumentos. Rev Assoc Paul Odontol, São Paulo, v. 44, n. 1, p. 13-17, jan./fev.1990.

10. BAKER, N. A. et al. Scanning electron microscopic study of the efficacy of various irrigating solutions. J Endod, Baltimore, v. 1, n. 4, p. 127-135, Apr. 1975.

11. BARBOSA, S. V.; SAFAVI, K. E.; SPÄNGBERG, L. S. W. Influence of sodium hypochlorite on the permeability and structure of cervical human dentine. Int Endod J, Oxford, v. 27, n. 6, p. 309-312, Nov. 1994.

12. BARKHORDAR, R. A. et al. Removal of intracanal smear by doxycycline in vitro. Oral Surg Oral Med Oral Pathol, St. Louis, v. 84, n. 4, p. 420-423, Oct. 1997.

13. BAUMGARTNER, J. C. et al. A scanning electron microscopic evaluation of root canal debridement using saline, sodium hypochlorite and citric acid. J Endod, Baltimore, v. 10, n. 11, p. 525-530, Nov. 1984.

14. BAUMGARTNER, J. C.; MADER, C. L. A scanning electron microscopic evaluation of four root canal irrigation regimens. J Endod, Baltimore, v. 13, n. 4, p. 147-157, Apr. 1987.

15. BEHREND, G. D.; CUTLER, C. W.; GUTMANN, J. L. An in vitro study of smear layer removal and microbial leakage along root-canal fillings. Int Endod J, Oxford, v. 29, n. 2, p. 99-107, Mar. 1996.

16. BELTZ, R. E.; TORABINEJAD, M.; POURESMAIL, M. Quantitative analysis of solubilizing action of MTAD, sodium hypochlorite, and EDTA on bovine pulp and dentin. J Endod, Baltimore, v. 29, n. 5, p. 334-337, May 2003.

17. BLOOMFIELD, S. F.; MILES, G. A. The antibacterial properties of sodium dichloroisocyanurate and sodium hypochlorite formulations. J Appl Bacteriol, Oxford, v. 46, n. 1, p. 65-73, Feb. 1979. 
18. BOLANOS, O. R.; JENSEN, J. R. Scanning electron microscope comparisons of the efficacy of various methods of root canal preparation. $\mathbf{J}$ Endod, Baltimore, v. 6, n. 11, p. 815-822, Nov. 1980.

19. BRANCINI, M. R.; BRAMANTE, C. M.; BERBET, A. Poder de limpeza de algumas soluções irrigadoras analisadas pelo microscópio. Rev Paul Endod, São Paulo, v. 4, n. 1/4, p. 116-124, jan./dez. 1983.

20. BRUGNERA JÚNIOR, A. Estudo da ação dos lasers Er: YAG E Nd: YAG sobre a permeabilidade da dentina das paredes dos canais radiculares instrumentados. 2001. 101 f. Tese (Doutorado) - Faculdade de Odontologia, Universidade Federal do Rio de Janeiro, Rio de Janeiro.

21. BRUGNERA JÚNIOR, A. et al. Effects of Er:YAG and Nd:YAG laser irradiation on radicular dentine permeability using different irrigating solutions. Lasers Surg Med, New York, v. 33, n. 4, p. 256-259, 2003.

22. BRZOZOWSKI, M. E. Influência da aplicação do tetrafluoreto de titânio na permeabilidade dentinária do sistema endodôntico. 2002. 137 f. Tese (Doutorado) - Faculdade de Odontologia, Universidade de São Paulo, São Paulo.

23. BYSTRÖM, A.; SUNDQVIST, G. The antibacterial action of sodium hypochlorite and EDTA in 60 cases of endodontic therapy. Int Endod J, Oxford, v. 18, n. 1, p. 35-40, Jan. 1985.

24. ÇALT, S.; SERPER, A. Smear layer removal by EGTA. J Endod, Baltimore, v. 26, n. 8, p. 459-461, Aug. 2000.

25. ÇALT, S.; SERPER, A. Time-dependent effects of EDTA on dentin structures. J Endod, Baltimore, v. 28, n. 1, p. 17-19, Jan. 2002.

26. CAMERON, J. A. The use of ultrasonic in the removal of the smear layer: a scanning electron microscope study. J Endod, Baltimore, v. 9, n. 7, p. 289292, July 1983.

27. CARDOSO, L. N. Avaliação in vitro da permeabilidade dentinária dos terços cervical, médio e apical dos canais radiculares, após instrumentação rotatória variando-se as substâncias químicas auxiliares. 2003. 126 f. Dissertação (Mestrado) - Faculdade de Odontologia, Universidade de São Paulo, São Paulo. 
28. CARINI, R. et al. Role of $\mathrm{Na}+/ \mathrm{Ca} 2+$ exchanger in preventing $\mathrm{Na}+$ overload and hepatocyte injury: opposite effects of extracellular and intracellular Ca2+ chelation. Biochem Biophys Res Commun, New York, v. 232, n. 1, p. $107-$ 110, Mar. 1997.

29. CARRASCO, L. D.; PÉCORA, J. D.; FRÖNER, I. C. In vitro assessment of dentinal permeability after the use of ultrasonic-activated irrigants in the pulp chamber before internal dental bleaching. Dent Traumatol, Copenhagen, v. 20, n. 3, p. 164-168, June 2004.

30. CHAMMAS, F.; LAGE-MARQUES, J. L. S. Análise da permeabilidade dentinária variando a renovação das substâncias químicas durante o preparo endodôntico. J Bras Endod, Curitiba, v. 5, n. 17, p. 121-125, abr./jun. 2004.

31. CHAVES, M. Avaliação, por meio de microscopia eletrônica de varredura, da presença de detritos nos canais radiculares instrumentados com os géis de clorexidina e de mamona. 2002. 90 f. Dissertação (Mestrado) Faculdade de Odontologia de Ribeirão Preto, Universidade de São Paulo, Ribeirão Preto.

32. CHOW, T. Mechanical effectiveness of root canal irrigation. J Endod, Baltimore, v. 9, n. 11, p. 475-479, Nov. 1983.

33. CIUCCHI, B.; KHETTABI, M.; HOLZ, J. The effectiveness of different endodontic irrigation procedures on the removal of the smear layer: a scanning electron microscopic study. Int Endod J, Oxford, v. 22, n. 1, p. 2128, Jan. 1989.

34. COELHO, J. B. E. O uso do ácido cítrico em endodontia. 1995. 109 f. Dissertação (Mestrado) - Faculdade de Odontologia, Universidade Federaldo Rio de Janeiro, Rio de Janeiro.

35. COHEN, S.; STEWART, G. G.; LASTER, L. L. The effects of acids, alkalies, and chelating agents on dentine permeability. Oral Surg Oral Méd Oral Pathol, St. Louis, v. 29, n. 4, p. 631-634, Apr. 1970.

36. CRUMPTON, B. J.; GOODELL, G. G.; McCLANAHAN, S. B. Effects on smear layer and debris removal with varying volumes of 17\% REDTA after rotary instrumentation. J Endod, Baltimore, v. 31, n. 7, p. 536-538, July 2005. 
37. CRUZ FILHO, A. M. Ação do EDTAC sobre a microdureza da dentina radicular, após diferentes tempos de aplicação. 1994. 86 f. Dissertação (Mestrado) - Faculdade de Odontologia, Ribeirão Preto da Universidade de São Paulo, Ribeirão Preto.

38. CRUZ FILHO, A. M. Avaliação da ação dos quelantes EDTAC, CDTA e EGTA sobre a microdureza da dentina radicular. 1998. 98 f. Tese (Doutorado) - Faculdade de Odontologia de Ribeirão Preto, Universidade de São Paulo, Ribeirão Preto.

39. CRUZ FILHO, A. M. et al. Effect of different EGTA concentrations on dentin microhardness. Braz Dent J, Ribeirão Preto, v. 13, n. 3, p. 188-190, 2002.

40. CRUZ-FILHO, A. M. et al. Evaluation of the effect of EDTAC, CDTA and EGTA on radicular dentin microhardness. J Endod, Baltimore, v. 27, n. 3, p. 183-184, Mar. 2001.

41. CURY, J. A.; BRAGOTTO, C.; VALDRIGHI, L. The desmineralizing of EDTA solutions on dentin. I. Influence of $\mathrm{pH}$. Oral Surg Oral Med Oral Pathol, St. Louis, v. 52, n. 4, p. 446-448, Oct. 1981.

42. DE DEUS, G. et al. Real-time atomic force microscopy of root dentine during demineralization when subjected to chelating agents. Int Endod J, Oxford, v. 39, n. 9, p. 683-692, Sept. 2006.

43. DEZOTTI, M. S. G.; SOUZA JÚNIOR, M. H. S.; NISHIYAMA, C. K. Avaliação da variação de $\mathrm{pH}$ e da permeabilidade da dentina cervical em dentes submetidos ao tratamento clareador. Pesqui Odontol Bras, São Paulo, v. 16, n. 3, p. 263-268, jul./set. 2002.

44. DI LENARDA, R.; CADENARO, M.; SBAIZERO, O. Effectiveness of $1 \mathrm{~mol} \mathrm{~L}^{-1}$ citric acid and 15\% EDTA irrigation on smear layer removal. Int Endod J, Oxford, v. 33, n. 1, p. 46-52, Jan. 2000.

45. DIEP, E. K.; BRAMANTE, C. M. Efeito do modo de aplicação do EDTA na limpeza das paredes dos canais radiculares. Rev FOB, Bauru, v. 5, n. 1/2, p. 1-7, jan./jun. 1997.

46. DIPPEL, H. W.; BORGGREVEN, J. M. P. M.; HOPPENBROUWERS, P. M. M. Morphology and permeability of the dentinal smear layer. J Prosthet Dent, St. Louis, v. 52, n. 5, p. 657-662, Nov. 1984. 
47. DOGAN, H.; ÇALT, S. Effects of chelating agents and sodium hypochlorite on mineral content of root dentin. J Endod, Baltimore, v. 27, n. 9, p. 578-580, Sept. 2001.

48. DRAKE, D. R. et al. Bacterial retention in canal walls in vitro: effects of smear layer. J Endod, Baltimore, v. 20, n. 2, p. 78-82, Feb. 1994.

49. FAIRBANKS, D. C. O. Avaliação da capacidade quelante do EDTA, do EDTAC e do EDTA-T pela análise da microdureza da dentina radicular. 1995. 82 f. Dissertação (Mestrado) - Faculdade de Odontologia, Universidade do Estado do Rio de Janeiro, Rio de Janeiro.

50. FEHR, F. R.; OSTBY, N. B. Effect of EDTAC and sulfuric acid on root canal dentine. Oral Surg Oral Med Oral Pathol, St. Louis, v. 16, n. 2, p. 199-205, Feb. 1963.

51. FEIGL, F. Spot test in organic analysis. Amsterdan: Elsevier, 1958, p. 8788.

52. FELLER, C. et al. Avaliação comparativa da permeabilidade dentinária radicular entre o preparo do canal efetuado manualmente e com o auxílio de ultrasom. Rev Paul Odontol, São Paulo, v. 8, n. 5, p. 2-12, set./out. 1986.

53. FOGEL, H. M.; MARSHALL, F. J.; PASHLEY, D. H. Effects of distance from the pulp and thickness on the hydraulic conductance of human radicular dentin. J Dent Res, Alexandria, v. 67, n. 11, p. 1381-1385, Nov. 1988.

54. FOGEL, H. M.; PASHLEY, D. H. Dentin permeability: effects of endodontic procedures on root slabs. J Endod, Baltimore, v. 16, n. 9, p. 442-445, Sept. 1990.

55. FOLEY, D. B. et al. Effectiveness of selected irrigants in the elimination of Bacteroides melaninogenicus from the root canal system: an in vitro study. $\mathbf{J}$ Endod, Baltimore, v. 9, n. 6, p. 236-241, June 1983.

56. FRASER, J. G.; LAWS, A. J. Chelating agents: their effect on the permeability of the root canal dentin. Oral Surg Oral Med Oral Pathol, St. Louis, v. 41, n. 4, p. 534-540, Apr. 1976.

57. FROIS, I. M. et al. Permeabilidade da dentina radicular: um novo método de avaliação. Rev Paul Endod, São Paulo, v. 4, n. 6, p. 77-83, 1981. 
58. FROMME, H. G.; GUTTZEIT, R.; RIEDEL, H. Experimentelle untersuchungen zur frage der mechanischen und chemischen. wurzelkanalaufbereitung. sozwie zur wandstandigkeit von wurzelfullungsmaterialen. Dtsch Zahnarztl Z, München, v. 25, n. 9, p. 865-876, Sept. 1970.

59. GALVAN, D. A. et al. Effect of smear layer removal on the diffusion permeability of human roots. J Endod, Baltimore, v. 20, n. 2, p. 83-86, Feb. 1994.

60. GAMBARINI, G. Shaping and cleaning the root canal system: a scanning elecron microscopic evaluation of a new instrumentation and irrigation technique. J Endod, Baltimore, v. 25, n. 12, p. 800-803, Dec. 1999.

61. GARBEROGLIO, R.; BECCE, C. Smear layer removal by root canal irrigants. Oral Surg Oral Med Oral Pathol, St. Louis, v. 78, n. 3, p. 359-367, Sept. 1994.

62. GARBEROGLIO, R.; BRÄNSTRÖM, M. Scanning electron microscopic investigation of human dentinal tubules. Arch Oral Biol, Oxford, v. 21, n. 6, p. 355-362, 1976.

63. GAVINI, G. Avaliação "in vitro" da limpeza da parede do canal radicular (terço apical), após o preparo químico-mecânico, valendo-se da microscopia eletrônica de varredura, tendo como fonte de variação a solução irrigadora e seu volume. 1992. 75 f. Dissertação (Mestrado) Faculdade de Odontologia, Universidade de São Paulo, São Paulo.

64. GAVINI, G. Análise "in vitro" da limpeza do terço apical do canal radicular, quanto a remoção do magma dentinário, à luz da microscopia eletrônica de varredura, tendo como fonte de variação o regime de irrigação e as soluções irrigantes. 1994. 110 f. Tese (Doutorado) Faculdade de Odontologia, Universidade de São Paulo, São Paulo.

65. GIARDINO, L. et al. Surface tension comparision of four common root canal irrigants and two new irrigants containing antibiotic. J Endod, Baltimore, v. 32, n. 11, p. 1091-1093, Nov. 2006.

66. GOLDBERG, F.; ABRAMOVICH, A. Analysis of the effect of EDTAC on the dentinal walls of the root canal. J Endod, Baltimore, v. 3, n. 3, p. 101-105, Mar. 1977. 
67. GOLDBERG, F.; SPIELBERG, C. The effect of EDTA and the variation of its working time analyzed with scanning electron microscopy. Oral Surg Oral Med Oral Pathol, St. Louis, v. 53, n. 1, p. 74-77, Jan. 1982.

68. GOLDMAN, L. B. et al. The efficacy of several irriganting solutions for endodontics: a scanning electron microscopic study. Oral Surg Oral Med Oral Pathol, St. Louis, v. 52, n. 2, p. 197-204, Aug. 1981.

69. GOLDMAN, M. et al. The efficacy of several endodontic irriganting solutions: a scanning electron microscopic study: part 2. J Endod, Baltimore, v. 8, n. 11, p. 487-492, Nov. 1982.

70. GONZÁLEZ-LÓPEZ, S. et al. Effect of CHX on the decalcifying effect of $10 \%$ citric acid, $20 \%$ citric acid, or $17 \%$ EDTA. J Endod, Baltimore, v. 32, n. 8, p. 781-784, Aug. 2006.

71. GRANDE, N. M. et al. Interaction between EDTA and sodium hypochrorite: a nuclear magnetic resonance analysis. J Endod, Baltimore, v. 32, n. 5, p. 460464, May 2006.

72. GUERISOLI, D. M. Z. Estudo, por meio de microscopia eletrônica de varredura, da remoção da smear layer dos canais radiculares, após a aplicação de diferentes agentes quelantes e do laser Er:YAG. 2002. $76 \mathrm{f}$.

Dissertação (Mestrado) - Faculdade de Odontologia de Ribeirão Preto, Universidade de São Paulo, Ribeirão Preto.

73. GUERISOLI, D. M. Z. et al. Evaluation of smear layer removal by EDTAC and sodium hypochlorite with ultrasonic agitation. Int Endod J, Oxford, v. 35, n. 5, p. 418-421, May 2002.

74. GUIMARÃES, L. F. L. et al. Tensão superficial de algumas soluções irrigantes dos canais radiculares. Rev Odontol USP, São Paulo, v. 2, n. 1, p. 6-9, jan./mar. 1988.

75. HAMAOKA, L.; MOURA, A. A. M. Avaliação in vitro da permeabilidade dentinária radicular, tendo como fonte de variação três diferentes tipos de corantes. Rev Odontol USP, São Paulo, v. 10, n. 1, p. 39-42, jan./mar. 1996.

76. HAMPSON, E. L.; ATKINSON, A. M. The relation between drugs used in canal therapy and the permeability of dentin. Brit Dent J, London, v. 116, n. 12, p. 546-550, June 1964. 
77. HAND, R. E.; SMITH, M. L.; HARRISON, J. W. Analysis of the effect of dilution on the necrotic tissue dissolution property of sodium hypochlorite. J Endod, Baltimore, v. 4, n. 2, p. 60-64, Feb. 1978.

78. HATA, G. et al. Effectiveness of oxidative potential water as a root canal irrigant. Int Endod J, Oxford, v. 34, n. 4, p. 308-317, June 2001.

79. HAWKINSON, R. W. et al. The smear layer and bacterial penetration of radicular dentinal tubules. J Endod, Baltimore, v. 20, n. 4, p. 196, Apr. 1994. Abstract n. 33.

80. HAZNEDAROGLU, F.; ERSEV, H. Tetracycline $\mathrm{HCl}$ solution as a root canal irrigant. J Endod, Baltimore, v. 27, n. 12, p. 738-740, Dec. 2001.

81. HÜLSMANN, M.; HECKENDORFF, M.; LENNON, A. Chelating agents in root canal treatment: mode of action and indications for their use. Int Endod J, Oxford, v. 36, n. 12, p. 810-830, Dec. 2003.

82. HÜLSMANN, M; HECKENDORFF, M. SCHAFERS, F. Comparative in-vitro evaluation of three chelator pastes. Int Endod J, Oxford, v. 35, n. 8, p. 668679, Aug. 2002.

83. JEON, I. S. et al. Smear layer production by 3 rotary reamers with different cutting blade designs in straight root canals: a scanning electron microscopic study. Oral Surg Oral Med Oral Pathol, St. Louis, v. 96, n. 5, p. 601-607, Nov. 2003.

84. KAHN, F. H.; ROSENBERG, P. A.; GLIKSBERG, J. An in vitro evaluation of the irrigating characteristics of ultrasonic and subsonic handpieces and irrigating needles and probes. J Endod, Baltimore, v. 21, n. 5, p. 277-280, May 1995.

85. KAUFMAN, A. Y. et al. New chemotherapeutic agent for root canal treatment. Oral Surg Oral Med Oral Pathol, St. Louis, v. 46, n. 2, p. 283-295, Aug. 1978.

86. KHADEMI, A.; YAZDIZADEH, M.; FEIZIANFARD, M. Determination of the minimum instrumentation size for penetration of irrigants to the apical third of root canal systems. J Endod, Baltimore, v. 32, n. 5, p. 417-420, May 2006. 
87. KOSKINEN, K. P.; STENVALL, H.; UITTO, V. J. Dissolution of bovine pulp tissue by endodontic solutions. Scand J Dent Res, Copenhagen, v. 88, n. 5, p. 406-411, Oct. 1980.

88. KUM, K. Y. et al. Smear layer production of K3 and ProFile Ni-Ti rotary instruments in curved root canals: a comparative SEM study. Oral Surg Oral Med Oral Pathol, St. Louis, v. 101, n. 4, p. 536-541, Apr. 2006.

89. LAMERS, A. C.; VAN MULLEM, P. J.; SIMON, M. Tissue reaction to sodium hypochlorite and iodine potassium iodide under clinical conditions in monkey teeth. J Endod, Baltimore, v. 6, n. 10, p. 788-792, Oct. 1980.

90. LEONARDO, M. R. Preparo biomecânico dos canais radiculares. In: LEONARDO, M. R.; LEAL, J. M. Endodontia: tratamento de canais radiculares. $3^{a}$ ed. São Paulo: Panamericana, 1998. Cap. 15, p. 333-358.

91. LIM, T. et al. Light and Scanning electron microscopic evaluation of Glyde File Prep in smear layer removal. Int Endod J, Oxford, v. 36, n. 5, p. 336-343, May 2003.

92. LIOLIOS, E. et al. The effectiveness of three irrigating solution on root canal cleaning after hand and mechanical preparation. Int Endod J, Oxford, v. 30, n. 1, p. 51-57, Jan. 1997.

93. LISON, L. Histochimie et cytochimie animals: principles et métodes. Paris: Gauthier-Vilars, 1960. p. 51.

94. LOPES, H.P.; SIQUEIRA JR, J.F.; ELIAS, C.N. Substâncias químicas empregadas no preparo dos canais radiculares. In: LOPES, H.P.; SIQUEIRA JR, J.F. Endodontia: biologia e técnica. $2^{\mathrm{a}}$ ed. Rio de Janeiro: Guanabarakoogan, 2004. Cap. 18, p. 535-579.

95. LOVIK, G. et al. C1qRp elicits a Ca++ response in rat NK cells but does not influence NK-mediated cytotoxicity. Scand J Immunol, Oxford, v. 53, n. 4, p. 410-415, Apr. 2001.

96. MADER, C. L.; BAUMGARTNER, J. C.; PETERS, D. D. Scanning electron microscopic investigation of the smeared layer on root canal walls. J Endod, Baltimore, v. 10, n. 10, p. 477-483, Oct. 1984.

97. MAIA, S. M. A. S. Avaliação do uso de hipoclorito de sódio, ácido cítrico e ácido diamino tetracético (EDTA) na remoção da camada residual de 
dentina durante a instrumentação do canal radicular: estudo "in vitro". 1991. 59 f. Dissertação (Mestrado). Faculdade de Odontologia de Pernambuco, Fundaçäo de Ensino Superior de Pernambuco, Camarajibe.

98. MARSHALL, J. F.; MASSLER, M.; DUTE, H. L. Effects of endodontic treatment on permeability of root dentine. Oral Surg Oral Med Oral Pathol, St. Louis, v. 13, n. 2, p. 208-223, Feb. 1960.

99. MARTIN, H.; LASALA, A.; MICHANOWICZ, A. Permeability of the apical third of the root to drugs used in endodontic therapy: na in vitro study. $\mathbf{J}$ Oral Ther Phamacol, Baltimore, v. 4, n. 6, p. 451-455, May 1968.

100. MAYER, B. E.; PETERS, O. A.; BARBAKOW, F. Effects of rotary instruments and ultrasonic irrigation on debris and smear layer scores: a scanning electron microscopic study. Int Endod J, Oxford, v. 35, n. 7, p. 582-589, July 2002.

101. McCOMB, D.; SMITH, D. C. A preliminary scanning electron microscopic study of root canals after endodontic procedures. J Endod, Baltimore, v. 1, n. 7, p. 238-242, July 1975.

102. McCOMB, D.; SMITH, D. C.; BEAGRIE, G. S. The results of in vivo endodontic chemomechanical instrumentation - A scanning electron microscopic study. J Brit Endod Soc, London, v. 9, n. 1, p. 11-18, Jan. 1976.

103. MOODNIK, R. M. et al. Efficacy of biomechanical instrumentation: a scanning electron microscopic study. J Endod, Baltimore, v. 2, n. 9, p. 261-266, Sept. 1976.

104. MOORER, W. R.; WESSELINK, P. R. Factors promoting the tissue dissolving capability of sodium hypochlorite. Int Endod J, Oxford, v. 15, n. 4, p. 187-196, Oct. 1982.

105. MORAES, I.G. Infiltração marginal nas obturações de canais radiculares em função de agentes irrigadores e cimentos obturadores. 1981, 114 f. Dissertação (Mestrado) - Faculdade de Odontologia de Bauru, Universidade de São Paulo, Bauru.

106. MOSS, H. D.; ALLEMANG, J. D.; JOHNSON, J. D. Philosophies and practices regarding the management of endodontic smear layer: results from two surveys. J Endod, Baltimore, v. 27, n. 8, p. 537-539, Aug. 2001. 
107. MOURA, A. A. M.; PAIVA, J. G. Análise "in vitro" da permeabilidade dentinária radicular quando do emprego de instrumentos endodônticos, tendo como fonte de variação o instrumento e o número de uso: contribuição para o estudo. Rev Odont USP, São Paulo, v. 3, n. 1, p. 262-270, jan./mar. 1989.

108. MOURA, A. A. M. et al. Análise in vitro da permeabilidade dentinária radicular em dentes instrumentados com e sem uso de EDTAC. Rev Paul Odontol, São Paulo, v. 10, n. 6, p. 18-24, nov./dez. 1988.

109. NAKASHIMA, K; TERATA, R. Effect of $\mathrm{pH}$ modified EDTA solution to the properties of dentin. J. Endod., Baltimore, v. 31, n. 1, p. 47-49, Jan. 2005.

110. NANDINI, S.; VELMURUGAN, N.; KANDASWAMY, D. Removal efficiency of calcium hydroxide intracanal medicament with two calcium chelators: volumetrical analysis using spiral CT - an in vitro study. J Endod, Baltimore, v. 32, n. 11, p. 1097-1101, Nov. 2006.

111. NAUMOVICH, D. B. Surface tension and of drugs in root canal therapy. Oral Surg Oral Med Oral Pathol, St. Louis, v. 16, p. 965-968, Aug. 1963.

112. NIKIFORUK, G.; SREEBNY, L. Demineralization of hard tissues by organic chelating agents at neutral pH. J Dent Res, Alexandria, v. 32, n. 6, p. 859867, Dec. 1953.

113. NÓRA, M. B. et al. Avaliação da permeabilidade dentinária em dentes submetidos a reintervenção endodôntica quando obturados com diferentes materiais. J Bras Endod, Curitiba, v. 4, n. 14, p. 214-217, jul./set. 2003.

114. O'CONNELL, M. et al. A comparative study of smear layer removal using different salts of EDTA. J Endod, Baltimore, v. 26, n. 12, p. 739-743, Dec. 2000.

115. ØSTBY, B. N. Chelation in root canal therapy. Ethylenediamine tretra-acetic acid for cleasing and widening of root canals. Odont Tidskrift, Goteborg, v. 65, n. 2, p. 3-11, 1957.

116. ØSTBY, B. N. Seis anõs de experiência clinica y experimental con el acido etileno-diamino tetra-acetico (EDTA) como coadjuvante en la terapia de los conductos radiculares. Rev Assoc Odontol Argent, Buenos Aires, v. 50, n.1, p. 75-95, Feb. 1962. 
117. PAIVA, J. G.; ANTONIAZZI, J. H. Fase de preparo do canal radicular. In: Endodontia, bases para a prática clínica. $2^{\mathrm{a}}$ ed. São Paulo: Artes Médicas, 1988. p. 501-629.

118. PASHLEY, D. H. Dentin-predentin complex: physiological overview. J Dent Res, Alexandria, v. 64, p. 613-620, Apr. 1985. Special issue.

119. PASHLEY, D. H. Smear layer: overview of structure and function. Proc Finn Dent Soc, Helsinki, v. 88, p. 215-224, 1992. Supplement 1.

120. PASHLEY, D. H. et al. Comparision of in vitro and in vivo dog dentin permeability. J Dent Res, Alexandria, v. 60, n. 3, p. 763-768, Mar. 1981.

121. PATTERSON, S. A. In vivo and in vitro studies of the effect of disodium salt of ethylenediamine tetra-acetate on human dentine and its endodontic implications. Oral Surg Oral Med Oral Pathol, St. Louis, v. 16, n. 1, p. 83103, Jan. 1963.

122. PÉCORA, J. D. Contribuição ao estudo da permeabilidade dentinária radicular. Apresentação de um método histoquímico e análise morfométrica. 1985. 110 f. Dissertação (Mestrado) - Faculdade de Odontologia de Ribeirão Preto, Universidade de São Paulo, Ribeirão Preto.

123. PÉCORA J. D. Efeito das soluções de Dakin e de EDTA, isoladas, alternadas e misturadas, sobre a permeabilidade da dentina radicular. 1992. 147 f. Tese (Livre-Docência) - Faculdade de Odontologia de Ribeirão Preto, Universidade de São Paulo, Ribeirão Preto.

124. PECORA, J. D. et al. Evaluation of dentin root canal permeability after instrumentation and Er:YAG laser application. Laser Surg Med, New York, v. 26, n. 3, p. 277-281, 2000.

125. PÉCORA, J. D. et al. Presentation of a histochemical method for the study of root dentine permeability. Rev Odont USP, São Paulo, v. 1, n. 2, p. 3-9, abr./jun.1987.

126. PÉCORA, J. D. et al. Capacidade de umectação dos tensoativos (aniônicos, catiônicos e anfóteros). Teste in vitro. RBO, Rio de Janeiro, v. 45, n. 1, p. 2225, jan./fev.1988. 
127. PÉCORA, J. D. et al. Apresentação de um método histoquímico para revelar a ação quelante do EDTA na dentina radicular. Rev Assoc Paul Cirurg Dent, São Paulo, v. 45, n. 5, p. 263-265, set./out.1990.

128. PEREZ, F.; CALAS, P.; ROCHD, T. Effect of dentin treatment on in vitro root tubule bacterial invasion. Oral Surg Oral Med Oral Pathol, St. Louis, v. 82, n. 4, p. 446-451, Oct. 1996.

129. PEREZ, F.; ROQUEYROL-POURCEL, N. Effect of a low-concentration solution on root canal walls: a scanning electron microscopic study. Oral Surg Oral Med Oral Pathol, St. Louis, v. 99, n. 3, p. 383-387, Mar. 2005.

130. PÉREZ-HEREDIA, M.; FERRER-LUQUE, C. M.; GONZÁLEZ-RODRÍGUEZ, M. P. The effectiveness of different acid irrigating solutions in root canal cleaning after hand and rotary instrumentation. J Endod, Baltimore, v. 32, n. 10, p. 993-997, Oct. 2006.

131. PETERS, O. A.; BARBAKOW, F. Effects of irrigation on debris and smear layer on canal walls prepared by two rotary techniques: a scanning electron microscopic study. J Endod, Baltimore, v. 26, n. 1, p. 6-10, Jan. 2000.

132. POLO, I. Estudo in vitro da ação do gel Carisolv ${ }^{\mathrm{TM}}$ sobre a espectofotometria da coroa dental e permeabilidade dentinária, quando utilizado na terapia endodôntica. 2002. 181 f. Dissertação (Mestrado) Faculdade de Odontologia, Universidade de São Paulo, São Paulo.

133. PROKOPOWITSCH, I. Análise "in vitro" da permeabilidade dentinária radicular do terço apical, tendo como fonte de variação a substância química auxiliar da instrumentação (contribuição para o estudo). 1988. 65 f. Dissertação (Mestrado) - Faculdade de Odontologia, Universidade de São Paulo, São Paulo.

134. PROKOPOWITSCH, I. Influência do uso do hidróxido de cálcio como medicação intracanal na permeabilidade e limpeza dentinária radicular em dentes portadores de rizogênese incompleta (estudo in vitro). 1994. 123 f. Tese (Doutorado) - Faculdade de Odontologia, Universidade de São Paulo, São Paulo.

135. PROKOPOWITSCH, I.; MOURA, A. A. M.; MUENCH, A. Análise "in vitro" da permeabilidade dentinária radicular do terço apical, tendo como fonte de 
variação a substância química auxiliar da instrumentação. Rev Odont USP, São Paulo, v. 3, n. 2, p. 345-353, abr./jun. 1989.

136. PUAPICHARTDUMRONG, P.; IKEDA, H.; SUDA, H. Influence of the pulpal components on human dentine permeability in vitro. Int Endod J, Oxford, v. 38, n. 3, p. 152-159, Mar. 2005.

137. QING, Y. et al. Cleaning efficacy and dentin micro-hardness after root canal irrigation with a strong acid eletrolitic water. J Endod, Baltimore, v. 32, n. 11, p. 1102-1106, Nov. 2006.

138. RALDI, D. P.; LAGE MARQUES, J. L. In vitro effects of the interaction between irrigating solutions, intracanal medication and Er:YAG laser in dentin permeability of the endodontic system. Pesqui Odontol Bras, São Paulo, v. 17 , n. 3, p. 278-285, jul./set. 2003.

139. RAM, Z. Effectiveness of root canal irrigation. Oral Surg Oral Med Oral Pathol, St. Louis, v. 44, n. 2, p. 306-312, Aug. 1977.

140. RIBEIRO, R. G. Estudo da permeabilidade dentinária das paredes dos canais radiculares instrumentados com diferentes soluções irrigantes, associadas ou não à irradiação de laser Er:YAG. 2001. 100 f. Dissertação (Mestrado) - Faculdade de Odontologia de Ribeirão Preto, Universidade de São Paulo, Ribeirão Preto.

141. ROBAZZA, C. R. C. Contribuição para o estudo in vitro da permeabilidade dentinária radicular, quando do emprego de algumas substâncias de uso endodôntico. 1973. 45 f. Tese (Doutorado) - Faculdade de Odontologia de Ribeirão Preto, Universidade de São Paulo, Ribeirão Preto.

142. ROBAZZA, C. R. et al. Avaliação da permeabilidade dentinária radicular apical, segundo a quantidade de instrumentos empregados durante o preparo químico-mecânico. RBO, Rio de Janeiro, v. 4, n. 1, p. 21-25, jan./fev. 1987.

143. SABINS, R. A.; JOHNSON, J. D.; HELLSTEIN, J. W. A comparison of the cleaning efficacy of short-term sonic and ultrasonic passive irrigation after hand instrumentation in molar root canals. J Endod, Baltimore, v. 29, n. 10, p. 674-678, Oct. 2003.

144. SAQUY, P. C. Avaliação da capacidade quelante do EDTA e da associação EDTA mais solução de Dakin, por métodos químicos e pela 
análise da microdureza da dentina. 1991. 90 f. Tese (Doutorado) Faculdade de Odontologia de Ribeirão Preto, Universidade de São Paulo, Ribeirão Preto.

145. SCELZA, M. F. Z. Análise pela microscopia eletrônica de varredura da limpeza das paredes dos canais radiculares segundo as substâncias irrigadoras de acordo com três diferentes técnicas. 1998. 92 f. Tese (Doutorado) - Faculdade de Odontologia, Universidade de São Paulo, São Paulo.

146. SCELZA, M. F. Z.; ANTONIAZZI, J.; SCELZA, P. Efficacy of final irrigation - a scanning electron microscopic evaluation. J Endod, Baltimore, v. 26, n. 6, p. 355-358, June 2000.

147. SCELZA, M. F. Z. et al. Effect of three different time periods of irrigation with EDTA-T, EDTA, and citric acid on smear layer removal. Oral Surg Oral Med Oral Pathol, St. Louis, v. 98, n. 4, p. 499-503, Oct. 2004.

148. SCELZA, M. F. Z.; TEIXEIRA, A. M.; SCELZA, P. Decalcifying effect of EDTA-T, $10 \%$ citric acid, and 17\% EDTA on root canal dentin. Oral Surg Oral Med Oral Pathol, St. Louis, v. 95, n. 2, p. 234-236, Feb. 2003.

149. SCHAFER, E.; ZAPKE, K. A comparative scanning electron microscopic investigation of the efficacy of manual and automated instumentation of root canals. J Endod, Baltimore, v. 26, n. 11, p. 660-664, Nov. 2000.

150. SCHMALZ, G. et al. Permeability characteristics of bovine and human dentin under different pretreatment conditions. J Endod, Baltimore, v. 27, n. 1, p. 2330, Jan. 2001.

151. SCHMID, R. W.; REILLEY, C. N. New complexion for titration of calcium in the presence of magnesium. Anal Chem., Washington, v. 29, n. 2, p. 264-268, 1957.

152. SEN, B. H.; WESSELINK, P. R.; TÜRKÜN, M. The smear layer: a phenomenon in root canal therapy. Int Endod J, Oxford, v. 28, n. 3, p. 141148, May 1995.

153. SERAFINO, C. et al. Surface debris of canal walls after post space preparationin endodontically treated teeth: a scanning electron microscopic 
study. Oral Surg Oral Med Oral Pathol, St. Louis, v. 97, n. 3, p. 381-387, Mar. 2004.

154. SERPER, A.; ÇALT, S. The demineralizing effects of EDTA at different concentrations and pH. J Endod, Baltimore, v. 28, n. 7, p. 501-502, July 2002.

155. SETLOCK, J. et al. Evaluation of canal cleanliness and smear layer removal after the use of the Quantec-E irrigation system and syringe: a comparative scanning electron microscope study. Oral Surg Oral Med Oral Pathol, St. Louis, v. 96, n. 5, p. 614-617, Nov. 2003.

156. SHIH, M.; MARSHALL, F. J.; ROSEN, S. The bactericidal efficiency of sodium hypochlorite as an endodontic irrigant. Oral Surg Oral Med Oral Pathol, St. Louis, v. 29, n. 4, p. 613-619, Apr. 1970.

157. SHOVELTON, D. S. The presence and distribution of micro-organisms within non-vital teeth. Brit Dent J, London, v. 117, n. 3, p. 101-107, Aug. 1964.

158. SILVA, R. G. et al. Avaliação da permeabilidade dentinária radicular após a instrumentação manual e ultra-sônica, utilizando um método histoquímico. Rev Assoc Paul Cir Dent, São Paulo, v. 44, n. 3, p. 157-161, maio/jun. 1990.

159. SKELTON MACEDO, M. C. Comparação de diferentes métodos de leitura aplicados à infiltração de corante em dentina humana. 2003. 83 f. Tese (Doutorado) - Faculdade de Odontologia, Universidade de São Paulo, São Paulo.

160. SOARES, A. B.; SOUSA, S. M. G. Avaliação da biocompatibilidade do EDTA, EGTA e ácido cítrico em tecido subcutãneo de ratos. Rev Odonto Ciência, Porto Alegre, v. 18, n. 39, p. 17-22, jan./mar. 2003.

161. SOUSA-NETO, M. D. et al. Evaluation of the effect of EDTA, EGTA and CDTA on dentin adhesiveness and microleakage with different root canal sealers. Braz Dent J, Ribeirão Preto, v. 13, n. 2, p. 123-128, 2002.

162. SOUZA, R. E. et al. Avaliação da remoção de smear layer do canal radicular usando EDTA 17\%, CDTA 1\% e EGTA 1\%. Rev. Odonto Ciência, Porto Alegre, v. 18, n. 40, p. 112-116, abr./jun. 2003.

163. SOUZA, S. M. G. Avaliação da biocompatibilidade do EDTA, EGTA e ácido cítrico pela técnica de exudação de corantes vitais. 1999. 80 f. Tese 
(Doutorado) - Faculdade de Odontologia de Bauru, Universidade de São Paulo, Bauru.

164. SOUZA, S. M. G. et al. Quelantes em endodontia. RBO, Rio de Janeiro, v. 56, n. 1, p. 30-33, jan./fev. 1999.

165. STEWART, G. G.; KAPSIMALAS, P.; RAPPAPORT, H. R. EDTA and urea peroxide for root canal preparation. J Am Dent Assoc, Chicago, v. 78, n. 2, p. 335-338, Feb. 1969.

166. TAKEDA, F. H. et al. Efficacy of Er:YAG laser irradiation in removing debris and smear layer on root canal walls. J Endod, Baltimore, v. 24, n. 8, p. 548551, Aug. 1998.

167. TAKEDA, F. H. et al. A comparative study of the removal of smear layer by three endodontic irrigants and two types of laser. Int Endod J, Oxford, v. 32, n. 1, p. 32-39, Jan. 1999.

168. TAO, L; ANDERSON, R. W.; PASHLEY, D.H. Effect of endodontic procedures on root dentin permeability. J Endod, Baltimore, v. 17, n. 12, p. 583-588, Dec. 1991.

169. TASMAN, F. et al. surface tension of root canal irrigants. J Endod, Baltimore, v. 26 , n. 10 , p. 586-587, Oct. 2000.

170. TAY, F. R. et al. Ultrastructure of smear layer-covered intraradicular dentin after irrigation with Biopure MTAD. J Endod, Baltimore, v. 32, n. 3, p. 218221, Mar. 2006.

171. TEIXEIRA, C. S.; FELIPPE, C. S.; FELIPPE, W. T. The effect of application time of EDTA and $\mathrm{NaOCl}$ on intracanal smear layer removal: na SEM analysis. Int Endod J, Oxford, v. 38, n. 5, p. 285-290, May 2005.

172. THÉ, S. D. The solvent action of sodium hypochlorite on fixed and unfixed necrotic tissue. Oral Surg Oral Med Oral Pathol, St. Louis, v. 47, n. 6, p. 558561, June 1979.

173. THÉ, S. D.; MALTHA, J. C.; PLASSCHAERT, A. J. M. Reactions of guinea pig subcutaneous connective tissue following exposure to sodium hypochlorite. Oral Surg Oral Med Oral Pathol, St. Louis, v. 49, n. 5, p. 460-466, May 1980.

174. TIDMARSH, B. Acid cleansed and resin sealed root canals. J Endod, Baltimore, v. 4, n. 4, p. 117-121, Apr. 1978. 
175. TIMPAWAT, S.; VONGSAVAN, N.; MESSER, H. H. Effect of removal of smear layer on apical microleakage. J Endod, Baltimore, v. 27, n. 5, p. 351-353, May 2001.

176. TORABINEJAD, M. et al. Clinical implications of the smear layer in endodontics: a review. Oral Surg Oral Med Oral Pathol, St. Louis, v. 94, n. 6, p. 658-666, Dec. 2002.

177. TORABINEJAD, M. et al. A new solution for the removal of the smear layer. $\mathbf{J}$ Endod, Baltimore, v. 29, n. 3, p. 170-175, Mar. 2003.

178. VIEGAS, A. P. K. et al. MEV da parede de dentina frente ao uso do hipoclorito de sódio isolado, associado ao EDTA ou ao Gyde File Prep. J Bras Endod, Curitiba, v. 3, n. 11, p. 293-299, out./dez. 2002.

179. VISWANATH, D.; HEGDE, A. M.; MUNSHI, A. K. The removal of the smear layer using EGTA: a scanning electron microscopic study. J Clin Pediatr Dent, Birminghan, v. 28, n. 1, p. 69-74, Fall 2003.

180. WACH, E. C.; HAUPTFUEHRER, J. D.; KESEL, R. G. Endodontic significance of the penetration of S35-labeled penicillin in extracted human teeth. Oral Surg Oral Med Oral Pathol, St. Louis, v. 8, n. 6, p. 639-648, June 1955.

181. WAINWRIGHT, W. W.; BELGOROD, H. H. Time studies of the penetration of extracted human teeth by radioactive nicotinamide, urea, thiourea and acetamide. II. Penetration of dentin from the pulp chamber. J Dent Res, Alexandria, v. 34, n. 1, p. 28-37, Feb. 1955.

182. WANDELT, S. Eine kritische betrachtung zur aufbereitung von wurzelkanälen mit komplexibildnern. Dtsch Zahnarztl Z, München, v. 20, p. 621-626, June 1965.

183. WAYMAN, B. E. et al. Citric and latic acids as root canal irrigants in vitro. J Endod, Chicago, v. 5, n. 9, p. 258-265, Sept. 1979.

184. WEINREB, M. M.; MEIER, E. The relative efficiency of EDTA, sulfuric acid, and mechanical instrumentation in the enlargement of root canals. Oral Surg Oral Med Oral Pathol, St. Louis, v. 19, n. 2, p. 247-252, Feb. 1965.

185. WHITE, R. R.; GOLDMAN, M.; LIN, P. S. The influence of the smeared layer upon dentinal tubule penetration by plastic filling materials. J Endod, Baltimore, v. 10, n. 12, p. 558-562, Dec. 1984. 
186. WHITE, R. R.; GOLDMAN, M.; LIN, P. S. The influence of the smeared layer upon dentinal tubule penetration by endodontic filling materials.Part II. J Endod, Baltimore, v. 13, n. 8, p. 369-374, Aug. 1987.

187. WHITTAKER, D. K.; KNEALE, M. J. The dentine-predentine interface in human teeth. A scanning electron microscopy study. Brit Dent J, London, v. 146, n. 2, p. 43-46, Jan. 1979.

188. YAMADA, R. S. et al. A scanning electron microscopic comparision of a high volume final flush with several irrigating solutions. Part 3. J Endod, Baltimore, v. 9, n. 4, p. 137-142, Apr. 1983.

189. ZEHNDER, M. Root canal irrgants. J Endod, Baltimore, v. 32, n. 5, p. 389398, May 2006.

190. ZEHNDER, M. et al. Reducing surface tension in endodontic chelator solutions has no effect on their ability to remove calcium from instrumented root canals. J Endod, Baltimore, v. 31, n. 8, p. 590-592, Aug. 2005.

191. ZEHNDER, M. et al. Chelation in root canal therapy reconsidered. J Endod, Baltimore, v. 31, n. 11, p. 817-820, Nov. 2005.

192. ZUOLO, M. et al. Ação do EDTA e suas associações com tensoativos na permeabilidade da dentina radicular. Rev Odont USP, São Paulo, v. 1, n. 4, p. 18-23, out./dez. 1987. 
ABSTRACT 


\section{ABSTRACT \\ EVALUATION OF THE ROOT CANAL WALLS CLEANNESS AND DENTIN PERMEABILITY, AFTER THE USE OF THE EGTA SOLUTION ISOLATED OR ASSOCIATED WITH TENSOACTIVES}

The objective was to evaluate the root canal dentin cleanness and the dentin permeability, after the use of the EGTA solution isolated or in association with tensoactives. For the analysis of the dentin cleanness capacity, 25 human upper central incisors were used, prepared by the step-back technique with $\mathrm{K}$ type files and irrigated with $2 \%$ sodium hypoclorite. Then, the root canals were irrigated for 5 minutes, with $10 \mathrm{ml}$ of the following solutions: Group 1 - distilled water (negative control); Group 2 - 15\% EGTA; Group 3 - 15\% EGTA-C; Group 4 - 15\% EGTA-T; Group $5-17 \%$ EDTA (positive control). Soon afterwards, the root canals were irrigated with $10 \mathrm{ml}$ of distilled water and dryed with paper points. The roots were fractured longitudinally and prepared for scanning electronic microscopy. A digitally manufactured grid was superposed to the obtained digital photomicrographs of the cervical, middle and apical thirds of each specimen of the experimental groups. That allowed the calculation of the cleanness percentage of the root canals dentinal surface by counting the number of clean quadrants. For the evaluation of the dentin permeability, 25 roots of human upper central incisors were prepared with the following irrigating solutions: Group 1 - distilled water (negative control); Group 2 15\% EGTA; Group 3 - 15\% EGTA-C; Group 4 - 15\% EGTA-T; Group 5 - 17\% EDTA (positive control). During instrumentation, at each instrument change, the root canals were irrigated with $3 \mathrm{ml}$ of the studied solution. After instrumentation, the root canals were irrigated with $10 \mathrm{ml}$ of distilled water and dryed. The external surface of the roots was made waterproof, except for the apex and the cervical surface. Then, the roots were immersed in copper sulfate and, later, in rubeanic acid, both under vacuous condition. Fragments of the cervical, middle and apical thirds were obtained through transverse cuts of the roots of each experimental group. These fragments were 
photographed, and the area of penetration of the copper ions into the dentine, evidenced by its reaction with the rubeanic acid (black coloration), was mensured in the computer (ImageTool 3.0 software). That made possible to quantify the dentin permeability. The data obtained in both experiments were submitted to the statistical analysis. The results showed that the studied solutions could be arranged in a decreasing order of dentin cleanness capacity and dentin permeability: EDTA, EGTAT, EGTA-C, EGTA, distilled Water. The tensoactive addition to the EGTA solution resulted in an improvement of its dentin cleanness capacity and an increase of the dentin permeability. Only the 15\% EGTA-T experimental solution presented statistical similar results as the ones presented by the 17\% EDTA solution $(p>0,05)$ (for both the dentin cleanness, and the dentin permeability). There was a directly proportional correlation among the results obtained in the two accomplished experiments: the greater the cleanness capacity promoted by the studied solution, the greater the dentin permeability of the root canal walls.

Keywords: Irrigating solutions. Dentin cleanness. Dentin permeability. Endodontics. 